\title{
Economic Impacts of Oil Spills: Spill Unit Costs for Tankers, Pipelines, Refineries, and Offshore Facilities
}

\author{
Prepared for:
}

\author{
U.S. Department of Energy \\ Office of Domestic and International Energy Policy \\ Contract No. DE-AC01-93EP79129 \\ Task Assignment No. 1
}

Prepared by:

Advanced Resources International, Inc.

\section{October 15, 1993}

DISCLAIMER

This report was prepared as an account of work sponsored by an agency of the United States Government. Neither the United States Gnvernment nor any agency thereof, nor any of their employees, makes any warranty, express or implied, or assumes any legal liability or responsibility for the accuracy, completeness, or usefulness of any information, apparatus, product, or process disclosed, or represents that its use would not infringe privately owned rights. Reference herein to any specific commercial product, process, or service by trade name, trademark, manufacturer, or otherwise does not necessarily constitute or imply its endorsement, recominendation, or favoring by the United States Government or any agency thereof. The views and cpitions of authors expressed herein do not necessarily state or reflect those of the United States Government or any agency thereof. 


\section{Table of Contents}

Page

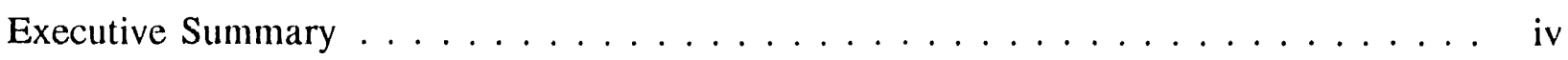

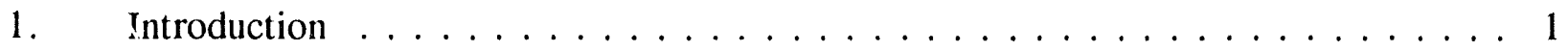

1.1 Overview and Purpose of Study $\ldots \ldots \ldots \ldots \ldots \ldots \ldots \ldots$

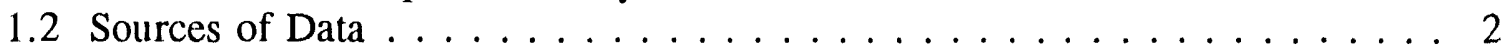

1.3 Methodology . . . . . . . . . . . . . . . . 2

2. Natural Resource Damage Assessment Methodologies $\ldots \ldots \ldots \ldots \ldots$

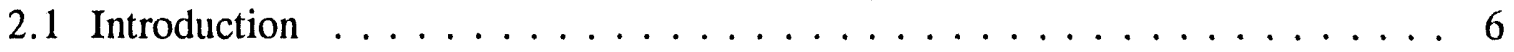

2.2 Market-Based Methods . . . . . . . . . . . . . . . 6

2.3 Revealed Preference Methods . . . . . . . . . . . . . . 6

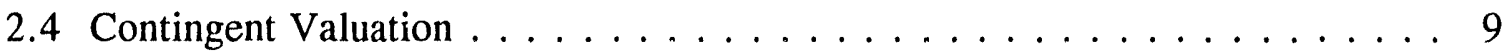

3. Development of Natural Resource Damage Assessment Regulations . . . . . . . 16

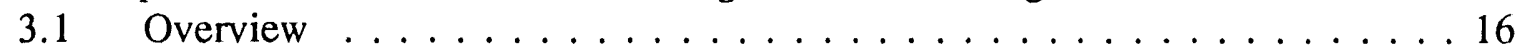

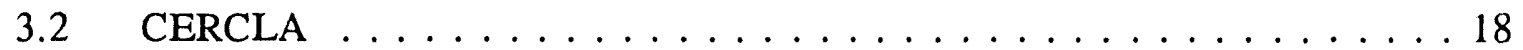

3.3 DOI Natural Resource Damage Regulations . . . . . . . . . . . . 18

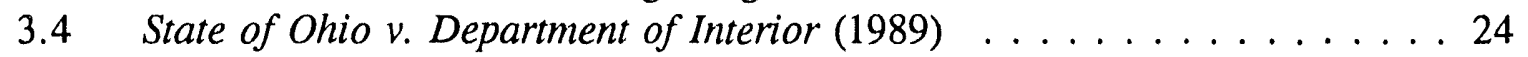

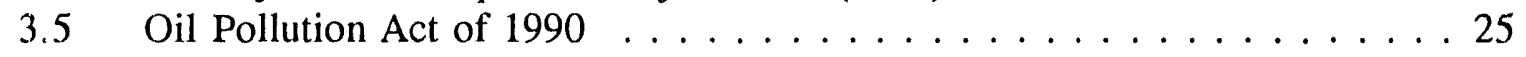

3.6 NOAA Regulations (Proposed) . . . . . . . . . . . . . . . . . . . 29

3.7 State of Washington Oil Spill Compensation Schedule . . . . . . . . . . 31

3.8 Florida Natural Resource Damage Compensation Schedule . . . . . . . . 35

4. Critical Analysis of Natural Resource Damage Assessments . . . . . . . . . . 37

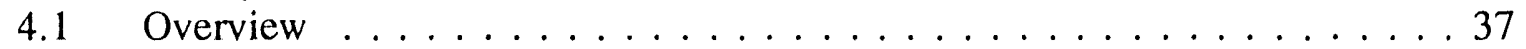

4.2 Tanker Spills . . . . . . . . . . . . . . . . . . 40

4.2.1 Exxon Valdez (Prince William Sound, Alaska) . . . . . . . . . 40

4.2 .2 S.S. Glacier Bay Oil Spill . . . . . . . . . . . . . . . . . 56

4.2 .3 Amazon Venture . . . . . . . . . . . . . . . . . . . 65

4.2.4 Mercer Statistical Data Base of Tanker Spill Costs . . . . . . . . . 70

4.3 Pipeline Spills . . . . . . . . . . . . . . . . . . . 71

4.3.1 Exxon Arthur Kill Oil Spill . . . . . . . . . . . . . . . 72

4.3.2 Texaco Anacortes Refinery Spill . . . . . . . . . . . . . . 83

4.4 Offshore Platform Spills . . . . . . . . . . . . . . . . 85

4.4.1 Union/Texaco Platform (Santa Barbara, California) . . . . . . 85

4.4.2 Ixtoc Platform (Gulf of Mexico) . . . . . . . . . . . . . 89

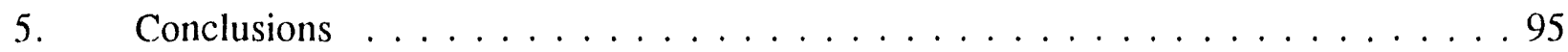

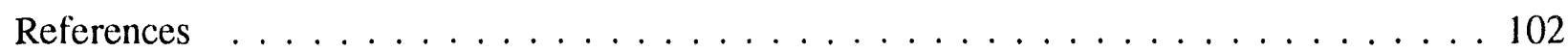

Appendix 1 - Oil Spills in U.S. Waters $1973-1990$ 


\section{List of Exhibits}

Page

Exhibit 1-1 Gross national product - implicit price deflator $\ldots \ldots \ldots \ldots$

Exhibit 2-1a Examples of travel cost model (TCM), spatial recreation market $\ldots \ldots$. . 8

Exhibit $2-1 \mathrm{~b}$ Examples of travel cost model (TCM), demand curve $\ldots \ldots \ldots$

Exhibit 2-2 Predicted means and 90 percent confidence intervals for open-ended oil spills versions . . . . . . . . . . . . . 13

Exhibit 3-1 Development of natural resource damage assessment regulations: $1980-1993 \ldots \ldots \ldots \ldots 17$

Exhibit $3-2 \quad$ DOI NRDA regulations under CERCLA $\ldots \ldots \ldots \ldots$

Exhibit 3-3 Time profile of a generic one-time oil spill $\ldots \ldots \ldots \ldots$

Exhibit 3-4 Oil Pollution Act of 1990 - natural resource

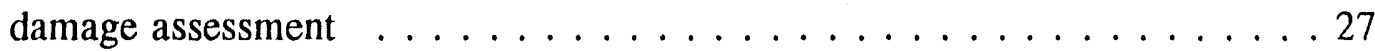

Exhibit 3-5 Oil effects rankings under State of Washington

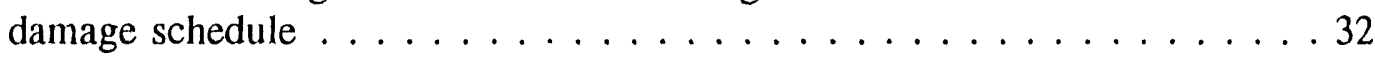

Exhibit $4-1$ Overview of oil spills analyzed $\ldots \ldots \ldots \ldots$

Exhibit 4-2 Map of the Exxon Valdez oil spill area . . . . . . . . . . . . 41

Exhibit 4-3 Summary of estimated costs and damages (top) and actual settlement due to the Exxon Valdez oil spill

Exhibit 4-4 Sport fishing effort for the Exxon Valdez oil spili area, $1984-1989 \ldots \ldots \ldots \ldots$. . . . . . . . . . . . . . . . 46

Exhibit 4-5 Estimates of damages to recreational fishing due to the

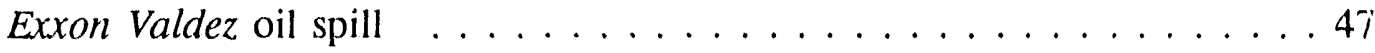

Exhibit 4-6 ARI's estimate of wildlife damages due to Exxon Valdez oil spill . . . . . 50

Exhibit 4-7 Program cost by version and question for the Exxon Valdez CV survey . . 52

Exhibit 4-8 Statistical distributions of WTP for Exxon Valdez oil spill . . . . . . . . . 53

Exhibit 4-9 WTP to prevent another oil spill in Prince William Sound . . . . . . 54 


\section{List of Exhibits}

(Cont.)

Page

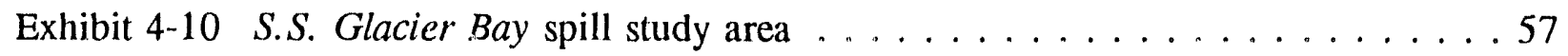

Exhibit 4-11 Cleanup costs and natural resource damages for the

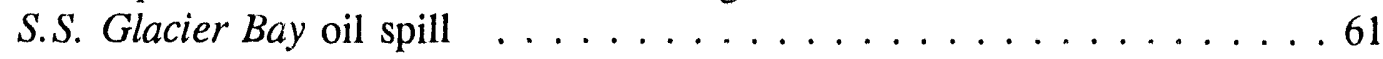

Exhibit 4-12 Map of the impact area for the Amazon Venture oil spill . . . . . . . 66

Exhibit 4-13 Natural resource damages for the Amazon Venture oil spill . . . . . . . 68

Exhibit 4-14 Actual settlements of natural resource damages for two

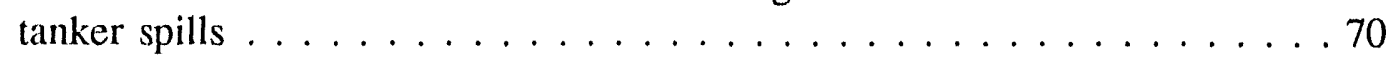

Exhibit 4-15 Location of Exxon's Arthur Kill oil spill $\ldots \ldots \ldots \ldots \ldots \ldots$

Exhibit 4-16 Components of Exxon's settlement for the 1993 Arthur Kill oil spill . . . 75

Exhibit 4-17 RTI's estimated range of potential damage from Exxon's Arthur Kill oil spill . . . . . . . . . . . . . . . . 77

Exhibit 4-18 Estimates of natural resource damages related to Exxon Arthur Kill oil spill $\ldots \ldots \ldots \ldots \ldots \ldots \ldots \ldots \ldots$

Exhibit 4-19 Major components of Texaco's settlement from the 1991 Anacortes,

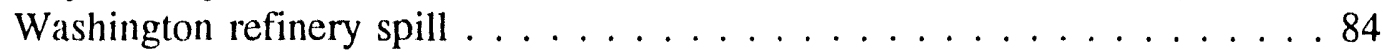

Exhibit 4-20 Area contaminated with oil from Union Oil Co. Platform A

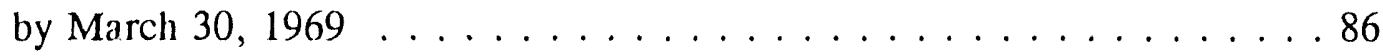

Exhibit 4-21 Location of the Ixtoc I blowout site in the western Gulf of Mexico . . . . 90

Exhibit $4-21$ Summary of damages from the Ixtoc I blowout $\ldots \ldots \ldots . \ldots \ldots 9$

Exhibit 5-1 Summary of per-bbl costs and damages from marine oil spills . . . . . . 98

Exhibit 5-2 Most likely ranges of spill unit values for three oil supply components . . 99

Exhibit $5-3$ Oil spilled in U.S. waters $1973-1990 \ldots \ldots \ldots \ldots$

Exhibit 5-4 ARI's calculated damages due to oil spilled in U.S. waters based on average spill unit cost $(\$ 283 /$ gal $) \ldots \ldots \ldots \ldots 10 \ldots \ldots$ 


\section{Executive Summary}

The impacts of oil spills -- ranging from the large, widely publicized Exxon Valdez tanker incident to smaller pipeline and refinery spills -- have been costly to both the oil industry and the public. For example, the estimated costs to Exxon of the Valdez tanker spill are on the order of $\$ 4$ billion, including $\$ 2.8$ billion (in 1993 dollars) for direct cleanup costs and $\$ 1.125$ billion (in 1992 dollars) for settlement of damages claims caused by the spill. Application of contingent valuation costs and civil lawsuits pending in the State of Alaska could raise these costs appreciably. Even the costs of the much smaller 1991 oil spill at Texaco's refinery near Anacortes, Washington led to costs of $\$ 8$ to 9 million. As a result, inexpensive warning, response and remediation technologies could lower oil spill costs, helping both the oil industry, the associated marine industries, and the environment.

One means for reducing the impact and costs of oil spills is to undertake research and development on key aspects of the sil spill prevention, warning, and response and remediation systems. To target these funds to their best use, it is important to have sound data on the nature and size of spills, their likely occurrence and their unit costs. This information could then allow scarce $R \& D$ dollars to be spent on areas and activities having the largest impact.

This report, prepared on behalf of the Office of Domestic and International Energy Policy, U.S. DOE, is intended to provide the "unit cost" portion of this crucial information. The report examines the three key components of the U.S. oil supply system, namely, tankers and barges; pipelines and refineries; and offshore production facilities. The specific purpose of the study was to establish the unit costs of oil spills. By manipulating this key information into a larger matrix that includes the size and frequency of occurrence of oil spills, it will be possible to estimate the likely future impacts, costs, and sources of oil spills.

Analysis of damage assessments conducted on tanker spills, including the Exxon Valdez, S.S. Glacier Bay, Amazon Venture, and several other tanker spills indicates that overall spill unit values vary widely, from approximately $\$ 5$ to $\$ 570$ per gallon (1993\$). All components of tanker spill costs can vary, depending primarily on location of the spill. Response and cleanup costs varied from less than $\$ 5$ to as much as $\$ 257$ per gallon. Direct use natural resource 
damages varied from less than $\$ 5$ to $\$ 363$ per gallon. Non-use damages measurer using contingent valuation can be equally volatile, ranging from an estimated $\$ 5$ to $\$ 284$ per gallon. This cost variability reflects the mobility of tankers: tanker spills in open marine environments result in relatively low cleanup costs and natural resource damages, whereas tanker spills in sensitive coastal areas can cause extensive damages and require costly cleanup. Based on the case studies selected, there is no apparent correlation between unit costs and spill size. Although larger spills may benefit from economies of scale in cleanup, they are equally likely to result in disproportionately high costs due to more easily measured natural resource damages and larger non-use damages due to heightened publicity.

Oil spills from pipelines and refineries tend to cause lower spill unit costs with less variability than tanker spills. Analysis of Exxon's Arthur Kill pipeline spill and Texaco's Anzcortes refinery spill revealed that total spill unit values ranged from $\$ 45$ to $\$ 125$ per gallon, of which the response and cleanup cost component showed little variation at $\$ 34$ to $\$ 39$ per gallon. Pipeline and refinery spills tend to occur in industrialized wetlands or coastal areas, where potential direct use and non-use damages are less than in non-industrialized areas. Prevention costs for monitoring equipment and training tend to be an important component of natural resource damage settlements for pipeline/refinery spills, reflecting their efficacy in preventing oil spills at these non-mobile facilities.

Spill unit values for offshore production facilities are very poorly defined, due largely to the excellent safety record of these facilities in the U.S. over the past two decades. Published damage assessment studies for the Santa Barbara and Ixtoc platform spills pre-dated CERCLA and OPA legislation and are relatively unsophisticated. Oil spills from offshore facilities may be capable of a wide range of natural resource damages, similar to tanker spills, depending primarily upon spill environment. Unit cost values for platform spills in an open marine setting (such as the Gulf of Mexico) tend to be low, reflecting the diminished sensitivity and higher dilution capability of this environment. However, an oil spill in a sensitive coastal area, comparable to the 1969 Santa Barbara oil spill, would probably lead to significant cleanup and direct use damages, and extremely high spill unit costs for non-use natural resource damages. 
Coast Guard data indicate that tanker spills have accounted for the overwhelming proportion of oil spills in U.S. waters since 1973, measured by both number of incidents and volumes spilled. Oil spilled in major ( $>100,000 \mathrm{gal}$ ) tanker incidents has averaged about 5 million gallons per year during this time period. Applying an average spill unit cost of $\$ 283$ per gallon, determined in this study, tanker spills in U.S. waters on average are estimated to have caused in excess of $\$ 1$ billion (1993\$) in cleanup costs and damages annually, for an estimated total cost to the economy of over $\$ 25$ billion during this period. Although oil spills cleanup operations can generate significant economic activity, cleanup costs and damages may be considered net losses to the economy and particularly to the oil supply system. This is because cleanup expenditures directly reduce the funds available for productive investment in petroleum exploration, development, and processing, such as in the case of the Exxon Valdez or other major oil company spills.

The results of this study provides a framework for DOE oil spill R\&D priorities. However, in addition to spill unit values of economic damages from oil spills, it is also necessary to consider the risks of an oil spill actually occurring. Coast Guard records indicate that tanker spills occur most frequently in U.S. waters, with pipeline/refinery spills less frequent, and offshore facility spills quite rare (international data on spill frequency are not available). Oil spill research and development focused on tanker spills could be the most cost-effective in reducing spill costs and impacts. Pipeline/refinery research would be the next most important oil supply component to be targeted for oil spill $R \& D$, because spill unit values for these f:cilities are moderately high and because these accidents are next most frequent following tanker spills. Offshore facilities have the potential to generate large non-use damages, but are infrequent; thus offshore facilities are not strongly recommended for oil spill R\&D. 
Summary of per-bbl costs and damages from marine oil spills. (All values in $1993 \$ /$ gal)

\begin{tabular}{|c|c|c|c|c|c|c|c|c|}
\hline & $\begin{array}{l}\text { Cleanup } \\
\text { Costs }\end{array}$ & $\begin{array}{l}\text { Capital } \\
\text { Losses* }\end{array}$ & $\begin{array}{l}\text { Prevention } \\
\text { Costs }\end{array}$ & $\begin{array}{l}\text { NRDA } \\
\text { Costs }\end{array}$ & $\begin{array}{l}\text { Direct Use } \\
\text { Damages }\end{array}$ & $\begin{array}{l}\text { Non-Use } \\
\text { Damages }\end{array}$ & Total* & $\begin{array}{c}\text { Actual } \\
\text { Settlement } \\
\text { and Costs } \\
\end{array}$ \\
\hline \multicolumn{9}{|l|}{ Tanker } \\
\hline Glacier Bay & 18.58 & 0.43 & -- & -- & 363.51 & $5.46^{*}$ & 390 & -- \\
\hline Exxon Valdez & 257.00 & 0.40 & -- & $9.91-19.81$ & 13.67 & 283.99 & $564-574$ & 370.00 \\
\hline Amazon Venture & $2.75^{*}$ & 0.35 & -- & 0.26 & 0.86 & 1.71 & 5.93 & 3.00 \\
\hline $\begin{array}{l}\text { Mercer Data } \\
\text { Base }\end{array}$ & -- & - & - & - & -- & -- & -- & $4.15-37.90$ \\
\hline \multicolumn{9}{|l|}{ Pipeline/Refinery } \\
\hline $\begin{array}{l}\text { Exxon Arthur } \\
\text { Kill }\end{array}$ & 33.97 & 0.38 & 47.17 & $1-5^{*}$ & 0.09 & $10.43-38.72$ & $93-125$ & 109.35 \\
\hline $\begin{array}{l}\text { Texaco } \\
\text { Anacortes }\end{array}$ & 38.69 & 0.08 & 3.81 & -. & 2.38 & -- & 45 & 44.88 \\
\hline \multicolumn{9}{|l|}{ Offshore Platform } \\
\hline Ixtoc & 3.25 & 1.43 & -- & -- & 0.21 & $6.5-12.9^{*}$ & $11-18^{*}$ & -- \\
\hline Santa Barbara & 43.16 & 0.30 & -- & -- & -- & $50->100 *$ & $93->143^{*}$ & - \\
\hline
\end{tabular}

\section{*ARI Estimate}




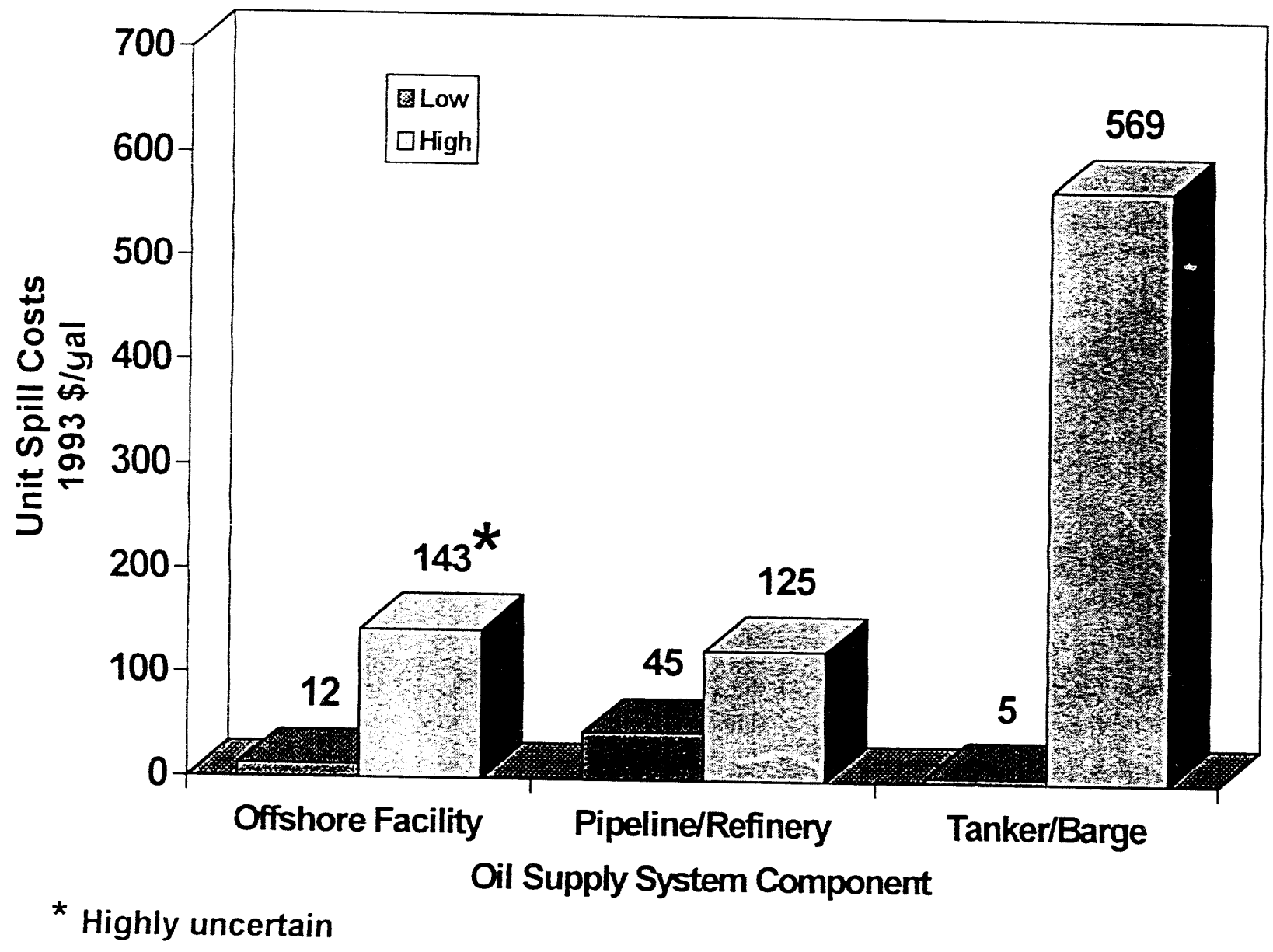

Most likely ranges of spill unit values for three oil supply components 


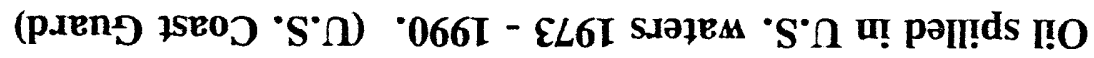

มอว人

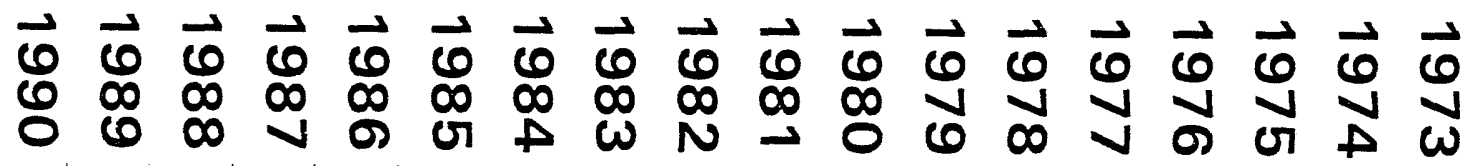

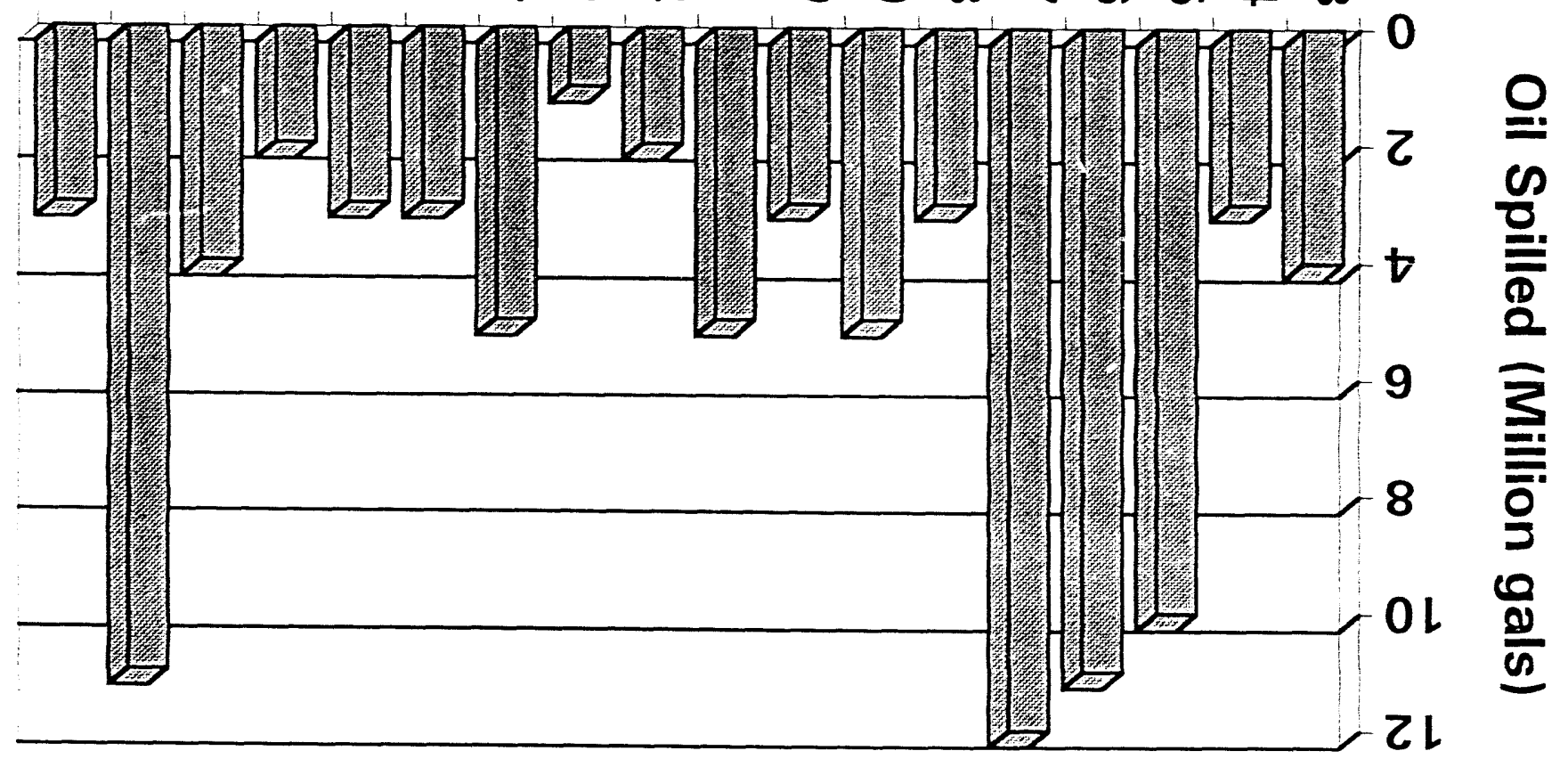




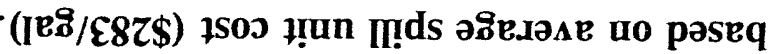

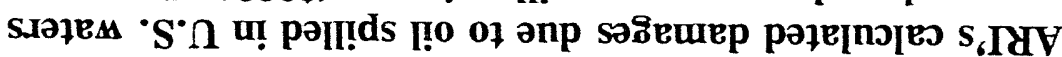

נeә入

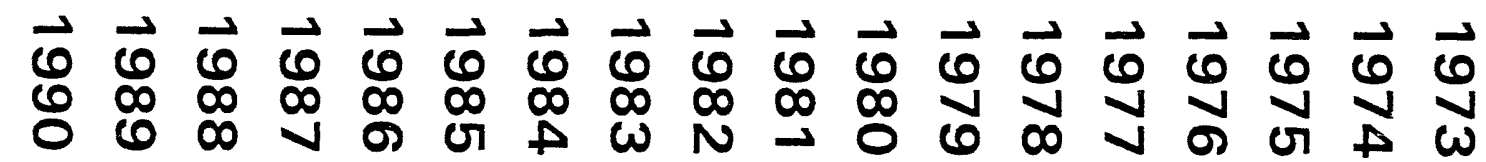

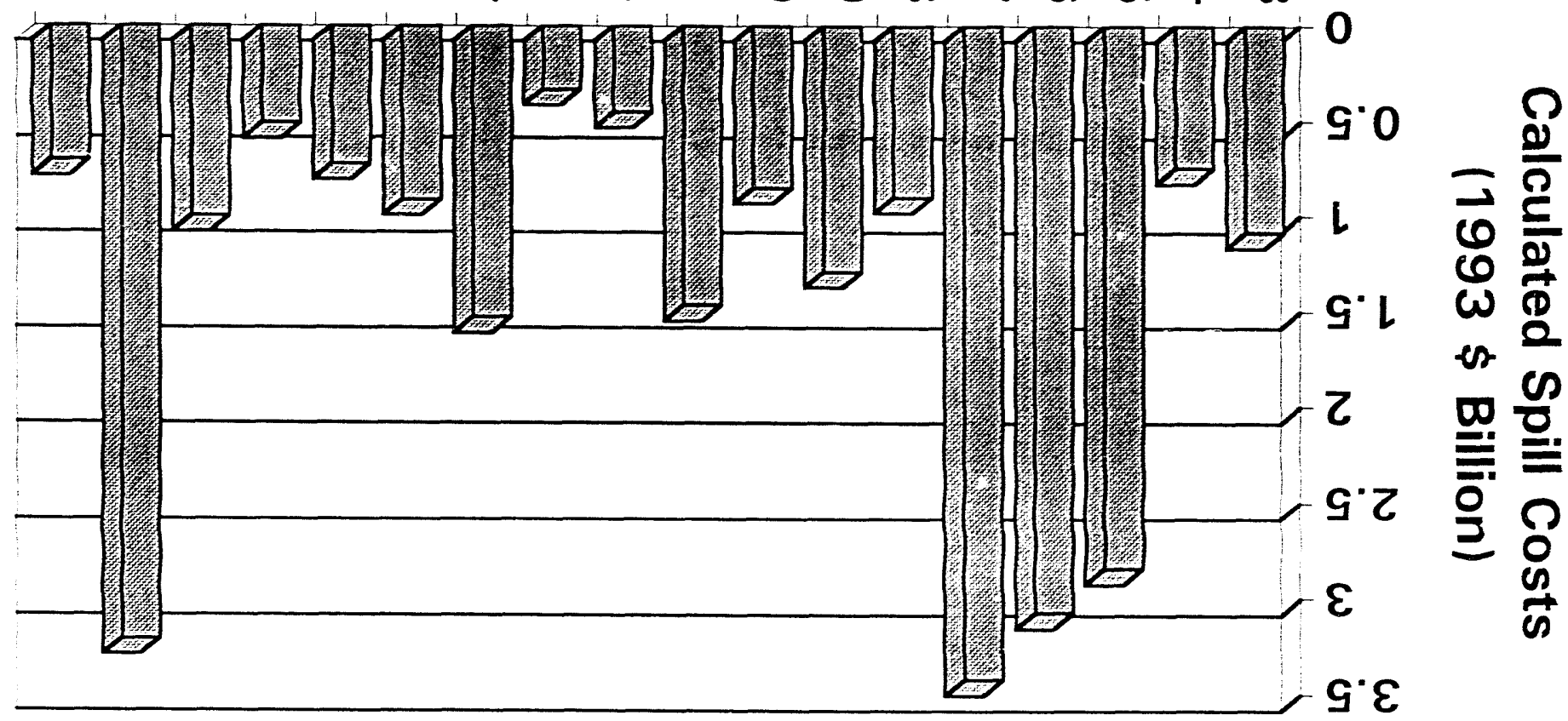




\section{Introduction}

\subsection{Overview and Purpose of Study}

The enactment of the Oil Pollution Act of 1990 (OPA 90) followed a series of damaging oil spills in the U.S., including the 11-million gallon Exxon Valdez spill in 1989 and a series of three subsequent smaller spills which occurred within a 24-hour period in coastal U.S. waters. These highly publicized events focused the issue of compensation for cleanup and economic damages resulting from oil spills and helped to shape the provisions of the Act. OPA 90 set forth with unprecedented clarity the methods and penalty guidelines to be used for assessing natural resource damages that resulted from oil spills. While some of these methods remain controversial, and damage regulations still remain to be finalized three years after enactment, a consensus on damage assessment theory and application is slowly taking shape within the economic research community. Sufficient data is now also becoming available on the economic impacts of oil spills, helping to target the components of the oil supply system most responsible for costly natural resource damages.

In addition to specifying natural resource damage procedures, OPA 90 authorized research and development expenditures in oil spill mitigation and remediation. The direction, funding, and organizational control of this research remains to be formulated. The U.S. Department of Energy, which is charged with oversight of the energy supply of the United States, is one of many agencies jointly authorized to perform oil spill R\&D under the Act. However, more specific information on the nature and costs of oil spills as well as the oil spill prevention, response and remediation system is needed for developing a cost-effective oil spill R\&D program. Assembling a portion of this essential information is the purpose of this study.

This report was prepared on behalf of the Office of Domestic and International Energy' Policy, U.S. Department of Energy (DOE), in response to a Task Assignment entitled "Oil Spill Costs: Estimates and Methods of Measure." The report provides a survey and analysis of the economic impacts of various types of oil spills, based on a critical review of published assessments performed on representative oil spills in different regions of the United States. Using this information, ARI has developed a likely range of costs and damages caused by oil 
spills to major industry, government, and other groups and has used these cost data to quantify and characterize the economic costs of oil spills. This information is intended to assist costbenefit analysis to be performed by DOE for determining the most effective investment program in oil spill research and development.

\subsection{Sources of Data}

Information on the economic costs of oil spills was obtained from published studies. In some cases, study authors were contacted for clarification and additional information. It should be noted that, with the exception of the Exxon Arthur Kill study discussed in Section 4, all natural resource darnage assessments discussed in this report were funded by trustees charged with protecting these resources on behalf of the public and authorized to levy damages from responsible parties for cleanup and restoration costs. The petroleum industry's point of view, or even the opinion of independent observers, is rarely set forth in these published studies. Nearly every natural resource damage case that has been resolved to date has led to an out-ofcourt settlement considerably lower than originally assessed damages. Consequently, it is possible that some of the published reports may reflect larger assessments of damages than would be determined in an adjudicated process reflecting the views of all parties.

Nevertheless, the studies reviewed in this report appeared to have taken a reasonable approach to valuing natural resource damages. For example, contingent valuation studies, which remain controversial but have been endorsed by NOAA as primary natural resource trustee under OPA 90, have invariably selected the willingness-to-pay mechanism and other conservative safeguards in estimating passive use values.

\subsection{Methodology}

As an introduction to the case studies analyzed in Section 4 of this report, some basic economic and regulatory background is first provided in this report. Section 2 provides an overview of the economic concepts used in natural resource damage assessments. Section 3

discusses in detail the development of natural resource damage assessment regulations and 
methodologies. After the discussion of the case studies in Section 4, which contain the bulk of the assessment data, the major conclusions of this study are presented in Section 5.

Three primary oil supply systems were identified as potential sources of oil spills and possible candidates for future DOE research on oil spill prevention, response and remediation. Tankers and barges have accounted for the large majority of oil spills, and thus were given primary emphasis in Section 4 of this report. Four tanker case studies were selected for analysis of the economic impacts of oil spills: the S.S. Glacier Bay, the Exxon Valdez, the Amazon Venture, and a series of four tanker spills which appear in a proprietary oil spill data base. Oil spills resulting from barges, which are towed tankage vessels that operate in coastal waters with oil spill risks similar to those facing tankers, were categorized along with tanker spills, but no case studies were selected for analysis.

The second oil supply system analyzed was the combined pipeline/refinery category. Pipelines and refineries were grouped because they are both stationary sources with similar risks and characteristics of oil spills. Pipeline and refinery spills frequently occur in environmentally sensitive wetlands or other protected coastal locations and thus can benefit appreciably from early warning and spill control technology. (However, some pipeline and refinery spill locations are industrialized settings with relatively limited recreational value.) Extensive information on natural resource damages is available for two pipeline/refinery case studies: the Exxon Arthur Kill pipeline spill and the Texaco Anacortes refinery spill.

The third oil supply system is the offshore petroleum facility, including oil production platforms and drilling rigs. Offshore petroleum facilities have not experienced any major ( $>1,000$ bbls or 42,000 gals) oil spills during the past decade and a half in the United States (Opaluch and Grigalunas, 1989), demonstrating an excellent safety record in both gross and perbbl terms. However, owing to this superior safety record, only comparatively unsophisticated or fragmentary information is available on the economic impacts of oil spills from offshore production facilities. The Santa Barbara and Ixtoc oil spills are the only platform spills for which data are available, and consequently were relied on extensively for this analysis. Nevertheless, offshore petroleum facilities remain capable of generating very large natural resource damages under the OPA 90 regulatory framework if a major oil spill should occur. 
Costs cited in this report are presented in both nominal dollars and adjusted 1933 dollars. To permit direct comparison between oil spills and court settlements that occurred at different times, nominal costs were adjusted to January 1, 1993 levels using the GNP Implicit Price Deflator prepared by the Bureau of Economic Analysis, Department of Commerce (Exhibit 1-1).

To provide a mechanism for comparing costs from different sized oil spills, economic impacts were normalized to a spill unit value (per-gallon) basis. Because limited information was available, the volume of oil spilled was not adjusted for evaporation, fire consumption (with the exception of Ixtoc), rapidity and efficacy of cleanup operations, or other factors that may have affected the actual volume of oil causing the impacts. 


\section{Natural Resource Damage Assessment Methodologies}

\subsection{Introduction}

A number of alternative methods are available for evaluating natural resource damages. Market-based methods -- such as market price and appraisal -- are generally the most reliable, assuming that efficient markets for natural resource services exist. However, markets for many natural resource services are often flawed or non-existent. Such market failures lead to externalities, where the action of one economic agent affects the well-being or production possibilities of another in a way that is not reflected in the marketplace.

Where market failures occur, related markets may be used to reveal natural resource values. Related market methodologies include the factor income, travel cost, and hedonic pricing methods. Finally, hypothetical markets, such as contingent valuation surveys, need to be developed to reveal non-use values for natural resource services, for which markets are completely non-existent.

\subsection{Market-Based Methods}

The market price method simply relies on the existing market for the resource to measure diminution in market price due to injury. An example of the market price method would be to apply the market price of salmon in assessing fishery damages caused by an oil spill. The appraisal method can be used where a market exists for existing or similar resources, such as coastal real estate values affected by a nearby oil spill. Natural resource damages are measured as the difference in price between injured and non-injured appraised values.

\subsection{Revealed Preference Methods}

Revealed preference measures have been developed to estimate natural resource values when market prices are not available. These methods rely on observed behavior or market data 
(that reveal preferences) to infer values for nonmarket resources. Three general types of revealed preference approaches are currently in use: travel cost, hedonic pricing, and factor income methods. Each method uses a different type of linkage between a marketed commodity and a non-marketed resource. Although current DOI and proposed NOAA regulations call specifically for the use of these three methods, only the travel cost method has been extensively used to date for determining natural resource damages from oil spills.

The travel cost method is used for valuing the recreational use of sites where travel is essential to access to the resource. The travel cost approach relies on the relationship between marketed travel services and a non-marketed resource such as recreational fishing. Often, access to a recreational site is free or requires only a nominal fee. However, there may be significant costs associated with visiting the site, frequently many times greater than the cost of access, which may be interpreted as an implicit price of the visit. A demand relationship can be constructed by examining the number of visitors traveling from a variety of distances to the site, which tends to diminish as distance from the site increases (Exhibit 2-1).

The travel cost approach to measuring natural resource services is widely accepted in the economics profession and has been incorporated into the DOI and NOAA natural resource damage assessment regulations. Travel cost methodology was used by many of the damage assessments discussed in Section 4 of this report (e.g., Carson and Hanemann, 1992), primarily to n. easure the value of lost hunting and fishing and nonconsumptive wildlife viewing due to oil spills.

The factor income method may be used if an injured resource is an input to a production process that generates a product with a well-defined market price. The resources best suited to the factor income approach include surface and ground water resources (as inputs to irrigated agriculture), forests (as inputs to manufactured goods), and commercial fisheries. For example, an oil spill may reduce non-commercial fish stocks, increasing production costs for a commercial fish which feeds upon the damaged fish and leading to a decrease in producer surplus or economic rent. 


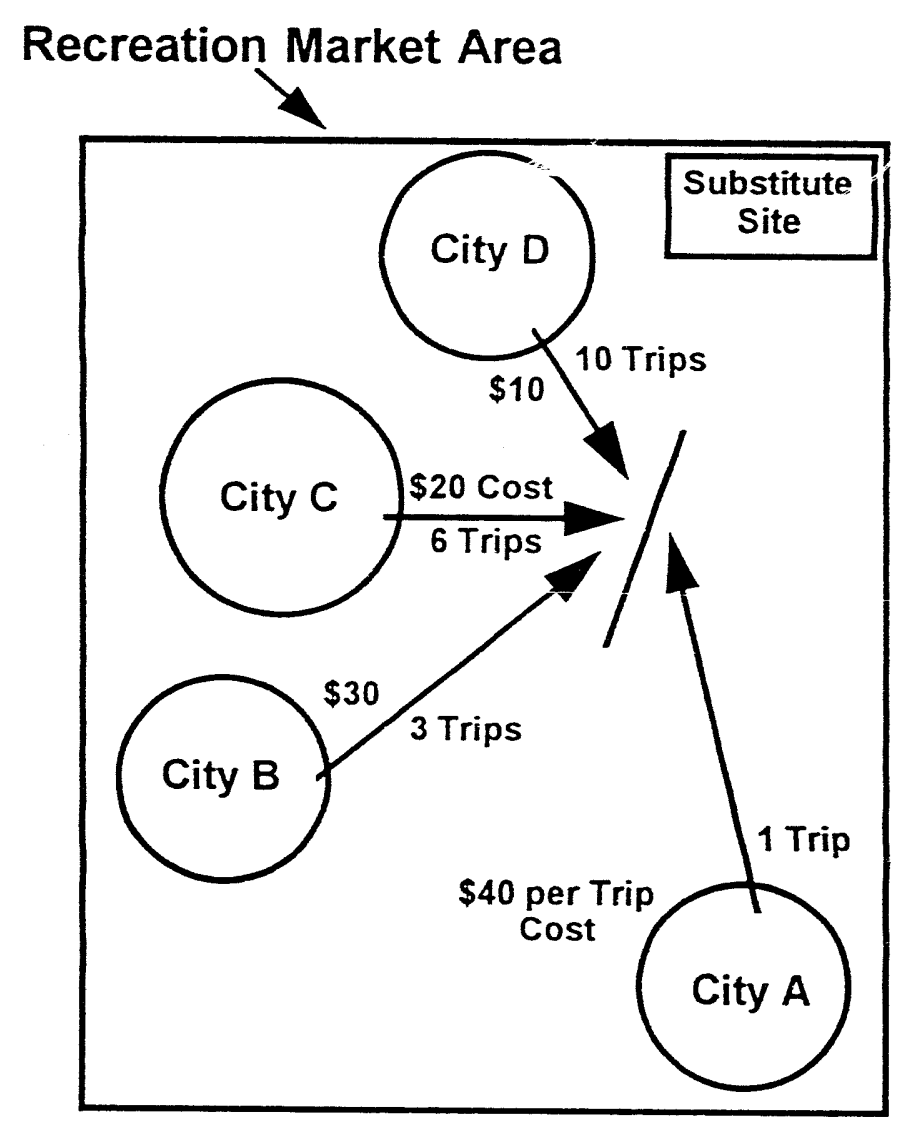

Exhibit 2-1a: Examples of travel cost model (TCM), Spatial Recreation Market.

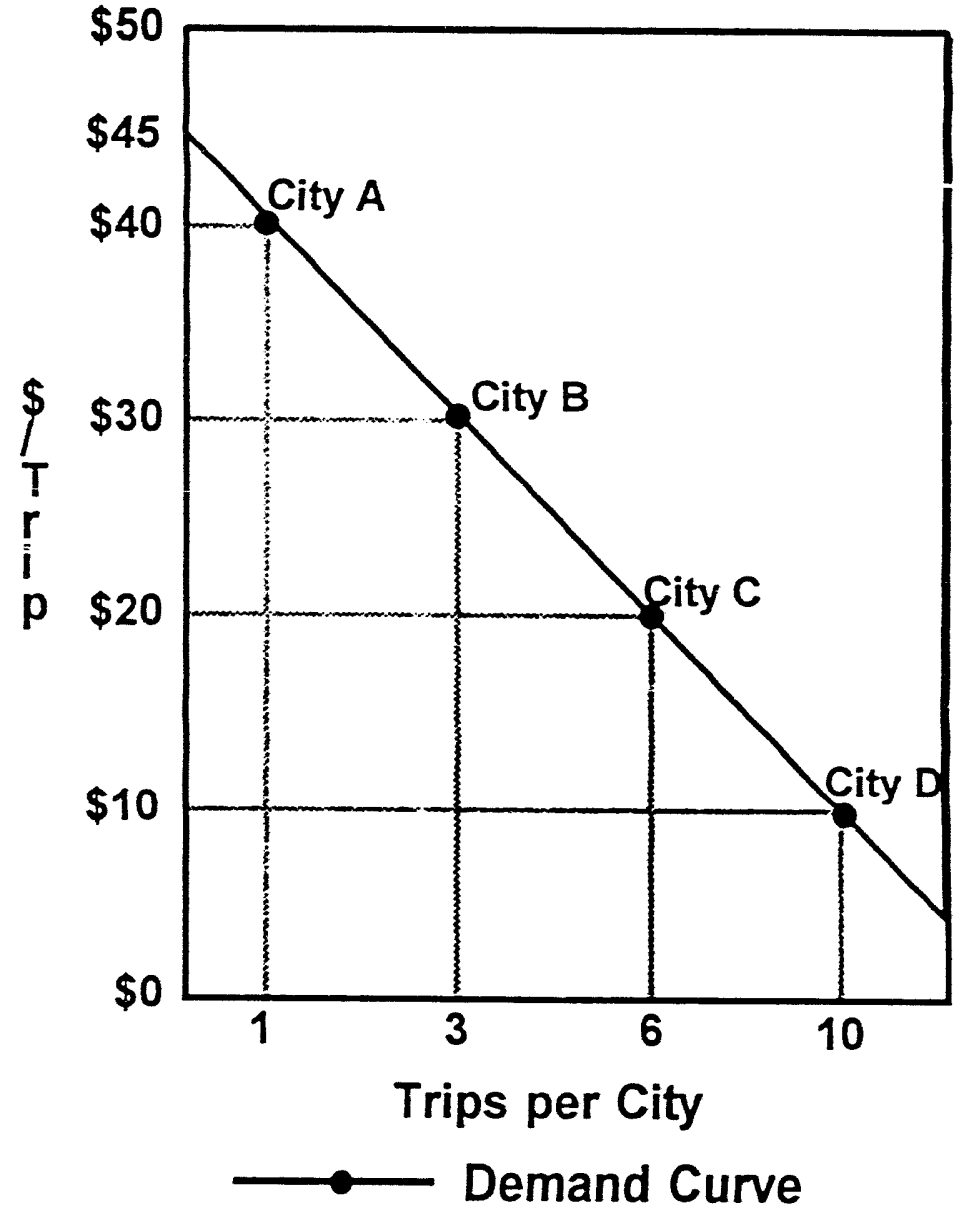

Exhibit 2-1b: Examples of travel cost model (TCM), Demand Curve. 
Factor income methodology, although identified as an allowable approach in the DOI and proposed NOAA damage assessment regulations, is not as well established as the hedonic pricing and travel cost methods. Furthermore, to perform factor income analysis, it is necessary to develop an engineering-economic model relating production costs to output levels, and also a model of how changes in resource quality affect production costs. This level of information is seldom available for oil spill related natural resource damages. None of the studies discussed in Section 4 relied on factor income methodology.

Hedonic pricing uses the linkage between the market price of real estate and the quality of the surrounding environment to infer values for natural resource damages. This method disaggregates the individual components that determine the market price for real estate to determine the effect of natural resource services on the value of the commodity. Hedonic pricing is based on the assumption that the benefits of an environmental service, such as clean shoreliıes, is capitalized into property values.

The hedonic price method is useful for environmental changes, such as air pollution, that are long lasting enough to affect property values. However, individual oil spills generally have not been found to cause long-term damage to property values, although toxic spills over time have affected prices in parts of the U.S.; one study of the neighborhood adjacent to New Bedford harbor determined that PCB contamination led to a decline of up to $8 \%$ in property values, for a total natural resource damage of $\$ 20.6$ million paid under CERCLA regulations (Mendelsohn, 1986). Another weakness is that the method does not work well where land is publically held and market sales transactions are limited. Consequently, hedonic pricing, although certified as an accepted valuation method under the DOI and proposed NOAA regulations, has not been cited to date in the literature as an important method for measuring possible injuries to real estate from oil spills.

\subsection{Contingent Valuation}

The most controversial approach to valuation of natural resource damages is contingent valuation $(\mathrm{CV})$. CV methodology develops values for non-traded goods and services simply by 
asking people how much they believe the goods and services are worth. In this way, CV attempts to construct a theoretical market to assign values to certain non-use public goods which have recently been recognized as valid economic entities. Examples of such non-use public goods include the future option to visit a recreation site, or the desire to have the resource available for use by others of either the present or future generations. CV methodology is widely recognized in the economic community as the only existing approach for valuing non-use natural resource services.

\section{Critical Components of a CV Survey}

Despite the sound theoretical basis of contingent valuation, actual implementation of this method remains highly controversial. Some of the critical components of CV survey design which have been debated include:

1) Definition of Affected Population. One of the most important and controversial aspects of $\mathrm{CV}$ design is definition of the size and location of the population which, while not currently users of the injured resource, may still hold some nonuse value of the resource. Some studies have argued that the entire population under the government agency that is assessing the resource as trustee should be counted. Others argue that the study size should be restricted to a much smaller base of population directly affected by the oil spill. Population size in CV studies has varied from several thousand for a local town affected by a small spill, up to the entire U.S. population for the Exxon Valdez spill. Since average per-person or per-husehold non-use values are multiplied directly by the selected population group, CV valuations are highly sensitive to this factor.

2) Definition of the Injured Resource. For the results of the CV survey to be valid, the injury to the natural resource must be presented in a detailed yet understandable manner. People need enough data and context to develop a realistic concept of what they are valuing, without being led to adopt a higher value than they actually hold for the resource.

3) Definition of Payment Vehicle. A specific mechanism is necessary for respondents to express their non-use value. For best results, this payment vehicle should be both realistic and neutral. For CV studies of non-use values related to oil spills, the payment vehicle usually involves the respondent paying higher 
income or gasoline taxes to pay for programs to avoid or clean up future spills. Taxes are a realistic payment vehicle, but values may be biased downward if respondents convert the CV question into an expression of dissatisfaction with taxes, rather than a value for the resource.

4) Willingness to Pay Versus Willingness to Accept. Numerous CV studies have determined that Willingness to Accept values for natural resource services are generally 3 to 5 times larger than Willingness to Pay values. For example, a study of the value of goose hunting permits in Wisconsin showed that hunters were willing to pay an average of $\$ 21$ for a permit, but demanded an average $\$ 101$ to give up a permit they already owned (Bishop and Heberlein, 1992). No data are available comparitig WTP and WTA for natural resource damages due to oil spills. Administrators of oil spill CV surveys have generally taken the relatively conservative approach of eliciting only WTP measures.

5) Detection of Bias. CV answers are highly dependent upon the way the central question is phrased and on suggested answers. Bias can result because of:

Hypothetical bias. The respondent likely has never considered valuing the resource, and has no experience in exploring the market for substitutes or other information. Consequently, it is common for the respondent to use suggested answers as a starting point about how much their values ought to be.

Intentional misleading. Strategic behavior can occur if the respondent realizes that the CV question is purely hypothetical and that stating a very high value will promote supply of a desired public good.

\section{Criticism of CV Methodology}

Contingent valuation remains a highly controversial method for determining non-use natural resource values and damages. A number of specific objections have been raised to $\mathrm{CV}$ methodology and empirical studies have frequently identified inconsistent survey results. It has been argued in the economic literature that the results of $\mathrm{CV}$ studies are variable, sensitive to details in the survey questionnaire, and vulnerable to upward bias. Some economists go so far 
as to suggest that there can be no useful information content to CV results. Some of the most serious criticisms of CV methodology include:

Public has exaggerated perceptions of oil spills. Biases caused by respondent misperceptions are among the most important sources of error in CV surveys. It is well known that due to media attention, the public has highly exaggerated perceptions of the environmental hazards of oil spills. "Oil spills are now thought (by the public) to be the fifth most serious of the 2.9 environmental problems Roper asked about, despite expert agreement that they pose relatively low risks to the environment and human health" (Grigalunas and Opaluch, 1993). Moreover, the highly controversial nature of oil spills risks the respondents sending emotional symbolic responses based on moral or ethical judgments of blame, rather than specifically valuing the injuries described in the survey questions.

CV answers can be inconsistent with rational choice. For example, one constructed CV survey found respondents willing to pay $\$ 129$ in higher gasoline taxes to control small spills through the establishment of lonal response centers, but only $\$ 81$ to control all spills (including large Exxon Valdez-sized spills) through the establishment of local and regional response centers (Exhibit 2-2; Dunford et al., 1993). These results indicate that people may have fixed-sized non-use values, regardless of the actual physical damage of the spill (same for Arthur Kill as 1or Exxon Valdez). Alternatively, people may have size-sensitive preferences but CV is not suitable for damage assessment.

Reported W'TP often exceeds actual W'TP. Direct tests of the "reality" of CV in estimating direct use values have been performed using ordinary market goods. The CV approach has tended to systematically overestimate the quantity demanded at each price, by as much as 50 percent in one study of demand for strawberries (Diamond et al., 1992). It is likely that CV methods will produce even higher errors when used to estimate indirect passive use values such as existence or bequeath value, for which no market exists and respondents are correspondingly less informed.

Respondents do not understand or fail to take the questions seriously. Respondents may not take the questions seriously because the results of the survey are not binding. In 


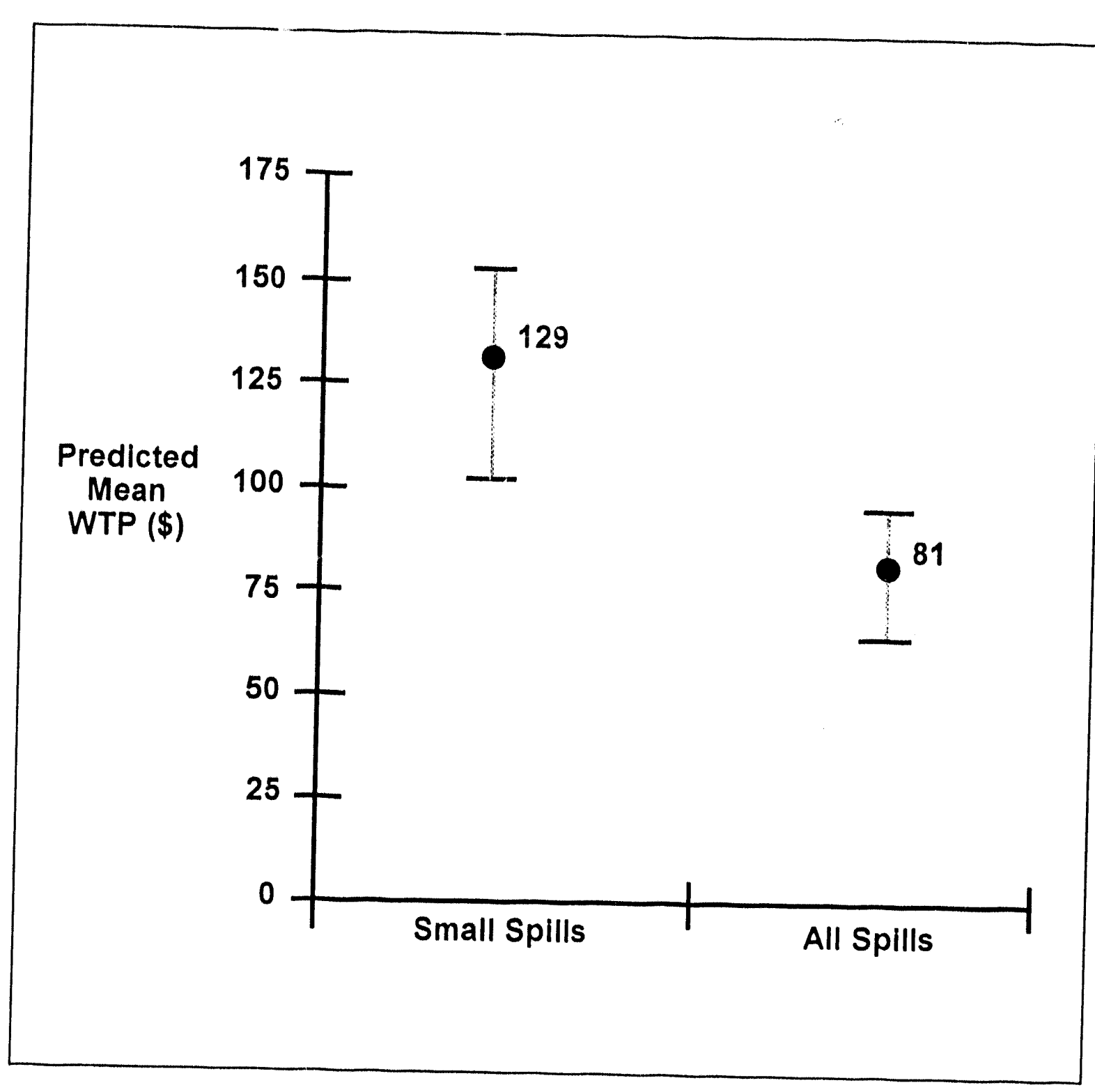

Exhibit 2-2:

Predicted means and 90 percent confidence intervals for open-ended oil spills version

addition, some responses indicate that respondents' value estimates are motivated by punitive intent, rather than focusing on the specific impacts of spills. Along a similar line of reasoning, respondents mi. it feel pressure to provide a "good" answer, particularly when responding to an interviewer, which differs from their actual belief. Finally, respondents may be motivated by the "warm glow" of doing something praiseworthy, such as contributing to environmental protection. 
Respondents cannot calculate NPV for multi-year damages. Passive use damages may be spread out over many years. Therefore, respondents would need to make complex discounting calculations to compute a single value.

\section{NOAA Contingent Valuation Panel}

Recognizing the controversy surrounding the use of contingent valuation to assess non-use natural resource damages, NOAA convened a panel of prominent economists during 1992 to evaluate the use of this methodology. NOAA intended that reliance upon a presumably independent academic panel would permit an unbiased analysis of CV methodology. The 6member panel was co-chaired by Nobel economists: Kenneth Arrow, who has written extensively on CV methodology during the past decade; and Robert Solow, an economist with no particular specialization in $\mathrm{CV}$.

Kenneth Arrow (co-chair) Professor of Economics, Stanford University (Nobel Laureate)

Robert Solow (co-chair) Professor of Economics, MIT (Nobel Laureate)

Paul Portney

VP and Senior Fellow, Resources for the Future

Edward Learner

Professor of Econometrics, UCLA

Roy Randner

Economist, Bell Laboratories

Howard Schuman

Sociologist, Univ, of Michigan

The NOAA CV panel admitted that the previously mentioned criticisms of $\mathrm{CV}$ methodology have validity. However, the panel concluded that CV is the only currently available method for measuring passive use damages, and that error can be reduced through careful survey design. The panel recommended the following steps be taken to improve CV survey results:

1) The Willingness to Pay design in practice is more conservative than Willingness to Accept, despite their theoretical equivalence, and should be employed exclusively.

2) The valuation question should be posed as a vote on a referendum to enhance realism. 
3) Adequate information should be provided to respondents about the environmental damage that occurred. Respondents should also be reminded of their budget limits constraining their WTP, and about the existence of comparable natural resources as substitutes, both of which tend toward lower valuations.

4) An adequate time lapse should occur between the oil spill and the survey, so that the scenario of complete restoration appears plausible.

5) The survey should include a variety of other questions that can help to interpret the validity of the primary response questions. Checks on understanding and acceptance of the primary survey question should be provided. 


\section{Development of Natural Resource Damage Assessment Regulations}

\subsection{Overview}

During the past 13 years, several laws have been enacted which provide for the recovery of natural resource damages from oil spills. Under these laws, various federal agencies have been charged with developing guidelines (regulations) governing the assessment and collection of natural resource damages, but promulgation of the enacting regulations has been a slow and controversial process. To help summarize this complex history, discussed in more detail below, a timetable of the major post-1980 NRDA initiatives and regulatory milestones is presented in Exhibit 3-1.

The legal basis for recovery of natural resource damages was first explicitly established with the passage of the Comprehensive Environmental Response, Compensation, and Liability Act (CERCLA, or Superfund Act) in December 1980. CERCLA specified that these regulations should include both "direct and indirect injury," and required that the "replacement value" and the ability of the resource "to recover" should be included in the damage assessment. In response to this act, and following a several year delay, the U.S. Department of Interior (DOI) issued their natural resource assessment regulations in 1986-7.

However, the DOI regulations were challenged soon after publication by several states, environmental organizations, and industry groups. In a landmark ruling in July 1989, the D.C. Circuit Court of Appeals struck down the DOI regulations, ordering that non-use damages be given equal value to direct use damages (State of Ohio v. Department of Interior, 1989). In response to this ruling, DOI proposed revisions to their assessment regulations in 1992, with final regulations expected to be published in 1993.

As DOI continues to refine regulations pursuant to CERCLA, the National Oceanic and Atmospheric Administration (NOAA) is developing natural resource damage regulations pursuant to the Oil Pollution Act of 1990 (OPA). These regulations will govern assessments for discharges of oil occurring after August 18, 1990. NOAA has distributed these regulations to affected federal agencies and is expected to provide them for public review in the Fall of 1993. 


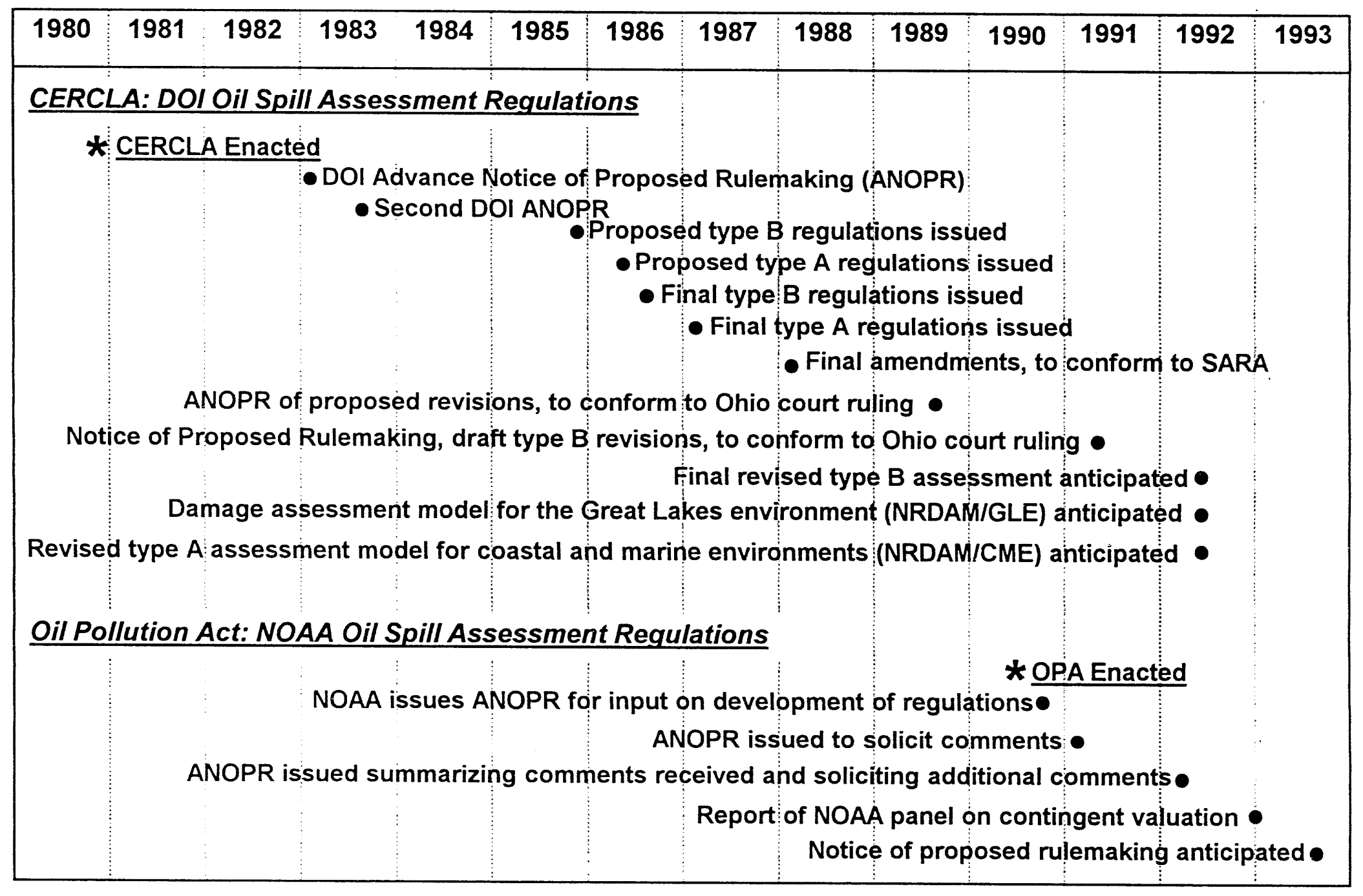

Exhibit 3-1:

Development of natural resource damage assessment regulations: 1980 - 1993 


\subsection{CERCLA}

The CERCLA regulations were the first to specifically address natural resource damage assessment. Under CERCLA, regulations were required to be developed to identify "the best available procedures" for determining natural resource damages, whether from oil spills or other pollutants. The Department of Interior (DOI), by Executive Order, was given responsibility for developing the CERCLA regulations, but failed to do so within the specified time period of December, 1982. Following a larger suit by several states, DOI issued "Type B" regulations, which provide for a relatively sophisticated assessment methodology, in September 1986. DOI's

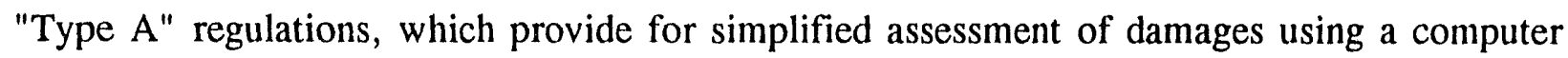
model, became effective in April 1987. Both procedures are being revised based on a federal court ruling which successfully challenged portions of the regulations. These two approaches are discussed below in detail.

\subsection{DOI Natural Resource Damage Regulations}

DOI developed two methodological approaches for conducting natural resource damage assessments. A Type A Model was developed for relatively rapid and low-cost assessment of small- to medium-sized spills in coastal and marine waters. The Type B Method specified a much more detailed and rigorous assessment for larger, more complex spills.

DOI's regulations provided for a hierarchy of methods for estimating lost use and non-use natural resource values. The following methods were specified for determining use values, in order of decreasing importance: 


\begin{tabular}{||l|l||}
\hline \multicolumn{1}{|c||}{ Market Characteristics } & \multicolumn{1}{|c|}{ Methodology } \\
\hline \hline For Reasonably Competitive Market & $\begin{array}{l}\text { Diminution in Market Price } \\
\text { Appraisal Methodology Based on "Uniform } \\
\text { Appraisal Standards for Federal Land } \\
\text { Acquisition." }\end{array}$ \\
\hline For Inefficient/Nonexistent Market & $\begin{array}{l}\text { Factor Income } \\
\text { Travel Cost } \\
\text { Hedonic Pricing } \\
\text { Unit Values }\end{array}$ \\
\hline To Be Used If Use Values Cannot \\
Be Determined
\end{tabular}

Type A Assessment. The Type A model is considered a pragmatic and cost-effective assessment technique for relatively minor oil spills. The purpose for Type A cost assessments is to avoid the high costs of full-scale assessments, which can be unreasonably high in the case of small- to medium-sized oil spills. For example, natural resource damages resulting from the 5,700-bbl Arco Anchorage oil spill in 1985 were determined to be $\$ 32,930$, yet assessment costs incurred were over seven times larger, totaling about $\$ 245,000$ (Grigalunas and Opaluch, 1988).

The Type A regulations for simplified assessments under CERCLA apply only to coastal and marine environments (Exhibit 3-2). The assessment phase requires the use of a "state-ofthe-art" computer model, which currently is the Natural Resource Damage Assessment Model for Coastal and Marine Environments (NRDAM/CME). The overall organization of the NRDAM/CME model, which was developed and maintained by the Fish and Wildlife Service, corresponds closely to the sequence followed in the more rigorous Type B assessment, discussed below (Exhibit 3-2). Individual physical fate, biological, and economic sub-models in the program are formulated to replicate injury determination, injury quantification, and damage determination, respectively.

The NRDAM/CME model partitions the marine environment of the U.S. into ten distinct province/ecosystem types for modeling purposes. Biological resources are assumed to vary by season, bottom type, marine versus estuarine environment, and tidal versus subtidal environments, for a total of 364 potential ecosystem/season categories. Economic damages are measured for injuries to commercial and recreational fisheries; waterfowl, shorebirds, and 


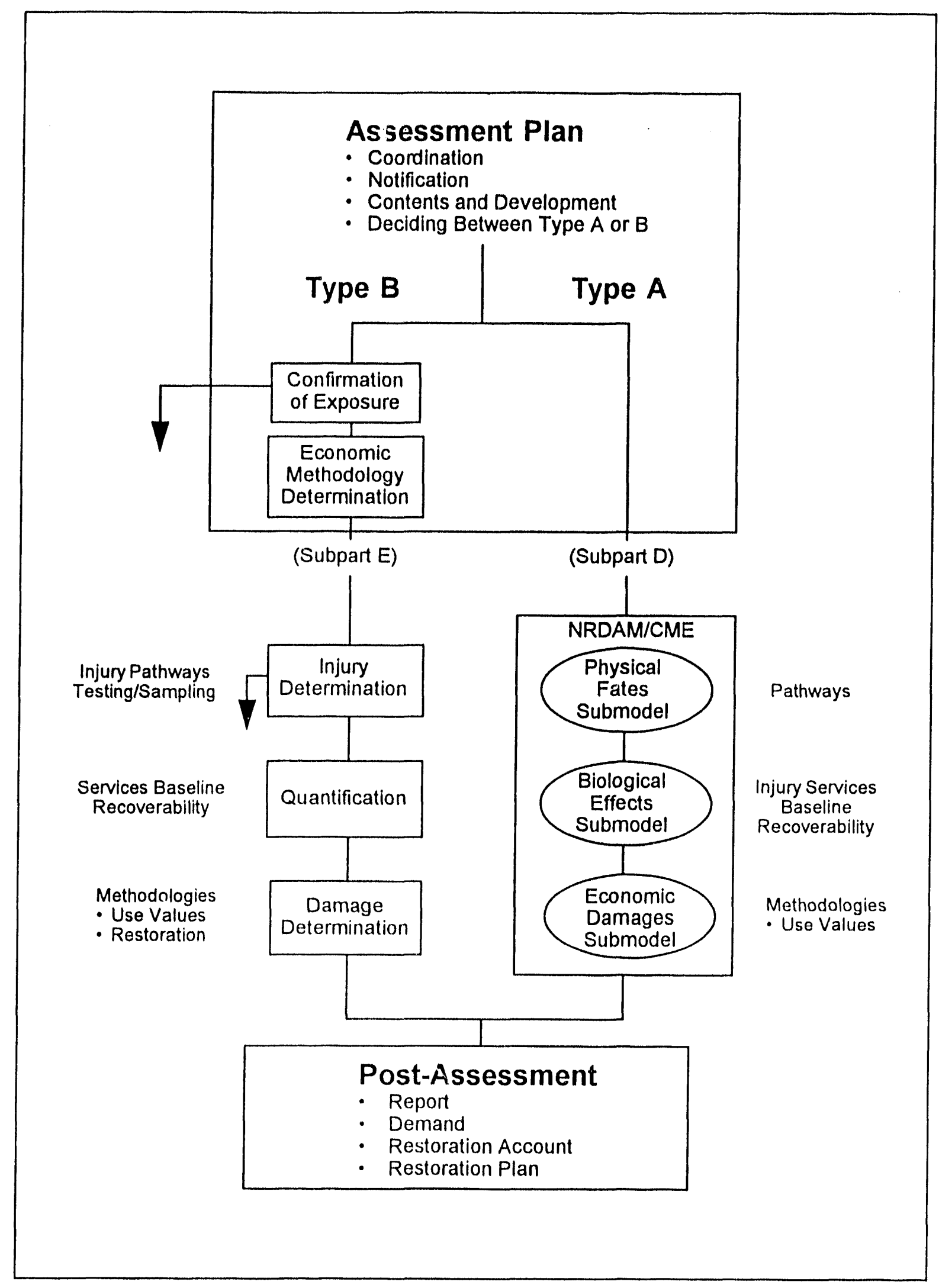

Exhibit 3-2:

DOI NRDA regulations under CERCLA 
seabirds; fur seals; and public beaches. All damages are present values computed over the period of resource recovery.

Despite this level of sophistication, there are several significant limitations to the NRDAM/CME model. The model is restricted to providing estimates of lost direct-use values, such as from tourism or fishing. The model does not currently develop an estimate of restoration costs, and it does not address non-use values. An attempt to validate the Type A model with a more detailed Type B assessment on the same scenario determined that the two approaches yielded results that differed by an order-of-magnitude, providing an indication of the relative precision of the two procedures (Grigalunas et al., 1992).

The DOI Type B Assessment usually consists of three steps: injury determination, injury quantification, and damages determination (Exhibit 3-2). ("Injury" generally means the physical destruction or impairment of a natural resource; "damage" refers to the monetary compensation for the injury). The injury definitions provide that an injury has resulted from the oil spill if a specified change in the physical or chemical quality of the resource is measured, based on standards established pursuant to earlier laws such as the Safe Drinking Water Act, Federal Water Pollution Control Act, and other laws. Thus, the regulations broadened past practice, under which many assessments relied primarily on the more conservative approach involving body counts of dead organisms as evidence of biological injury.

Injury quantification, the second step of a Type B assessment, provides the linkage between the injury and the economic measurement of damages. Natural resource "services" are defined as any function that one resource performs for humans or for another resource. Consequently, services under CERCLA include not only direct provision of food and recreation, but also flood control, ground water recharge and other indirect functions. Injury quantification is performed by establishing two basic parameters: baseline conditions and recoverability of the injured resource. The baseline level of services represents the conditions that would have existed had the oil spill not occurred (Exhibit 3-3, upper line). Often, this baseline data has not been established and a control area is used as an analogy. 
The second important procedure in injury quantification is determining the recovery profile of the resource over time (Exhibit 3-3 lower line). Remediation may accelerate natural recovery of the resource, setting the foundation for later restoration recovery, which again is more rapid than a purely natural recovery pace. The efficacy and justifiable cost of cleanup efforts to remediate injury caused by oil spills remains a highly controversial topic.

Damage determination, the third step of a Type B assessment, involves the estimation of the amount of money to be sought as compensation for the injury to the natural resources resulting from an oil spill. The economic methodologies under this assessment include restoration, the costs to restore or replace an injured resource to its baseline condition. In addition, several use-values methodologies are specified to measure the diminution of use values due to an oil spill. These include diminution in the market price of the resource where a reasonably competitive market exists. Alternative non-market methods contained in the Type $B$ assessment methodology include factor income, travel cost, hedonic pricing, and contingent valuation methodologies (discussed in Section 2). 


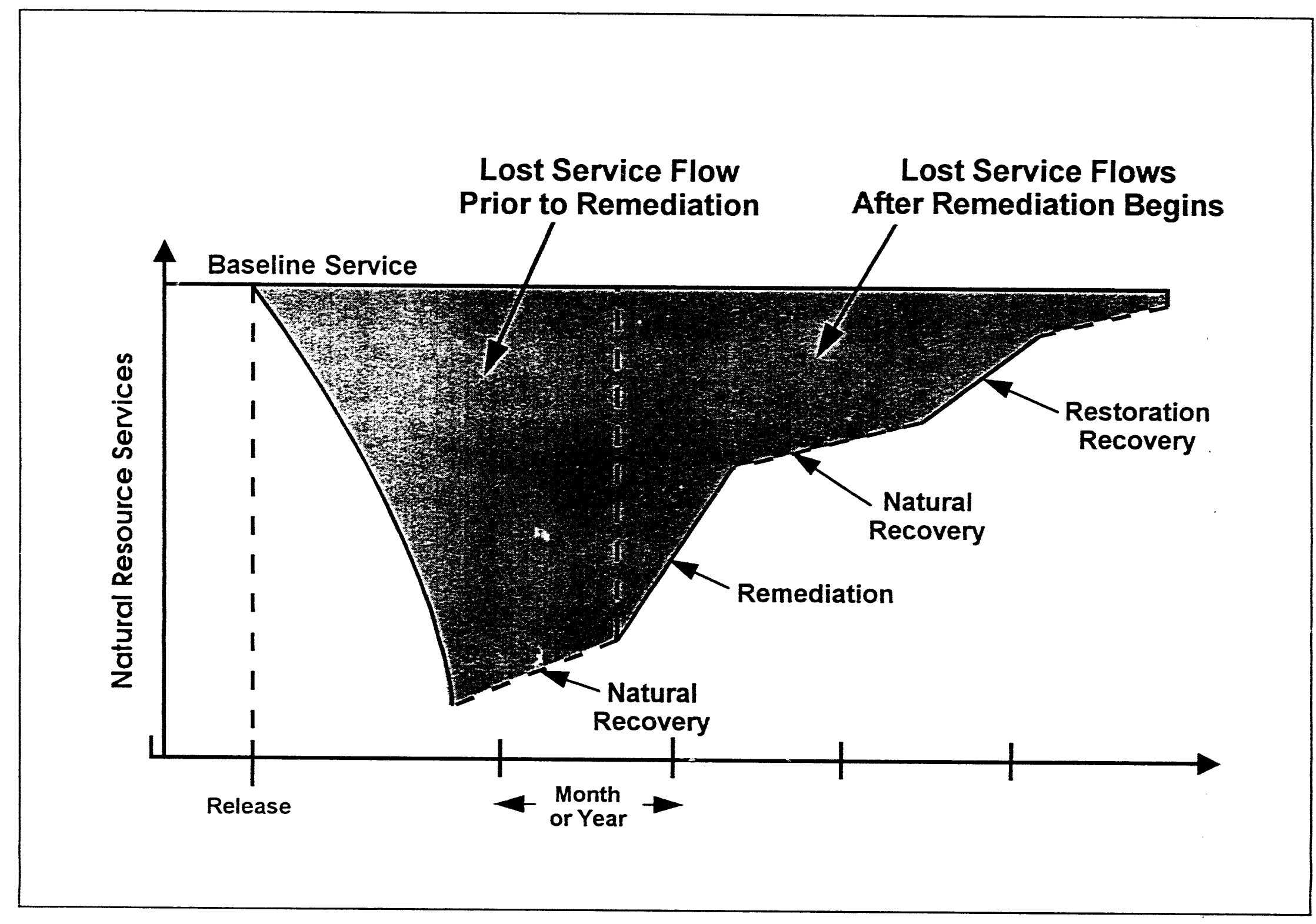

Exhibit 3-3:

Time profile of a generic one-time oil spill 


\subsection{State of Ohio v. Department of Interior (1989)}

The DOI damage assessment regulations were appealed by several states, environmental organizations and industry groups. The court specifically targeted two elements of the DOI regulations for revision: the "lesser of" rule, defining the measure of damages, and the hierarchy of valuation methods which ranked non-use damages below damages to direct use resources.

The DOI "lesser of" rule had limited liability for damages to the use value of a resource. which is often less than the cost to restore or replace the resource. For example, an oil spill that kills an entire seal rookery would under DOI regulations create damages of only $\$ 15$ per pelt, far less than the cost to restore or replace the rookery. DOI argued that economic efficiency supported the "lesser of" rule, because full restoration would be wasteful if the cost exceeds the value of the resource -- much as an insurance company would not pay $\$ 8,000$ to repair damage to a car worth $\$ 5,000$ prior to co!lision (State of Ohio v. DOI, 1989). However, the court determined that "Congress established a distinct preference for restoration costs as the measure of recovery in natural resources damage cases." Furthermore, the court ruled that Congress was skeptical of the possibility of measuring the true value of a natural resource, particularly if resources are not directly traded.

The second court objection was the hierarchy of valuation specified in the DOI regulations, particularly the either/or approach to use and nonuse values. The court noted that markets for most natural resource services are flawed or non-existent, and particularly objected that the use of contingent valuation (CV) was restricted only to damage assessments where no direct use values could be found. Whereas DOI had determined that CV is the least reliable methodology when used to measure non-use or the combination of use and non-use values, the court ruled that "DOI could just as easily said that CV was the most reliable," beciuse it is the only such method presently available.

In response to the State of Ohio v. DOI ruling, the DOI is currently modifying its Type A and Type B damage assessment regulations. The primary changes will involve shifting from the "lessor of" rule to full restoration costs in determining damages, and an increased importance 
of contingent valuation for measuring non-use values. Final versions of the DOI regulations are expected to be published in late 1993.

\subsection{Oil Pollution Act of $\mathbf{1 9 9 0}$}

The Oil Pollution Act of 1990 (OPA 90) expands the federal statutory liability for damages resulting from a discharge of oil into navigable waters, and is intended to provide compensation for a wider range of injuries than provided under CERCLA and CWA initiatives (Public Law 101-380, 1990). Momentum for passage of OPA 90 was largely generated by the 11-million gallon Exxon Valdez oil spill in Alaska, and three subsequent smaller oil spills which occurred within a 24-hour period in the coastal waters of Rhode Island, the Delaware River, and the Houston Ship Channel.

OPA 90 builds on the experience gained in the implementation of the Water Pollution Control Act (WPCA) and CERCLA, with which it shares similar provisions. OPA 90 applies to eligible oil spills which occurred after August 18, 1990. The essential provisions of OPA 90 which relate specifically to natural resource damage assessment are discussed in the following sections.

OPA 90 also covered regulations and research and development for oil spill prevention and remediation, which is a separate topic outside the focus of this report. Title VII of the Act established an Interagency Coordinating Committee on Oil Pollution Research, consisting of representatives of major government agencies concerned with oil pollution R\&D. The Act provides for research and development in innovative oil pollution technology, including: improved vessel design and operational practices; improved methods for recovery, removal, and disposal of spilled oil; improved environmental baseline data to help gauge the impacts of oil spills; and new methods for restoration and rehabilitation of natural resources damaged by oil discharges. In addition, OPA provides for research in economic methods of assessing natural resource damages due to oil spills, recognizing the imprecision and controversy which still surrounds most of the methods described in this report. 


\section{Natural R.esource 'Trustees}

Under OPA 90, the President, or authorized representative of any State, Indian tribe or foreign government on behalf of the public, is the assigned trustee of natural resources to present a claim and recover damages (Exhibit 3-4). The National Oceanic and Atmospheric Administration (NOAA) is vested through the Under Secretary of Commerce for Oceans and Atmosphere with responsibility of promulgating natural resource damage assessment regulations, which are discussed in Section 3.6. NOAA is required to consult with other "affected" agencies, such as DOE, in formulating these regulations.

\section{Liability}

Liability under OPA 90 involves two primary categories: removal costs and damages. Removal costs are the direct costs of containing and cleaning up the oil spill, whether incurred by tribal, local, State, or Federal government or by the operator. Removal costs are relatively straightforward to compute. The second type of liability is damage resulting from the oil spill, which can be much more diverse and controversial to determine.

Removal costs include any costs incurred by Federal and State governments or individuals consistent with the contingency plan drafted by the resource trustee. Response costs to contain and control an oil spill are not specifically identified in the Act as a covered removal cost or damage, but may be reasonably considered as a legitimate removal cost.

Damage Costs, not to be confused with punitive fines for negligence, are set forth in the OPA |section 1()()2(b)(2)|:

1) Natural resources: Damages for destruction to natural resoures are recoverable by a U.S. or other govermment trustee. The measure of natural resources damages will be [section 1002(b)(2)(A)]:
A) The cost of restoring, rehabilitating, replacing, or acquiring the equivalent of the damaged natural resources.
B) The diminution in value of those natural resources pending restoration; plus




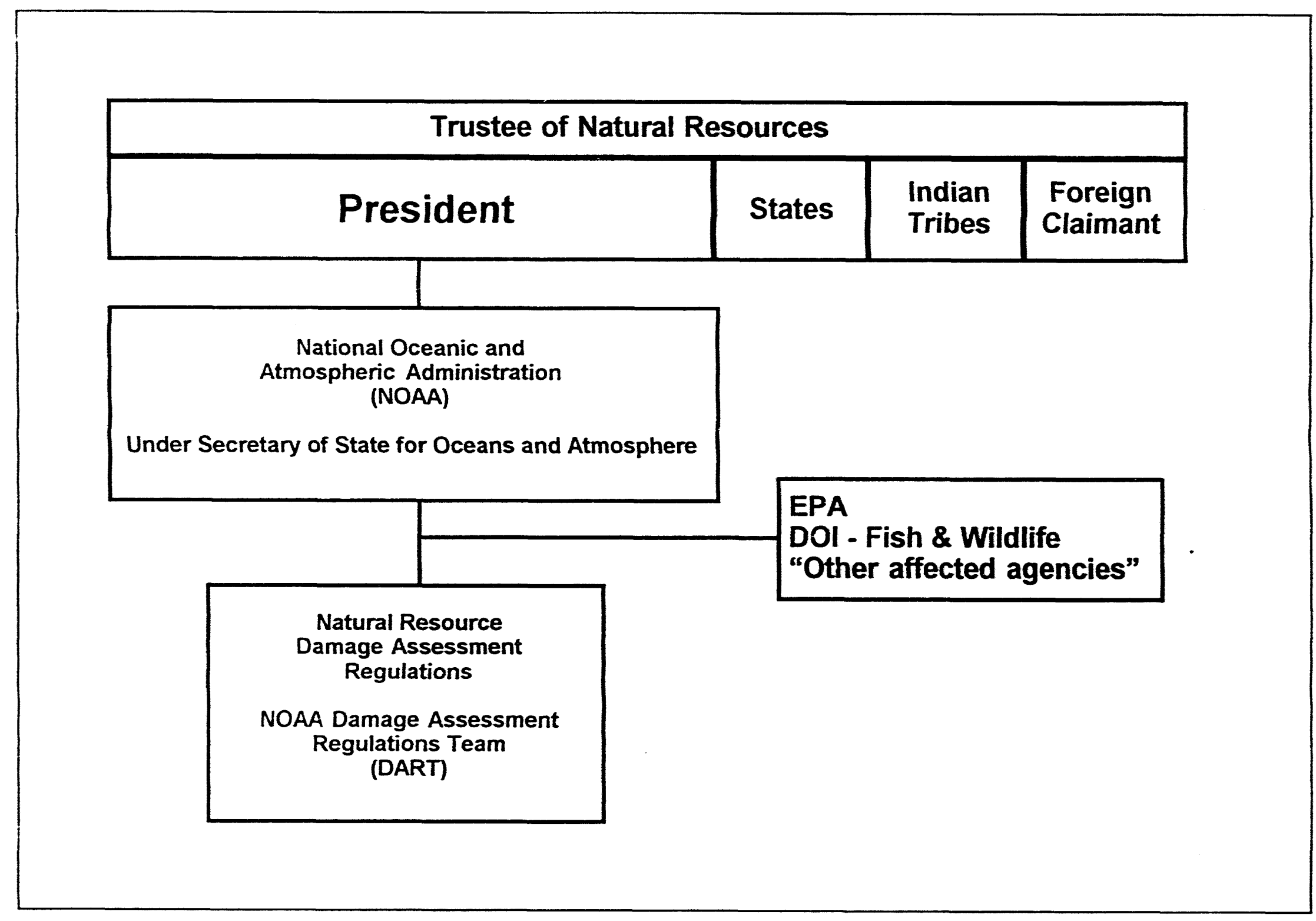

Exhibit 3-4:

Oil Pollution Act of 1990 - Natural resource damage assessment 
C) The reasonable cost of assessing those damages.

2) Real or personal property: Damages for economic losses resulting from destruction of real or personal property are recoverable by the owner of that property.

3) Subsistence use: Damages for the loss of subsistence use of natural resources are recoverable by any claimant reliant upon them, regardless of ownership of these resources.

4) Revenues: Damages are also recoverable by the federal or other government for the net loss of taxes, royalties, rents, fees, or net profits due to the destruction or injury to real or personal property, or to natural resources.

5) Profits and earning capacity: Damages equal to the loss of profits or impaiment of earning capacity due to the injury or loss of real or personal property, or natural resources may be recoverable by any claimant.

6) Public services: Damages for costs of providing additional public services, such protection from satety hazards, caused by an oil spill are recoverable by a State or local government.

\section{Measure of Damages}

Under OPA 90, trustees are required to conduct necessary assessments to estimate the cost of implementing the remediation plans, and to calculate the diminution in lost use and other injury pending restoration. The principle cost components of the remediation plan include restoration of the damaged natural resources, diminution in value of those natural resources pending restoration, and the reasonable costs of assessing the damages.

\section{I imits on Liability}

OPA 9() set the following limits on liability for four types of operations prone to oil spills. Note that these liabilities are linked to gross ton for vessels, rather than in actual volumes of oil spilled.

1) $\$ 1,200$ per gross ton for a tanker.

2) $\$ 600$ per gross ton for any other vessel.

3) $\$ 75$ million for an offshore facility, plus all removal costs.

4) $\$ 350$ million for any onshore facility and deepwater port. 
The President was required to report to Congress on the desirability of adjusting these limits of liability within 6 months following enactment of OPA 90, and from time to time thereafter. However, no changes in liability limits have been suggested to date. In addition, these initial liability limits are required to be adjusted not less often than every three years to reflect "significant" increases in the Consumer Price Index.

\section{Period of Limitations for Claimants}

OPA 90 established a period of limitations for claims resulting from an oil spill. Separate time constraints were established for removal cost claims and damage claims. All claims considered under the Act must be filed within these time limitations to be considered valid:

1) Removal Costs: Claims must be presented within 6 years following the date of completion of all removal (cleanup) actions for the oil spill.

2) Damages: Claims must be presented within 3 years following the linkage between the oil spill and the injury, such as by the natural resources damage assessment. This period is shorter than the removal cost limitations, probably because of uncertainty in linking natural resource damages to particular oil spills.

\subsection{NOAA Regulations (Proposed)}

Under OPA 90, NOAA was given two years to promulgate regulations for the assessment of natural resource damages from oil spills. Earlier regulations developed by DOI were specifically prohibited for calculating damage assessment. NOAA released the proposed regulations for review by other affected agencies in August 1993. Publication for public comment is expected to take place during the Fall of 1993, three years after enactment.

NOAA's proposed regulations, as provided to DOE, allow four alternative procedures which trustees may follow in assessing natural resource damages, depending on spill size and severity and type of damage. These methods include: the use of compensation formulae for small spills to calculate damages while incurring minimum assessment costs; a Type A model 
similar to DOI's Coastal and Marine Environments Model; an expedited damage assessment; and, a comprehensive damage assessment similar to but more sophisticated than DOI's Type B assessment.

Compensation formulae can be used if the oil discharge is 10 to 50,000 gallons and no significant loss in passive use values has occurred. Two separate formulae and accompanying schedules were developed: one for estuarine and marine environments, and one for inland (freshwater) waters. The formulae are available for use where the accurate quantification of injury and damages would not be cost-effective in the determination of the trustee.

Type A Model, developed originally by the U.S. Fish and Wildlife Service for Coastal/Marine Environments, may be used if judged to be compatible by the trustee, and if compensation formulas alone are not sufficient.

Expedited Damage Assessment (EDA) is to be used primarily for significant spills $(50,000$ to $1,000,000$ gallons) that do not affect highly sensitive resources or do not result in major losses of natural resource services (apart from these general guidelines, no specific examples of EDA application were provided in the proposed regulations). NOAA recommends the EDA procedure where neither compensation formulae nor the Type A Model are sufficient, where information on the nature of the discharge and its effect on natural resources and/or services is readily available, and where damages can be calculated by conducting limited analysis. The EDA should be considered where the costs of conducting a comprehensive damage assessment greatly exceeds the anticipated damages. The EDA approach falls between the DOI Type A and Type B models in sophistication, and is expected to be completed within two years from the date of discharge. Recreational, commercial, and ecologically important resource services are assessed, but passive use damages are not specifically addressed by the EDA methodology.

Comprehensive Damage Assessment (CDA) is to be used if the trustee determines that injury and damages resulting from the discharge can best be determined through a complex, prolonged process, involving a broad scope of injury determination and compensable values studies. A CDA is recommended for oil spills exceeding 1,000,000 gallons. In addition, a 
CDA should be conducted where potential restoration actions cannot be determined or implemented without determination of injury and compensable values. All damage determination methods listed in DOI Type B assessments are permitted, including contingent valuation.

\subsection{State of Washington Oil Spill Compensation Schedule}

In May 1992, the State of Washington implemented a simplified natural resource damage procedure for small- to moderate-sized oil spills in state waters (Geselbracht and Logan, 1993). Under these procedures, the damage assessment for qualifying spills is performed using a compensation schedule, which is based on formulae intended to capture both the vulnerability of the resource and the toxicity/longevity of the oil spill. As mandated by the state's Resource Damage Assessment Act, the per-barrel fines range from $\$ 1$ to $\$ 50$. Although the state's Department of Natural Resources has identified a total of 16 oil spills which are eligible for assessment using the new schedule, all these cases remain under judicial review and no data are publically available.

The purpose of Washington State's compensation schedules (much as for the NOAA compensation formulae) is to reduce the costs of the assessment, which for some oil spills have exceeded actual injuries by an order of magnitude. The schedule does not specify size lim 1 s for determining the applicability of oil spills: highly damaging oil spills may still be assessed using more thorough and costly methods.

The Washington State compensation tables are based on two primary factors: resource vulnerability rankings and an oil effects ranking. Resource vulnerability rankings were developed for seven types of important resources potentially affected by an oil spill. The "oil effects" rankings rate the potential for the oil spill to actually lead to injury of the resource, based on the chemistry and physical properties of the type of oil spilled. 


\section{Resource Vulnerability}

The resource vulnerability ranking is a measure of the susceptibility of various marine resources to damage from an oil spill. The ranking is a composite of individual ratings developed for seven categories of marine resources: 35 types of marine and estuarine habitats, marine bird populations, 61 species of commercially or recreationally harvested marine fish, 38 species of harvested shellfish, salmon species and ages, 15 marine mammal species, and various recreational attributes. Seasonality also affects each of the individual resource vulnerability rankings. Finally, damages are directly proportional to the area of impact for each individual resource class. Vulnerability of each resource is ranked, with 1 indicating the least vulnerable condition and 5 representing the most vulnerable.

Each type of resource vulnerability ranking was developed by the state in consultation with an advisory committee comprising resource experts from state and federal agencies, academia, consulting firms, Indian tribes, and environmental organizations. Industry input was limited to public comment on the proposed rule. The schedules do not consider passive non-use natural resource values, such as option and existence values.

\section{Oil Effects Rankings}

The oil effects rankings rate the relative potential of spilled oil to cause three types of harmful impacts on natural resources: acute toxicity, mechanical injury, and environmental persistence. These three effects were rated for five types of crude oil or products which account for $90 \%$ of the oil shipped through state cristal waters. The rankings rate the relative severity of damage caused by the oils, with 1 representing a potential for the least injury, and 5 representing a potential for maximum injury (Exhibit 3-5).

Toxicity was based on solubility and weight-fraction of i-ring aromatic hydrocarbons in the spilled oil, rather than any empirical evidence of oil toxicity.

Mechanical injury, caused primarily by coating and smothering, was assumed to vary inversely with API gravity, based on empirical evidence. Therefore, higher density oils were ascribed a higher (more severe) rating. 
Persistence of the oil in the environment, because of a lack of empirical data, was simply ranked by an "educated guess" approach: a 1 ranking for persistence of days to weeks for gasoline, up to a 5 ranking for persistence estimated at 5 to 10 years or more for crude oil.

Exhibit 3-5:

Oil effects rankings under State of Washington damage schedule

\begin{tabular}{||l|c|c|c|}
\hline \multicolumn{1}{|c|}{ Type of Oil Product } & $\begin{array}{c}\text { Acute Toxicity } \\
\text { Rank }\end{array}$ & $\begin{array}{c}\text { Mechanical } \\
\text { Injury Rank }\end{array}$ & $\begin{array}{c}\text { Persistence } \\
\text { Rank }\end{array}$ \\
\hline \hline Prudhoe Bay Crude Oil & 0.9 & 3.6 & 5.0 \\
\hline Bunker C & 2.3 & 5.0 & 5.0 \\
\hline No. 2 Fuel Oil & 2.3 & 3.2 & 2.0 \\
\hline Gasoline & 5.0 & 1.0 & 1.0 \\
\hline Kerosene/Jet Fuel & 1.4 & 2.4 & 1.0 \\
\hline
\end{tabular}

\section{Damages}

Damages under the Washington State schedule are computed based on a formula which incorporates both the resource vulnerability rankings and the oil effects rankings. First, the individual resource vulnerability rankings are simply added together to produce a single spill vulnerability score (SVS) for each oil effect, as in formula (1):

(1) SVS $_{i}=\mathrm{HVS}_{\mathrm{i}}+\mathrm{BVS}+\mathrm{MFVS}+\mathrm{SFVS}+\mathrm{SAVS}+\mathrm{MVS}+\mathrm{RVS}$

Where: $\quad$ SVSi $=$ Spill vulnerability for oil effect $\mathrm{i}$

HVSi $=$ Habitat vulnerability to an oil spill's propensity to cause effect $i^{1}$

i $=$ Oil effect (toxicity, mechanical injury, or persistence)

BVS = Marine bird vulnerability rating

MFVS $=$ Marine fisheries vulnerability rating

SFVS $=$ Shellfish vulnerability rating

SAVS $=$ Salmon vulnerability rating

MVS = Marine mammal vulnerability rating

RVS $=$ Recreation vulnerability rating

1 Ranked on scale of 1 to 5 , based on magnitude of resources at risk (hm) and sensitivity to the acute, mechanical, and persistence effects of spilled oil $\left(\mathrm{hs}_{\mathrm{i}}\right)$. 
Finally, the spill vulnerability scores for each oil effect $\left(\mathrm{SVS}_{\mathrm{i}}\right)$, the oil effects scores $\left(\mathrm{OIL}_{\mathrm{i}}\right)$, and the size of the oil spill (gallons) are factored into the damage calculation formula (2):

$$
\operatorname{Damages}(\$)=\text { spill size } \times 0.1\left[\left(\mathrm{OIL}_{\mathrm{Al}} \times \mathrm{SVS}_{\mathrm{AT}}\right)+\left(\mathrm{OIL}_{\mathrm{Ml}} \times \mathrm{SVS}_{\mathrm{MI}}\right)+\left(\mathrm{OIL}_{\mathrm{r}} \times \mathrm{SVS}_{\mathrm{p}}\right)\right]
$$

Where: $\quad$ SVS $=\quad$ Spill vulnerability rating for acute toxicity (AT), mechanical injury (ME), and persistence (P).

OIL $=\quad$ Oil effect rating for acute toxicity (AT), mechanical injury (ME), and persistence $(\mathrm{P})$.

$0.1=\quad$ Multiplier to adjust damages

\section{Critical Analysis}

The Washington State oil spill compensation schedule is one of the first attempts to develop a simplified approach to natural resource damage assessment, which would permit significant savings in assessment costs. Because assessment costs under OPA 90 must be paid by the responsible party, the schedule can potentially save operators considerable costs. However, there are several possible areas where this schedule is a poor approximation of actual spill damages:

1) The oil effects rankings, one of the two major components of the damage formula, are mostly based on educated guesses of the toxicity and persistence of spilled oil. Although these rankings are probably qualitatively correct, because they are not based on empirical evidence there may be an order of magnitude of error in the absolute value of the effects, leading to an equal potential error in damages. Empirical observation of oil effects for each resource, which is not currently available, is the only objective method of determining this information.

2) Rather than placing a value on individual marine species and other resources, the schedule rates the value of each of the seven resource categories as equal. For example, fishing, marine mammals, and recreation are all given equal value, regardless of actual market or non-market values. 


\subsection{Florida Natural Resource Damage Compensation Schedule}

In 1992, the same year as the Washington State regulations were published, Florida enacted a similar approach to formulaic compensation of natural resource damages from oil spills (Plante et al., 1993). Like Washington's law, the Florida schedule sets out a formula for calculating damages based on the amount and type of spill, the spill's location and areal extent, and the type of resource affected. The schedule may be used to determine damages from oil spills of up to 30,000 gallons. The formula for compensation was based on the cost of restoring resources to their pre-spill condition and on the value of lost use of damaged resources between injury and restoration.

Oil effects rankings were developed for various oil products based on toxicity, persistence, and other characteristics, similar to the Washington State approach.

Resource vulnerability was determined for a variety of habitats in state waters, again generally similar to the Washington State schedule.

Damages were determined according to the following formula, which involves both oil effects and resource vulnerability rankings:

$$
\text { Damage }=\{B \times V \times L \times S M A+A\} \times P C+E T S+A C
$$

Where: $\mathrm{B}=$ Base rate of $\$ 1$ per gallon

$\mathrm{V}=$ Volume of pollutant in gallons

$\mathrm{L}=$ Location factor -- 8 for inshore, 5 for nearshore, and 1 for offshore

SMA $=$ Special management area factor -2 for state parks, wildlife refuges and other protected areas.

$\mathrm{A}=$ Additive dollar amount for impacted habitat, times the SMA factor ( $\$ 10 / \mathrm{ft}^{2}$ for coral reef, $\$ 1 / \mathrm{ft}^{2}$ fur mangroves, $\$ 0.05 / \mathrm{ft}^{2}$ for sandy bottom.

PC = Pollutant characteristic factor $--8,4$, or 1 depending on toxicity, solubility, persistence, and dispersibility.

ETS = Damage compensation for death of endangered species -- $\$ 10,000$ each

$\mathrm{AC}=$ Administrative costs of conducting damage assessment. 
Florida's approach differs from that of Washington State in several important ways:

1) The Florida trustee is allowed somewhat greater latitude in assigning oil effects rankings.

2) Florida's resource vulnerability range is more circumscribed than Washington's, with an 8-fold potential variation in damages, compared with a 35 -fold potential variation under the Washington schedule (which has 7 resource categories, each ranked 1 to 5 ).

3) Administrative costs, not counted in Washington's schedule, are included under Florida's assessment approach. This generates a potential disincentive to minimize assessment costs, the primary purpose of the schedule.

Sections 2 and 3 of this report provide an overview of the methodologies and regulatory framework, respectively, for natural resource damage assessment. The remainder of this report focuses on specific case studies of natural resource damages resulting from oil spills. 


\section{Critical Analysis of Natural Resource Damage Assessments}

\subsection{Overview}

To determine the economic impacts of oil spills, eight case studies from three spillprone components of the oil supply system were examined: tankers/barges, pipelines/refineries, and offshore production facilities (Exhibit 4-1). For each case study, all publically available assessments quantifying response and cleanup costs and natural resource damages resulting from the oil spill were compiled. Where available, information on indirect, non-use damages caused by oil spills was integrated with more plentiful data on direct use impacts. The methodology and results of these assessments were critically reviewed to develop a most likely range in oil spill impacts. Where information was available, impacts were characterized by affected industry, government, or other group. Finally, economic impacts were normalized to spill size, to develop spill unit values to permit comparison among cases.

Due to the mobility of tankers, tankers spills can cause the highest spill unit cost values (as well as the widest range), depending on cleanup conditions and the environmental characteristics of the spill location. Pipeline and refinery spills caused the next highest (and more uniform) spill unit cost values, primarily because they frequently are located in sensitive wetland environments where cleanup is costly and natural resource damages are significant. Spills from offshore production facilities were determined to cause the lowest spill unit cost values, although information from this type of spill is limited and out of date.

A total of four tanker spill case studies are analyzed in Section 4.2. Tanker spills caused widely varying unit spill costs. The S.S. Glacier Bay spill in Cook Inlet, Alaska resulted in very high damages to commercial fishing, but relatively modest other use and non-use costs. The Exxon Valdez spill, in contrast, created the highest non-r'se natural resource damages on record, with relatively modest spill unit cost values for direct use damages. The Amazon Venture oil spill in the Savannah River caused very low unit cleanup and natural resource damages. The Mercer data base of four tanker spill settlements showed natural resource damages ranging from $\$ 4.15$ to $\$ 35.71$ per gallon. 
Two pipeline/refinery spills are discussed in Section 4.3. The Exxon Arthur Kill pipeline spill in Staten Island, and the Texaco Anacortes refinery spill near the Puget Sound, Washington. Finally, the 1969 Santa Barbara oil spill and the 1979 Ixtoc spill are analyzed to provide information on ofishore production facilities in Section 4.4. Although these offshore platform spills predate significant oil spill legislation and occurred prior to the development of many natural resource damage estimation methods, they are the only significant offshore spills for which cost data are available. 
Exhibit 4-1: Overview of oil spills analyzed

\begin{tabular}{|c|c|c|c|c|c|c|}
\hline & $\begin{array}{c}\text { Year of } \\
\text { Spill }\end{array}$ & $\begin{array}{c}\text { Volume } \\
\text { Spilled (gal) }\end{array}$ & Oil Type & Location & Environment & $\begin{array}{l}\text { Regulatory } \\
\text { Framework }\end{array}$ \\
\hline \multicolumn{7}{|l|}{ Tanker } \\
\hline Glacier Bay & 1987 & 183,162 & Crude & Cook Inlet, AK & $\begin{array}{l}\text { Protected } \\
\text { Bay }\end{array}$ & CERCLA \\
\hline Exxon Valdez & 1989 & 10.8 Million & Crude & $\begin{array}{l}\text { Prince William } \\
\text { Sound, AK }\end{array}$ & $\begin{array}{l}\text { Protected } \\
\text { Bay }\end{array}$ & CERCLA \\
\hline Amazon Venture & 1986 & 500,000 & No. 6 fuel oil & Savannah River, GA & River & CERCLA \\
\hline World Prodigy & 1989 & 289,000 & No. 2 fuel oil & Rhode Island & $\begin{array}{c}\text { Protected } \\
\text { Bay }\end{array}$ & CERCLA \\
\hline \multicolumn{7}{|l|}{ Pipeline/Refinery } \\
\hline Exxon Arthur Kill & 1990 & 567,000 & No. 2 fuel oil & Staten Island, NY & $\begin{array}{l}\text { Industrial } \\
\text { wetland }\end{array}$ & CERCLA \\
\hline Texaco Anacortes & 1991 & 210,000 & Crude & Puget Sound, WA & $\begin{array}{l}\text { Industrial } \\
\text { wetland }\end{array}$ & OPA 90 \\
\hline \multicolumn{7}{|l|}{ Offshore Platform } \\
\hline Ixtoc & 1979 & 139 million & Crude & Gulf of Mexico & OCS & NCP \\
\hline Santa Barbara & 1969 & 420,000 & Crude & $\begin{array}{l}\text { Coastal } \\
\text { S. California }\end{array}$ & OCS & OCSLA \\
\hline
\end{tabular}




\subsection{Tanker Spills}

\subsubsection{Exxon Valdez (Prince William Sound, Alaska)}

\section{Introduction}

On March 24, 1989, the tanker Exxon Valdez ran aground about 25 miles south of Valdez in Alaska's Prince William Sound, spilling an estimated 10.8 million gallons of North Slope crude oil. This catastrophe was one of the largest and most damaging spills on record, affecting a wide r.nge of industries, such as tourism and fishing, and causing considerable impacts on subsistence uses, wildlife, and (according to one study) passive use damages affecting the entire U.S. population.

Approximately 350 miles of shoreline within Prince William Sound, a protected and environmentally sensitive body of water, were oiled to varying extents during the spill, of which 40 to 50 miles could be classified as moderately to heavily oiled (Dean et al., 1993). The extent of shoreline affected by the oil spill amounted to $15 \%$ of the total Prince William Sound shoreline, with $3 \%$ of the total shoreline moderately to heavily oiled (Exhibit 4-2).

A number of studies are available quantifying cleanup and natural resource damages resulting from the Exxon Valdez oil spill. Most of the studies cited in this section were performed on behalf of the Alaska Attorney General's Office to determine damages related to the state and federal case against Exxon Corp., Exxon Shipping Co., and the Alyeska Pipeline Service Co, and its owners. Some of these studies are preliminary or do not take the final step of assessing the dollar value of physical injuries. Consequently, although the Exxon Valdez case study contains more detail than for any other case analyzed, the analysis remains only a preliminary assessment of the complex natural resource damages resulting from the Exxon Valdez oil spill.

In January 1992, Exxon agreed to a reported $\$ 1.125$ billion settlement with Alaska and federal government trustees for damage claims caused by the spill (Ward and Duffield, 1992), the largest single environmental settlement in history. The magnitude of this settlement, far 


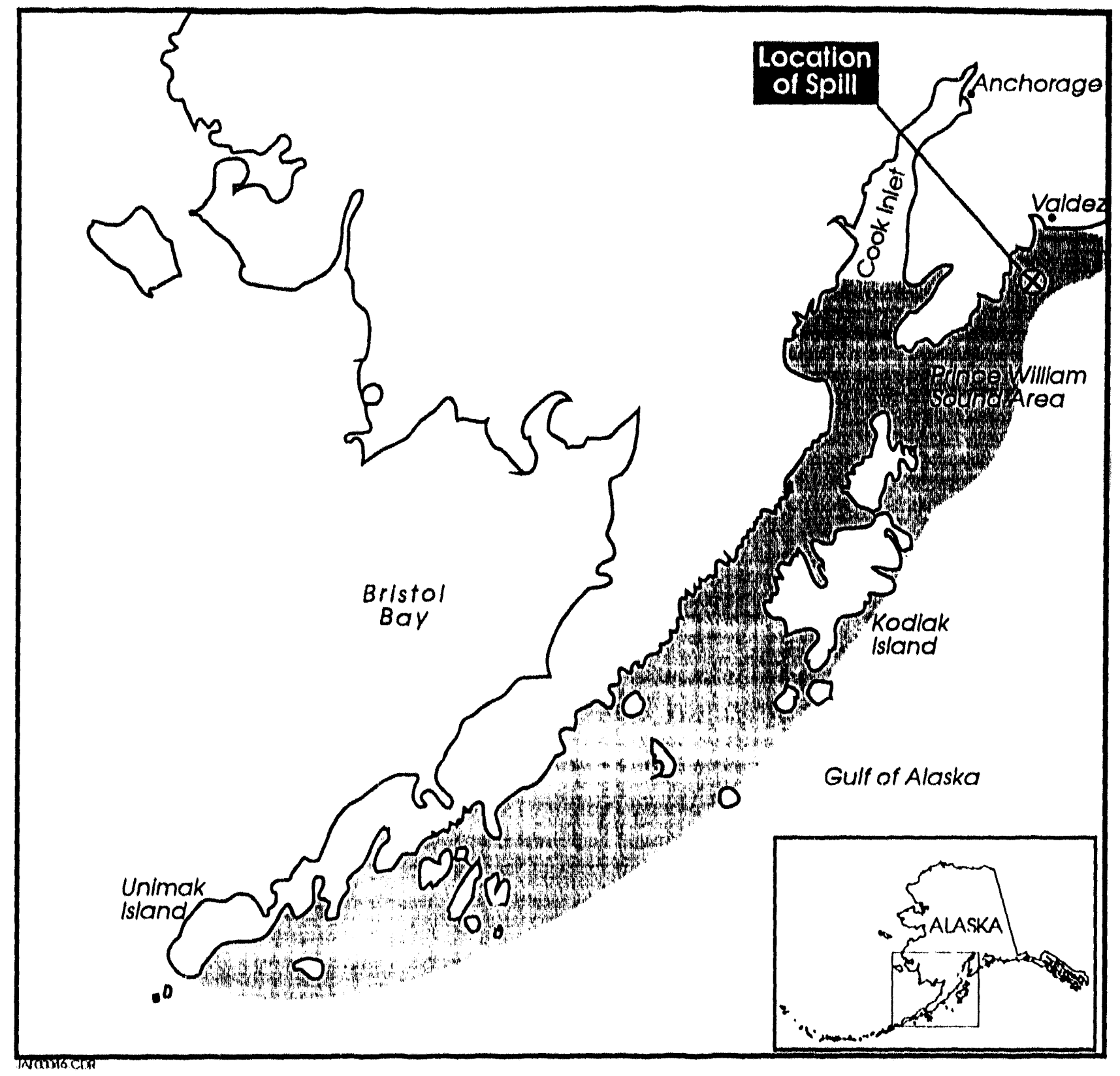

Exhibit 4-2:

Map of the Exxon Valdez oil spill area (spill impacts not uniform).

higher than calculated direct use damages, indicates that passive non-use values were implicitly agreed to by Exxon. Some private civil claims remain in litigation, which has slowed the release of spill cost and damage information to the public.

\section{Response and Cleanup Costs}

Under OPA 90, trustees are permitted to recover all costs of responding to and cleaning up an oil spill. Only general information on response and cleanup costs was available for the Exxon Valdez oil spill. Exxon, other industry groups, and government together are estimated 
to have spent a total of about $\$ 2.8$ billion (1993\$) on direct cleanup of the oil spill (calculated from Mercer, 1992). Cleanup costs amounted to approximately $\$ 260$ per gallon spilled, the largest single cost category related to the spill (69\% of combined costs and damage settlement), and exceeding settled natural resource damages paid to government trustees (exhibit 4-3). Unit costs for cleanup operations greatly exceeded those from other oil spills, which generally ranged from $\$ 20$ to $\$ 40$ per bbl. Exxon's cleanup costs were so high because of the environmental sensitivity of the spill location and the high mobilization and labor costs encountered in the remote cleanup site.

\section{Capital Losses}

The Exxon Valdez spill resulted in sizeable direct capital losses, mainly lost oil and damage to the ship. However, these losses account for only a very small proportion of total damages caused by the spill. The estimated 10.8 million gallons of oil lost in the accident was worth approximately $\$ 0.36 / \mathrm{gal}$ at the time and location of the loss, for a total damage of $\$ 3.86$ million (Exhibit 4-3). Ship repair costs, and the opportunity costs of ship downtime during repair, have not been publically reported but were probably substantial.

\section{Natural Resource Damages}

The Exron Valdez oil spill adversely impacted a wide range of natural resource services in south-central Alaska. Information was available on natural resource damage assessment costs, and damages to commercial and sport fisheries, tourism, and wildlife. In addition, a contingent valuation survey of non-use natural resource damages caused by the oil spill was available. All of these assessments were performed on behalf of government resource trustees; no damage assessments funded by Exxon or independent groups have been publicly released. 


\section{Exhibit 4-3:}

Summary of estimated costs and damages (top) and actual settlement due to the Exxon Valdez oil spill (Brown, 1992; Carson \& Hanemann, 1992; Carson et al., 1992; Harrison, 1991; McDowell Group, 1990; Mercer, 1992).

\begin{tabular}{|c|c|c|c|c|c|c|c|c|}
\hline & \multirow{2}{*}{$\begin{array}{l}\text { Cleanup } \\
\text { Costs }\end{array}$} & \multirow{2}{*}{$\begin{array}{l}\text { Lost Oil } \\
\text { Value }\end{array}$} & \multirow{2}{*}{$\begin{array}{c}\text { NRDA } \\
\text { Assessment } \\
\text { Costs }\end{array}$} & \multicolumn{2}{|c|}{ Direct Use Damages } & \multicolumn{2}{|c|}{ Non-use Damages } & \multirow[b]{2}{*}{ Total* } \\
\hline & & & & $\begin{array}{l}\text { Commre'l } \\
\text { Fishing }\end{array}$ & $\begin{array}{l}\text { Tourism/ } \\
\text { Sport } \\
\text { Fishing }\end{array}$ & $\begin{array}{c}\text { Wildlife } \\
\text { Rehabilitation* }\end{array}$ & $\begin{array}{c}\text { Existence } \\
\text { Option, Etc. }\end{array}$ & \\
\hline \multicolumn{9}{|l|}{ Estimated Damages } \\
\hline $\begin{array}{l}\text { TOTAL } \\
\text { (Millions \$) } \\
\text { Various Years }\end{array}$ & 2,300 & 3.86 & $100-200$ & 76.0 & 50.0 & 48.2 & 2,800 & $5,378-5,478$ \\
\hline $\begin{array}{l}\text { TOTAL } \\
\text { Million (1993 \$) }\end{array}$ & 2,780 & 4.31 & $107-214$ & 91.9 & 55.8 & 53.9 & 3,000 & $6,093-6,200$ \\
\hline $\begin{array}{l}\text { PER GALLON } \\
(1993 \$) \\
\end{array}$ & 257 & 0.40 & $9.91-19.81$ & 8.51 & 5.16 & 4.99 & 278.00 & $564-574$ \\
\hline $\begin{array}{l}\text { Actual Settlement } \\
\text { \& Expenditures }\end{array}$ & & & \multicolumn{3}{|c|}{ NRD Settlement } & $\begin{array}{c}\text { Wildlife } \\
\text { Rehabilitation }\end{array}$ & & \\
\hline $\begin{array}{l}\text { TOTAL } \\
\text { Million \$ } \\
\text { Various Years }\end{array}$ & 2,300 & 3.86 & \multicolumn{3}{|c|}{1,125} & 45 & & 3,474 \\
\hline $\begin{array}{l}\text { TOTAL } \\
\text { Million (1993 \$) }\end{array}$ & 2,780 & 4.31 & \multicolumn{3}{|c|}{1,158} & 50.2 & & 3,993 \\
\hline $\begin{array}{l}\text { PER GALLON } \\
(1993 \$)\end{array}$ & 257 & 0.40 & \multicolumn{3}{|c|}{107} & $4.6 ?$ & & 370 \\
\hline
\end{tabular}




\section{NRDA Assessment Costs}

Under OPA 90, in addition to response/cleanup costs and natural resource damages, trustees are also permitted to recover reasonable costs of assessing natural resource damages. Because the Exxon Valdez spill occurred prior to passage of OPA, the costs incurred by government trustees to assess natural resource damages related to the spill have not yet been rigorously examined. A published NOAA estimate placed total damage assessment costs incurred by government at approximately $\$ 100$ million, and speculated that Exxon had spent a comparable amount in developing its defense case (Luthi et al., 1993; Exhibit 1-3).

\section{Commercial Fishing}

A comprehensive study of losses to the commercial fishing industry is still in progress by the State of Alaska Attorney General's office. Claims to July 1, 1993 for lost or damaged catch, gear and boats fouled by oil, have totaled $\$ 76$ million (Exhibit 4-3; personal communication, Alaska Attorney General's Office, October 11, 1993).

\section{Sport Fishing}

As with other oil spill impacts, recreational uses -- particularly sport fishing -- provide the best opportunity for rigorous damage assessment. The Alaska Department of Fish and Game (ADFG), which for many years had collected detailed baseline data on economic benefits of recreational fishing, issued a report documenting changes in recreational fishing patterns due to the Exxon Valdez oil spill (Mills, 1992). Based on these changes in recreational fishing behavior, Carson and Hanemann (1992) conducted a study assessing the cost of these changes using travel cost methodology.

The ADFG study utilized questionnaires mailed to random purchasers of fishing licenses. ADFG had been performing similar surveys annually since 1979 , establishing a standardized sampling system; thus a good baseline of data was available for comparison with post-spill impacts. ADFG defined a baseline as the period 1984 to 1988 , during which recreational fishing increased annually by about $10 \%$ (Exhibit 4-4). 
The Carson and Hanemann valuation study determined that a wide range of damage estimates were obtained depending on alternative assumptions. Four key factors were identified as having the most important impact on damage estimates, including:

Treatment of the baseline year. By adopting 1987 as the base year, rather than 1988 or a multi-year temporal trend, no economic losses in recreational fishing would be calculated due to the oil spill. However, such an approach would not be reasonable since fïshing had been steadily increasing at about $10 \%$ per year during the mid-1980's. Similarly, extrapolating the unusually (and apparently unsustainably) large jump in fishing use that occurred between 1987 and 1988 to develop 1989 levels in the absence of an oil spill would lead to unreasonably high damages to recreational fishing. Instead, the Carson and Hanemann study projected the 1984-1988 trend to infer 1989 fishing levels without the oil spill.

Trend in sport fishing activities. Different types of fisheries have different dollar values associated with their closure or reduction in quality. For example, a Kenai king salmon fishing trip is worth an order of magnitude more than many other types of fishing trips in Alaska. For every loss of a high-value fishing day, there may have been many more fishing trips which took place at less desirable sites. Carson and Hanemann considered this factor in assigning travel costs.

Trips taken by oil spill cleanup workers. The ADFG data show that the number of non-residents sport fishing in south-central Alaska increased in 1989, despite the overall sharp drop in total fishing that year. The most likely explanation is the presence of a large number of spill cleanup workers in the spill area, many of whom took the opportunity to fish. This trend acted to reduce the number of fishing days lost as well as the estimated damages.

Daily values. Daily values for sport fishing estimated by Carson and Hanemann based on travel cost methodology ranged from $\$ 204$ to $\$ 300$ per day, with a mean estimate of $\$ 250$. These values represent the value of fishing activity in south-central Alaska, based on willingness to travel. 


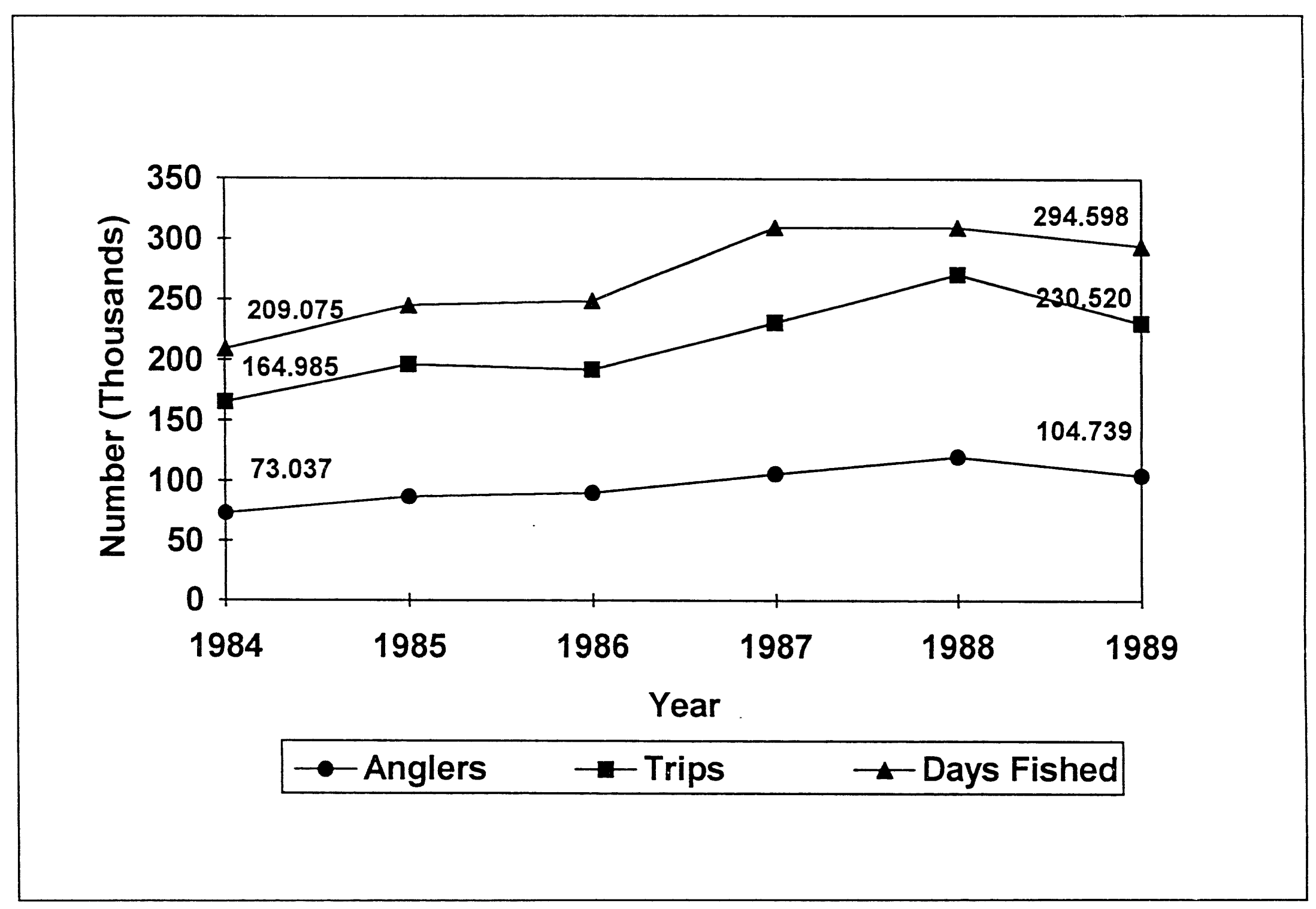

Exhibit 4-4:

Sport fishing effort for the Exxon Valdez oil spill area, 1984 - 1990 (Mills, 1992). 
Carson and Hanemann developed three alternative estimates for damages to recreational fishing due to the Exxon Valdez oil spill (Exhibit 4-5).

1) A low estimate was developed assuming 1988 as a base year, with no temporal increase in fishing; ignoring whether households participated in the oil spill cleanup; and valuing days lost due to the Exxon Valdez oil spill at a conservative $\$ 204$ per day, which ignores the large fraction of high-value halibut and silver salmon fish days. This calculation yields a lower bound damage of $\$ 3.7$ million.

2) A high estimate was developed assuming a simple trend regression using pre-1989 data to quantify lost fishing days; and using a higher $\$ 300$ per day rate to reflect the loss of higher valued salmon and saltwater fisheries. This calculation determined an upper bound damage to sport fishing of $\$ 50.5$ million.

3) A central estimate of recreational fishing damages was determined using a regression of pre-1989, but with half of fishing performed by cleanup households and half by visitors from outside south-central Alaska; and using an intermediate $\$ 250$ per day lost value. This intermediate calculation produced a damage estimate of $\$ 31$ million.

Exhibit 4-5:

Estimates of damages to recreational fishing due to the Exxon Valdez oil spill (Mills, 1992; Carson and Hanemann, 1992)

\begin{tabular}{|l|c|c|c|c|}
\cline { 2 - 5 } & $\begin{array}{c}\text { Reduction in } \\
\text { Fishing Days }\end{array}$ & $\begin{array}{c}\text { Daily Travel } \\
\text { Cost Value }\end{array}$ & Damages & $1993 \$$ \\
\hline \hline Lower Bound & 17,923 & $\$ 204$ & $\$ 3.7$ million & $\$ 4.1$ million \\
\hline Central Case & 124,185 & $\$ 250$ & $\$ 31.0$ million & $\$ 34.6$ million \\
\hline Upper Bound & 168,196 & $\$ 300$ & $\$ 50.5$ million & $\$ 56.4$ million \\
\hline
\end{tabular}

Tourism

A very preliminary assessment of the impact of the Exxon Valdez oil spill on the Alaskan tourism industry, dating to August 1990, was performed for the State of Alaska by the Juneaubased consulting firm McDowell Group. This study showed that visitor spending during the summer of 1989 decreased $8 \%$ in south-central Alaska and $35 \%$ in southwestern Alaska 
(including the lightly visited Aleutian Islands) from 1986 levels, resulting in a loss of $\$ 19$ million in visitor spending. Visitor spending in other parts of the state did not increase enough to make up for this regional decline. This study may have understated true losses in simply comparing 1989 to 1986 levels, rather than to a projected multi-year baseline. In addition, the study reported only Summer visitor data; visitor losses during the Fall and Winter of 1989 were not included, but are likely to have been small.

Other qualitative market research showed that the oil spill had left a lasting negative impression on potential visitors. In addition, shortages of labor appeared in the tourism industry due to temporary higher-paying cleanup jobs following the spill, which led to higher costs to consumers and to the tourist industry. Nevertheless, normal visitor patterns resumed during 1990 following cleanup of the oil spill and no permanent damage to the tourism industry appears to have occurred.

\section{Wildlife}

No comprehensive study is publicly available documenting the economic impacts of the Exxon Valdez oil spill on non-commercially harvested wildlife. However, ARI has developed a preliminary estimate of wildlife damages based on two separate studies of wildlife injuries, which provide the major components for computing damages. In a study for the Alaska Attorney General, a University of Washington biologist estimated unit replacement values for birds and mammals affected by the Exxon Valdez oil spill (Brown, 1992). These unit values were then multiplied by the estimate of wildlife killed cited in Carson et al., 1992, which was assumed to be representative of the widely ranging estimates that have been made of wildlife killed by the spill. This simple computation yielded an estimate of $\$ 53.9$ million for total wildlife damages (Exhibit 4-6). (In comparison, Exxon reported spending over $\$ 45$ million for rescue and rehabilitation of sea otters and birds (Harrison, 1991)).

The estimated unit values for wildlife were based on the costs of relocation, replacement, and rehabilitation for some of the shorebirds, seabirds, and marine and terrestrial mammals that suffered injury or were killed (Brown, 1992). Information on animal costs came primarily from 
professional animal-locating firms that work for zoos and private individuals, primarily because most of these animals are not the source of large direct-use values, such as hunting.

Because the Exxon Valdez spill was not subject to OPA 90, it is not likely that Exxon would be responsible for replacing all the animals killed by the oil spill. However, this number was estimated for the purposes of the present study to determine total costs under OPA, because the new law specifically requires the replacement of damaged resources.

1) Sea otters. The largest numerical loss of marine mammals due to the Exxon Valdez spill occurred to the sea otter population. Market prices for sea otters delivered to zoos range from $\$ 40,000$ to $\$ 50,000$, although in situ values would likely be lower because capture and preparation services are not required. However, the market for otters is very thin, since few permits for capture have been issued since the 1972 Marine Mammal Protection Act. A more relevant price may be the cost of relocating otters, which range from $\$ 1,500$ to 20,000 per otter, depending on numbers relocated. Brown's best estimate of unit costs for relocating sea otters was $\$ 11,500$ ( $\$ 12,800$ in 1993 dollars). By comparison, Exxon reported spending $\$ 90,000$ per released otter rescued in Prince William Sound.

2) Seals are generally more abundant than sea otters, and can be replaced for an estimated $\$ 700$ each. However, the market for seals is also extremely thin and this value is uncertain.

3) Eagles. A total of 200 to 500 eagles were estimated to have been killed or injured during the oil spill. Exxon reported spending $\$ 1.5$ million in 1989 to rehabilitate 15 eagles, or $\$ 100,000$ per eagle. Brown's best estimate of replacement cost was $\$ 22,000$ a piece.

4) Seabirds, shorebirds, and murres accounted for most of the animals killed in the oil spill. Because of their strong homing instincts, birds cannot be relocated, but must instead be bred. Unit costs were estimated to range from $\$ 274$ for murres to about $\$ 300$ for most other seabirds and shorebirds. 
It is difficult to critically assess the validity of methods used by Brown for determining unit values for animals affected by the Exxon Valdez oil spill. The largest source of error is that the market for most of the animals affected by the oil spill is extremely thin; limited demand and supply makes prices difficult to determine.

Exhibit 4-6:

ARI's estimate of wildlife damages due to Exxon Valdez oil spill (Based on Brown, 1992; Carson et al., 1992)

\begin{tabular}{|l|c|c|c|c||}
\hline \multicolumn{1}{|c|}{ Animal } & Deaths & $\begin{array}{c}\text { Replacement } \\
\text { Value }\end{array}$ & $\begin{array}{c}\text { Damage } \\
\text { Million } \\
\mathbf{( \$ 1 9 8 9 )}\end{array}$ & $\begin{array}{c}\text { Damage } \\
\text { Million } \\
\mathbf{( \$ 1 9 9 3 )}\end{array}$ \\
\hline \hline Murres & 112,500 & $\$ 274$ & $\$ 30.8$ & $\$ 34.4$ \\
\hline Other birds & 28,000 & $\$ 300$ & $\$ 8.4$ & $\$ 9.4$ \\
\hline Bald eagles & 100 & $\$ 22,000$ & $\$ 2.2$ & $\$ 2.5$ \\
\hline Sea otters & 580 & $\$ 11,500$ & $\$ 6.7$ & $\$ 7.5$ \\
\hline Seals & 100 & $\$ 700$ & $\$ 0.1$ & $\$ 0.1$ \\
\hline Total & & $\$ 48.2$ & $\$ 53.9$ \\
\hline
\end{tabular}

\section{Non-Use Damages}

The final category of natural resources damages resulting from the Exxon Valdez oil spill to be analyzed is the potential injury to non-use values. Non-use values, defined in Section 2 of this report, encompass option, existence, bequest and other values which do not involve active user participation. Most economists recognize as valid, for example, that a person's option to visit an environmentally unspoiled area may have monetary value. Both the DOI regulations promulgated under CERCLA and the proposed NOAA regulations for OPA call for non-use values to be determined in the case of large, destructive spills such as the Exxon Valdez. At present, the only available methodology for measuring these values is contingent valuation $(\mathrm{CV})$, which attempts to create a hypothetical market for non-use natural resource services by providing respondents with the opportunity to buy or sell the services in question. 
The Attorney General of Alaska commissioned a contingent survey designed to measure damages to potential non-use values resulting from the Exxon Valdez oil spill (Carson et al., 1992). The developers of this study were researchers in CV and surveying methodology from UC, San Diego and Berkeley, Clark University, University of Maryland, and Resources for the Future. The survey was implemented by Westat, Inc., a survey research firm that was cited by the study as one of the most respected in the country.

The developers of the (CV survey sought to follow a conservative approach in framing the survey. The willingness to pay (WTP) format was selected for the CV study, rather than the less conservative willingness to accept (WTA) format, which is theoretically more correct for this oil spill situation. Demographic and other questions were included to develop valuation functions which could provide a check with theory and intuition.

The design of the CV survey began with development of the valuation scenario, based on information gained from six focus groups conducted in Washington state, Alaska, Maryland, Virginia, Missouri, and California. The draft survey was further refined through testing in a series of four pilot surveys in different parts of the country. Following finalization of the surveys, a random sample of 1,423 households from throughout the U.S. was drawn. Professional interviewers administered the face-to-face survey, which averaged 42 minutes in length, achieving a reportedly very high response rate of 75 percent.

During the survey, respondents were provided considerable information on the environmental impacts of the Exxon Valdez oil spill. Respondents were shown maps and photographs of the spill site, and representational photographs of a range of wildlife impacted by the spill (but no dead or injured animals), and of actual cleanup activities following the spill. Numbers of dead animals were presented, along with total populations and estimated recovery periods to allow comparison.

Following this lengthy introduction, which included collecting background and demographic information about the respondent, the issue of valuation was raised. The central question posed to respondents in the CV study was essentially: "How much would you be willing to pay in higher federal income taxes to prevent another oil spill in Prince William Sound 
comparable to that caused by the Exxon Valdez?" Respondents were told as a premise that if no action is taken over the next 10 years, scientists anticipate that such a spill would almost certainly reoccur.

Respondents were informed that their contribution, along with a matching fee paid by oil companies using the Valdez terminal, would pay for a realistic program that would prevent with certainty the injuries which would be cause by such a spill. This program would involve the escort of each tanker through Prince William Sound by two Coast Guard cutters, which would not only help preclude further grounding incidents, but would also carry spill containment equipment to ensure rapid response in the event of a spill. This program would continue for 10 years until the tanker fleet had converted to double-hull design. This plausible scenario was designed to ensure that respondents would have confidence that their contribution would be effective in achieving their intended goals.

A schedule of suggested per-household costs, selected based on the results of the pilot surveys, was shown to each respondent, rather than soliciting an open-ended answer. Three versions of these program cost answers were used, as shown in Exhibit 4-7 (versions A-15, A16, and A-17). The use of suggested tax categories tended to produce a tighter, more robust median, albeit at the risk of potential bias in affecting responses. For example, people tend to select answers close to the center of a suggested range, rather than the extremes.

Exhibit 4-7:

Program cost by version and question for the Exxon Valdez CV survey.

(Carson et al., 1992)

\begin{tabular}{|c|c|c|c|}
\hline Version & A-15 & $\mathbf{A - 1 6}$ & $\mathbf{\Lambda - 1 7}$ \\
\hline \hline A & $\$ 10$ & $\$ 30$ & $\$ 5$ \\
\hline B & $\$ 30$ & $\$ 60$ & $\$ 10$ \\
\hline C & $\$ 60$ & $\$ 120$ & $\$ 30$ \\
\hline D & $\$ 120$ & $\$ 250$ & $\$ 60$ \\
\hline
\end{tabular}


Complementing these quantitative answers, the CV survey also elicited qualitative responses from the survey, which provided several indications of the magnitude of passive use losses resulting from the Exxon Valdez oil spill. For example, over 90 percent of respondents said that they were aware of the oil spill, and over half agreed with a description of the spill as one of the largest environmental accidents caused by humans anywhere in the world.

Willingness-to-pay responses were analyzed using four methods of statistical distribution, including Weibull, exponential, log-normal, and log-logistic (Exhibit 4-8). The median household WTP for the spill prevention plan was chosen as the best indicator, because it was found to vary over a much narrower range than mean WTP. The median estimates of all four distributions are similar and their 95 percent confidence intervals overlap. All four estimates of the median are consistent with respect to the $\$ 30-\$ 60$ interval. The Weibull distribution is the most frequently used by statisticians for survival data and was chosen as the best single indicator of WTP.

Exhibit 4-8:

Statistical distributions of WTP for Exxon Valdez oil spill.

(Carson et al., 1992)

\begin{tabular}{||l|c|c|c|c||}
\hline Distribution & Median & $\begin{array}{c}95 \% \\
\text { Confidence } \\
\text { Interval }\end{array}$ & Mean & $\begin{array}{c}95 \% \\
\text { Confidence } \\
\text { Interval }\end{array}$ \\
\hline \hline Weibull & 30.91 & $26.85-35.59$ & 94.47 & $83.45-105.19$ \\
\hline Exponential & 46.29 & $43.07-49.75$ & 66.78 & $62.73-70.83$ \\
\hline Log-Normal & 27.32 & $23.67-31.52$ & 220.4 & $113.31-327.55$ \\
\hline Log-Logistic & 28.74 & $24.91-33.16$ & Infin. & \\
\hline
\end{tabular}

The final step of the $\mathrm{CV}$ study in quantifying the non-use natural resource damages caused by the Exxon Valdez oil spill was to determine the size of the population affected by the spill. The study assumed that the entire U.S. population suffered non-use damages from the spill, based primarily on the similarity in survey response throughout all regions of the country. Multiplying this by the number of U.S. households, adjusted for non-English speakers, yielded a non-use damage estimate of $\$ 2.8$ billion (Exhibit $4-9$ ). 
Exhibit 4-9:

W'TP to prevent another oil spill in Prince William Sound.

(Carson et al., 1992)

\begin{tabular}{|c|c|c|c|c|c|}
\hline $\begin{array}{c}\text { Households } \\
\text { Contacted }\end{array}$ & $\begin{array}{c}\text { Households } \\
\text { Responding }\end{array}$ & $\begin{array}{c}\text { Median } \\
\text { WTP }\end{array}$ & $\begin{array}{c}\text { U.S. } \\
\text { Households } \\
\text { (English- } \\
\text { Speaking) }\end{array}$ & $\begin{array}{c}\text { Non-Use } \\
\text { Value } \\
\mathbf{( \$ 1 9 9 1} \\
\text { million) }\end{array}$ & $\begin{array}{c}\text { Non-Use } \\
\text { Value } \\
\mathbf{( \$ 1 9 9 3} \\
\text { million) }\end{array}$ \\
\hline \hline 1,423 & 1,043 & 31.00 & $90,838,000$ & 2,800 & 3,000 \\
\hline
\end{tabular}

\section{Critical Analysis}

The Carson et al. survey is widely considered by economists to be one of the most sophisticated contingent valuation studies performed to date for assessing non-use natural resource damages. The survey apparently did not seriously violate any of the suggested guidelines set forth in the subsequent NOAA CV Panel report (NOAA, 1993). The follow-up analysis showed that the exclusion of protest responses (anti-tax or industry) or of unrealistically high WTP values ( $>1 \%$ of income) affected median WTP by only $10 \%$ or less. WTP was found to increase in a logical manner with income, self-identification as a strong environmentalist, and other demographic and ancillary data collected by the survey.

However, ARI has identified two possible sources of error in the methodology of the CV survey, which may have led to upward bias in WTP.

1) Respondents' WTP was solicited based on a rigid schedule of defined choices (Exhibit 4-7). While this helped the surveyors to achieve an admirably robust statistical median, it also may have biased the responses. For example, respondents may have avoided selecting the lowest proposed WTP values or indicating even lower values out of concern about appearing uncaring about the environment. A counter argument could be made that the schedule similarly discouraged high WTP values, but the fact that respondents' answers clustered near the low end of the schedule makes downward bias much less likely than upward bias. 
2) No information was supplied regarding the average number of people per interviewed household. In calculating national WTP, the CV study made the implicit assumption that the average size of the interviewed household was identical to national household size (about 2.7 persons per household). In practice, households where one member is home during daytime hours to respond to the survey are likely to be larger than average. Deviations from this national average would directly affect estimated non-use values. 


\subsubsection{S.S. Glacier Bay Oil Spill}

\section{Introduction}

On July 2, 1987, an oil spill occurred in Cook Inlet, Alaska, when the 81,000-dwt S.S. Glacier Bay hit an uncharted submerged rock (Exhibit 4-10). The tanker was carrying 380,000 bbls of North Slope crude oil from the Alyeska Pipeline Service Co.'s Valdez terminal to the Kenai Pipeline Co.'s facilities at Nikishka to offload oil. The total volume of oil spilled has not been precisely determined; estimates range from 158,760 to 207,564 gallons, out of a total load of nearly 16 million gallons, creating the largest oil spill in the state of Alaska prior to the Exxon Valdez spill.

Natural resource damages due to the Glacier Bay oil spill were considerable, primarily because the spill coincided with the month-long peak of the prolific salmon run on the Kenai River. The total ex-vessel value of commercially harvested Cook Inlet salmon averages approximately $\$ 95$ million during this 4-week period, and the 1987 oil spill resulted in the loss of about half of the catch in that year, as well as significant damage to vessels and nets.

Three years following the Glacier Bay oil spill, the Minerals Management Service (MMS) commissioned an economic assessment by Northern Economics, a consulting firm based in Anchorage (Burden et al., 1990). Because of the substantial time lapse, Northern Economics reported difficulty in obtaining certain data, particularly after the subsequent Exxon Valdez oil spill placed extraordinary demands on agency and industry staff. Additional studies on natural resources damages were conducted by NOAA and the Alaska Attorney General's office, but are not yet available because of ongoing litigation.

The MMS study of the Glacier Bay spill was selected for analysis because it provides particularly valuable information on the public costs of oil cleanup and on the distributional effects of the oil spill on commercial fishing, recreation, subsistence, government entities, and property values. Cleanup costs were determined in considerable detail based on accounts of manpower, vessels, vehicles, equipment, materials, and expenditures involved in the spill response, cleanup, and compensation. 


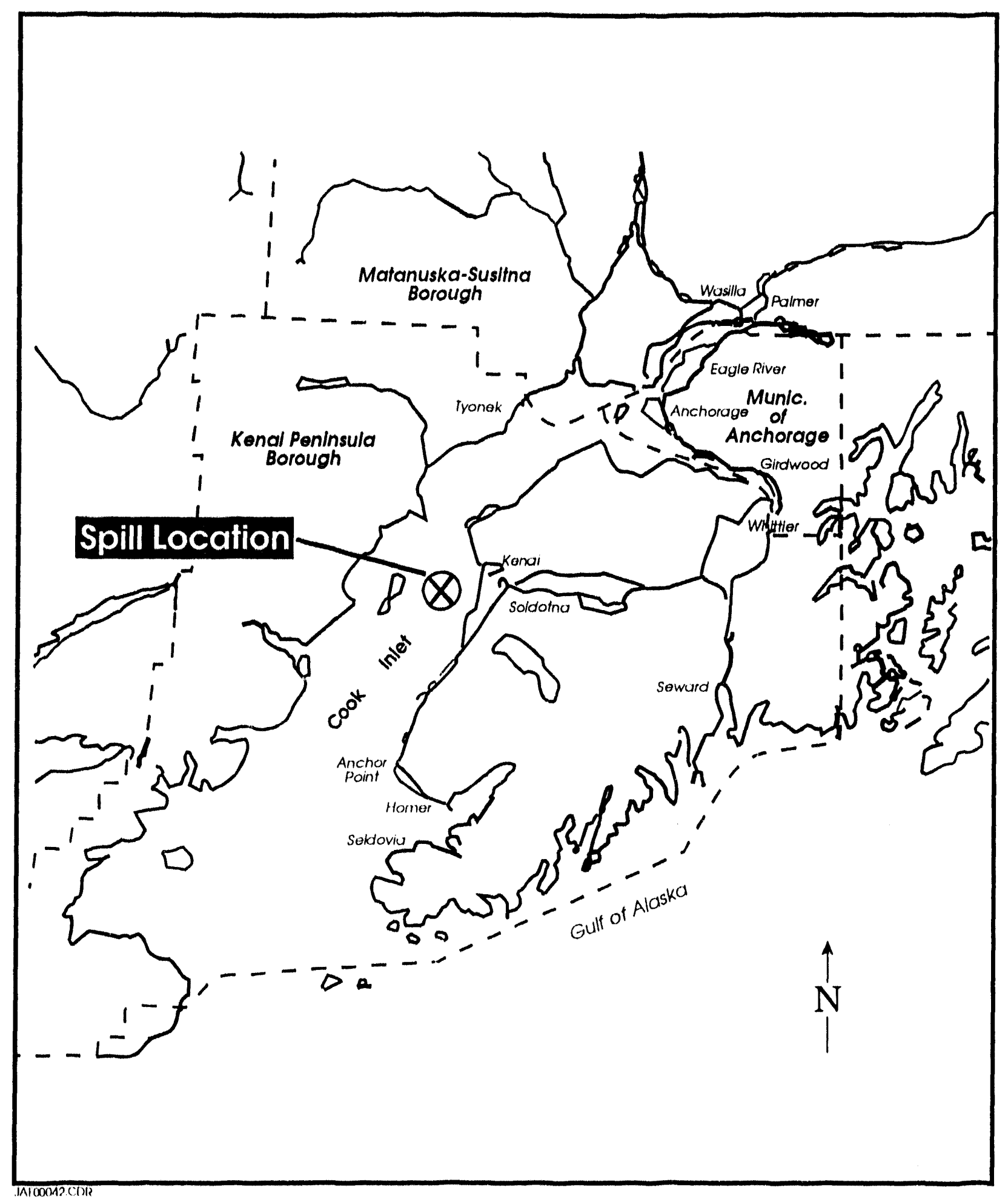

Exhibit 4-10:

S.S. Glacier Bay spill study area. 
Another important aspect of the MMS study is that it quantifies oil spill cleanup and damage costs in the Cook Inlet, which since 1957 has been an important offshore petroleum producing province. Consequently, the study also may provide an indication of costs for potential spills from offshore production platforms, for which recent (post-1979) data are not available. However, Cook Inlet cleanup costs are likely to be higher than those in the Lower 48 states due to limited infrastructure and seasonal factors such as winter icing (though ice was not a factor in the Glacier Bay spill).

As with all cost information in this report, costs from the MMS study were adjusted to 1993 dollars using the U.S. Department of Commerce's GNP implicit price deflator (Exhibit 11). All costs developed in the MMS study were multiplied by 1.211 to yield costs corrected to January 1, 1993 dollars. Cost information is summarized in Exhibit 4-11, disaggregated by cleanup and damages categories.

\section{Response and Cleanup Costs}

The MMS study documented direct response and cleanup costs incurred by several groups, including the owners of the S.S. Glacier Bay, the U.S. Coast Guard, the U.S. Departments of Commerce and Interior, and state and local governmental agencies. Costs recorded were those associated with the spill event and response actions taken; they do not include costs associated with litigation. The period of costs covered for the cleanup was July 2, the day of the spill, to August 15, 1987, when cleanup activities ceased. Ongoing litigation caused several participants to withhold information on cleanup costs; the MMS study estimated these costs based on available data.

Based on analysis of a detailed chronology reconstructing the actions of industry and government agencies during the response to the Glacier Bay oil spill, the MMS study determined that significant inefficiencies resulted in unreasonably high cleanup costs (which is likely to occur in any large, poorly planned cleanup effort). For example, the large number of parties involved in the oil spill led to lack of initial coordination and ineffective response measures. Efficient cleanup was also hampered by concerns over liability and the lack of a formal set of agreements governing duties of industry participants and response resources. Significant time 
was wasted determining that available equipment was not working and in arranging for procurement of additional equipment. As commonly is the case, future cleanup costs for an oil spill in the same region are expected to be considerable lower.

Cleanup costs for each affected firm or government agency are summarized in Exhibit 4-11 and discussed in detail in the following paragraphs.

S.S. Glacier Bay owners incurred direct costs of $\$ 615,661$ in payment to subcontractors for cleanup services due to the oil spill. Subcontractor costs included ship rental, purchase of specialized cleanup equipment and chemicals, and labor. Total costs amounted to $\$ 745,565$ in adjusted 1993 dollars (Exhibit 4-11).

The U.S. Coast Guard, as the Federal On-Scene Coordinator (FOSC), incurred expenses for response and cleanup activities during the spill. Although these amounts remain the subject of litigation and the actual amount which will be paid is uncertain, the MMS study reported the Coast Guard claimed total response and cleanup related costs of $\$ 1,722,860$. The largest share of these costs, $\$ 1,012,647$ or $59 \%$ of total costs, was incurred to hire spill response subcontractors. Coast Guard salaries, which amounted to only $\$ 46,363$ or $2.7 \%$ of total outlays during the cleanup period, were included for the purpose of the present study, since time spent on the oil spill is lost to other duties. Coast Guard total cleanup cost amounted to $\$ 2,086,384$ in 1993 dollars (Exhibit 4-11).

U.S. Departments of Commerce and Interior have submitted claims of $\$ 399,000$ for costs incurred during the cleanup. These costs included NOAA's help in environmental assessment and the establishment of a consistent monitoring program. Salary costs for full-time personnel were not separately reported. Adjusted to 1993 dollars, these costs totaled $\$ 483,189$ (Exhibit 4-11).

Alaska Department of Environmental Conservation was the primary state agency providing direction on spill response. Activities included monitoring the spill, providing technical assistance to the spiller and the Coast Guard during cleanup, documenting spill impacts, approving the efficacy of cleanup operations, and inspecting commercially harvested 
salmon for possible oil contamination. Total cleanup-related costs amounted to $\$ 226,595$, of which salaries again was the largest single component (68\% of total). Total agency cleanup costs adjusted to 1993 dollars was $\$ 274,407$ (Exhibit 4-11).

Alaska Department of Fish and Game assisted in assessing the size, extent, and impacts of the spill to commercial and recreational fisheries in the area, and assessed impacts of the spill on fish and game resources and habitats. These costs totaled $\$ 62,770$ for the cleanup period. The largest single cost component was for salaries, accounting for $46 \%$ of total costs. The next largest expense (37\%) went to conducting a special test fishery, to determine oil contamination of fish and the need to adjust openings and closures for area fisheries. Total agency costs adjusted to 1993 dollars was $\$ 76,014$ (Exhibit 4-11).

Alaska Attorney General's Office was responsible for aggregating state costs associated with the oil spill and pursuing litigation to recover those costs. Due to ongoing litigation, these costs were not available for this study.

Alaska Department of Natural Resources was involved in beach monitoring of oil spill impacts, but did not report any incurred costs.

Cleanup Contractors. In response to rapidly changing events surrounding the oil spill, contractors reported receiving verbal directives above and beyond contracted tasks, which sometimes were not reimbursed. For some contractors, non-reimbursed expenses ranged from 20 to 30 percent of total invoice amounts submitted. However, these additional costs were not considered in this analysis.

\section{Damages}

Direct use damages due to the Glacier Bay oil spill were determined based on interviews with randomly selected target groups for each potentially injured industry. The commercial and recreational fishing and fish processing industries were the only groups determined to have suffered damages. However, these damages were quite large, because the oil spill coincided 
Exhibit 4-11:

Cleanup costs and natural resource damages for the S.S. Glacier Bay oil spill (Burden et al., 1990)

\begin{tabular}{|c|c|c|c|c|c|c|c|c|c|}
\hline \multirow[b]{2}{*}{ Impacted Group } & \multicolumn{3}{|c|}{ Direct Cleanup Costs } & \multicolumn{3}{|c|}{ Direct Use Damages } & \multirow{2}{*}{$\begin{array}{l}\text { Non-Use } \\
\text { Damages* } \\
1993 \text { \$/gal }\end{array}$} & \multicolumn{2}{|c|}{ Total* } \\
\hline & $1987 \$$ & $1993 \$$ & 1993 \$/gal & $1987 \$$ & 1993 S & 1993 \$/gal & & 1993 S & 1993 S/gal \\
\hline Government Sector & & & & & & & & & \\
\hline U.S. Coast Guard & $1,722,860$ & $2,086,384$ & 11.39 & -- & -- & - & & $2,086,384$ & 11.39 \\
\hline Commerce/NOAA & 399,000 & 483,189 & 2.64 & - & - & -- & & 483,189 & 2.64 \\
\hline $\begin{array}{l}\text { Alaska Dept. of } \\
\text { Environ. Conser. }\end{array}$ & 226,595 & 274,407 & 1.50 & - & - & -- & & 274,407 & 1.50 \\
\hline $\begin{array}{l}\text { AK Dept. of Fish \& } \\
\text { Game }\end{array}$ & 62,770 & 76,014 & 0.42 & -- & - & - & & 76,014 & 0.42 \\
\hline AK Attorney General & - & - & -- & 11,197 & 13,560 & 0.07 & & 13,560 & 0.07 \\
\hline $\begin{array}{l}\text { TOTAL GOV'T } \\
\text { SECTOR }\end{array}$ & $2,411,225$ & $2,919,994$ & 15.94 & 11,197 & 13,560 & 0.07 & & $2,931,191$ & 16.00 \\
\hline $\begin{array}{l}\frac{\text { Industry }}{\text { S.S. Glacier Bay }} \\
\text { Drift Net Fisheries } \\
\text { Set Net Fisheries } \\
\text { Fish Processing } \\
\text { Sport Fishing } \\
\text { Subsistence Fishing }\end{array}$ & $\begin{array}{c}615,661 \\
-- \\
-- \\
-- \\
-- \\
--\end{array}$ & $\begin{array}{c}745,565 \\
-- \\
- \\
-- \\
- \\
-\end{array}$ & $\begin{array}{c}4.07 \\
- \\
- \\
- \\
- \\
-\end{array}$ & $\begin{array}{c}89,550 \\
41,600,000 \\
12,100,000 \\
1,123,230 \\
-- \\
--\end{array}$ & $\begin{array}{c}108,445 \\
50,400,000 \\
14,700,000 \\
1,360,000\end{array}$ & $\begin{array}{c}0.59 \\
275.17 \\
80.26 \\
7.43\end{array}$ & & $\begin{array}{c}854,010 \\
50,400,000 \\
14,700,000 \\
1,360,000\end{array}$ & $\begin{array}{c}4.66 \\
275.17 \\
80.26 \\
7.43\end{array}$ \\
\hline $\begin{array}{l}\text { TOTAL INDUSTRY } \\
\text { SECTOR }\end{array}$ & 615,661 & 745,565 & 4.07 & $54,912,780$ & $66,568,445$ & 363.44 & 5.46 & $68,314,075$ & 372.97 \\
\hline TOTAL (Average) & $3,026,886$ & $3,665,559$ & 20.01 & $54,923,977$ & $66,582,005$ & 363.51 & 5.46 & $71,245,266$ & 388.97 \\
\hline
\end{tabular}

* ARI Estimate 
with the peak of the prolific salmon run up the Kenai River. Recreational and subsistence fisheries were not adversely affected by the spill, according to interviews conducted with recreational fishing representatives and with village council presidents for the three subsistence fisheries in Cook Inlet (Port Graham, English Bay, and Tyonek). Damages incurred by bird watching and other non-extractive recreation was not investigated by the MMS study, nor were existence and other non-use values. The following is a summary of damages by industry and government agency caused by the Glacier Bay oil spill. These costs are summarized in Exhibit 4-11.

S.S. Glacier Bay owners reported costs totaling $\$ 22,650$ to repair damage to the ship due to the grounding which caused the oil spill. Oil spilled during the incident was estimated to be 3,780 to 4,942 bbls, for an average estimate of 4,341 bbls. Assuming an average delivered price of $\$ 15.41$ per bbl at Nikiski termiıal, cargo losses totaled $\$ 66,900$. Therefore, losses due to the oil spill totaled $\$ 89,550$, or $\$ 108,445$ adjusted to 1993 dollars (Exhibit $4-11$ ). Additional potential losses may have included the opportunity cost of use of the ship during repairs, but this factor was not considered in the MMS study.

Alaska Attorney General's Office estimated the value of fish tax revenue foregone due to discard of contaminated fish, and fish not caught due to closures. These lost tax revenues totaled $\$ 11,197$, or $\$ 13,560$ in 1993 dollars (Exhibit 4-11).

Drift net fishermen suffered one of the largest damages due to the Glacier Bay spill. Based on interviews with 26 randomly selected fishermen, the MMS study determined that fish losses, gear damage, and oiled vessels averaged $\$ 69,318$ per fisherman. Total industry losses were calculated to be about $\$ 41.6$ million, which adjusted to 1993 dollars totals approximately $\$ 50.4$ million (Exhibit 4-11). Fish unit prices also dropped from $\$ 1.73$ per pound just prior to the spill to $\$ 1.40$ during the oil spill period, but appeared to be due primarily to a record catch (in spite of the spill) rather than reduced demand due to the oil spill.

Set net fishermen accounted for the second largest losses from the oil spill. Interviews with 58 randomly selected fishermen determined that average damages for lost fish revenues, 
gear damage, and oiled vessels amounted to $\$ 33,050$ per fïsherman. Industry losses totaled $\$ 12.1$ million, or $\$ 14.7$ million in adjusted 1993 dollars (Exhibit 4-11).

Fish processors estimated the total value of the $261,000 \mathrm{lbs}$ of documented salmon that had to be discarded due to contamination to be $\$ 373,230$. However, the actual loss reportedly was higher due to additional labor required to find, isolate and discard contaminated salmon, particularly since oil moved unpredictably throughout the drift fishing areas. This additional handling cost was estimated to be $\$ 0.20$ to $\$ 0.30 / \mathrm{lb}$, an additional cost of about $\$ 750,000$, for a total loss of approximately $\$ 1,123,000$. Adjusted to 1993 dollars, losses totaled $\$ 1.36$ million (Exhibit 4-11).

Recreation and sport fishing were not adversely affected by the Glacier Bay oil spill. Cook Inlet waters account for a large proportion (56\%) of the total 1,212,704 angler days of sport fishing days in Alaska. However, recreational fishing in Cook Inlet takes place primarily in fresh water tributaries and is much more dispersed throughout the year; consequently damage due to the oil spill was limited or did not occur. With few exceptions, sport fishing groups indicated they did not experience negative impacts from the oil spill, because they operate primarily in fresh waters upstream of the oil spill location. Recreational fishing may even have inadvertently benefitted from the spill, in that restriction of fishing downstream led to increased runs in the Kenai River (Burden et al., 1990, p. 79).

Subsistence and personal use fisheries, including three Conk Inlet villages, were contacted but reported no impacts due to the oil spill. All three villages are located outside the geographic range of the spill.

\section{Critical Analysis}

The MMS study of the economic impacts of the Glacier Bay oil spill provided valuable information on cleanup and direct use natural resource damages in a commercially sensitive area. Particularly instructive is the detail describing cleanup costs by group, as well as the potential for excess costs due to poor coordination among agencies and the private sector. 
However, there were several weaknesses with the MMS report which should be considered:

1) The MMS study did not value non-use damages, such as existence and option values, which are expressly permitted under CERCLA and OPA 90. The city of Anchorage, with a metropolitan area population of approximately 200,000, lies less than 100 miles from the spill. The population whose non-use values were adversely affected by the Glacier Bay spill may be expected to include the Anchorage metropolitan area. Modest WTP values for preventing a comparable oil spill, perhaps $\$ 2$ per person (an order of magnitude less than that determined for the Exxon Valdez spill) would be expected to generate on the order of $\$ 2$ million in non-use damages relating to this spill. If the affected population included sports fishermen and recreational users in the Lower 48, WTP values could be significantly higher.

2) Due to litigation, information was incomplete or not available for a number of potentially affected groups. These included government agencies such as the Fish and Wildlife Service and the Alaska Attorney General's office. A more serious potential flaw in the study methodology is that damage estimates for commercial fishing were based on interviews with a small subset of fisherman, yielding cost estimates that varied ten-fold. A more accurate estimate of lost fishing damages might be obtained by valuing the reduced catch. 


\subsubsection{Amazon Venture (Savannah River, Georgia and South Carolina)}

Between December 4 and 8, 1986, the tanker Amazon Venture spilled approximately 500,000 gals of No. 6 fuel oil into the Savannah River between Georgia and South Carolina (Michel, 1989). The spill affected natural resources managed by the states of South Carolina and Georgia, and three federal agencies: the U.S. Fish and Wildlife Service (FWS), the National Park Service, and the National Oceanic and Atmospheric Administration (NOAA). These agencies joined together as co-trustees in conducting cleanup and natural resource damage assessment. At the time of the spill, only the CERCLA Type B damage assessment rule was in effect, however, the trustees opted to conduct a more limited pre-assessment damage study because of the anticipated expense of a full Type B assessment.

The Amazon Venture oil spill caused heavy to medium contamination of about 650 acres of marshland along the banks of the Savannah River, while an additional 690 acres were lightly oiled (Exhibit 4-12). The trustees pursued two methods for estimating natural resource damages to wetlands caused by the spill. First, for the wetlands that were moderately damaged and expected to recover, the lost direct-use services provided by the injured resources were quantified. Second, for the wetlands that were essentially permanently damaged, the replacement cost of constructing a substitute marsh was estimated. Additional damages were quantified for injuries to fish and wildlife, using physical and toxicological models to estimate the numbers of organisms affected. Finally, assessment costs and other costs due to the oil spill were quantified. Potential non-use damages due to the spill were not addressed.

A damage assessment published for the Amazon Venture spill documented a total of $\$ 2.37$ million in cleanup costs and natural resource damages due to the spill (Michel, 1989). In comparison, the owners of the Amazon Venture settled out of court for a reported $\$ 1.2$ million. This settlement, amounting to only $\$ 3.00$ per gallon in 1993 dollars, was the lowest unit damage value for any of the oil spills assessed in this report. 


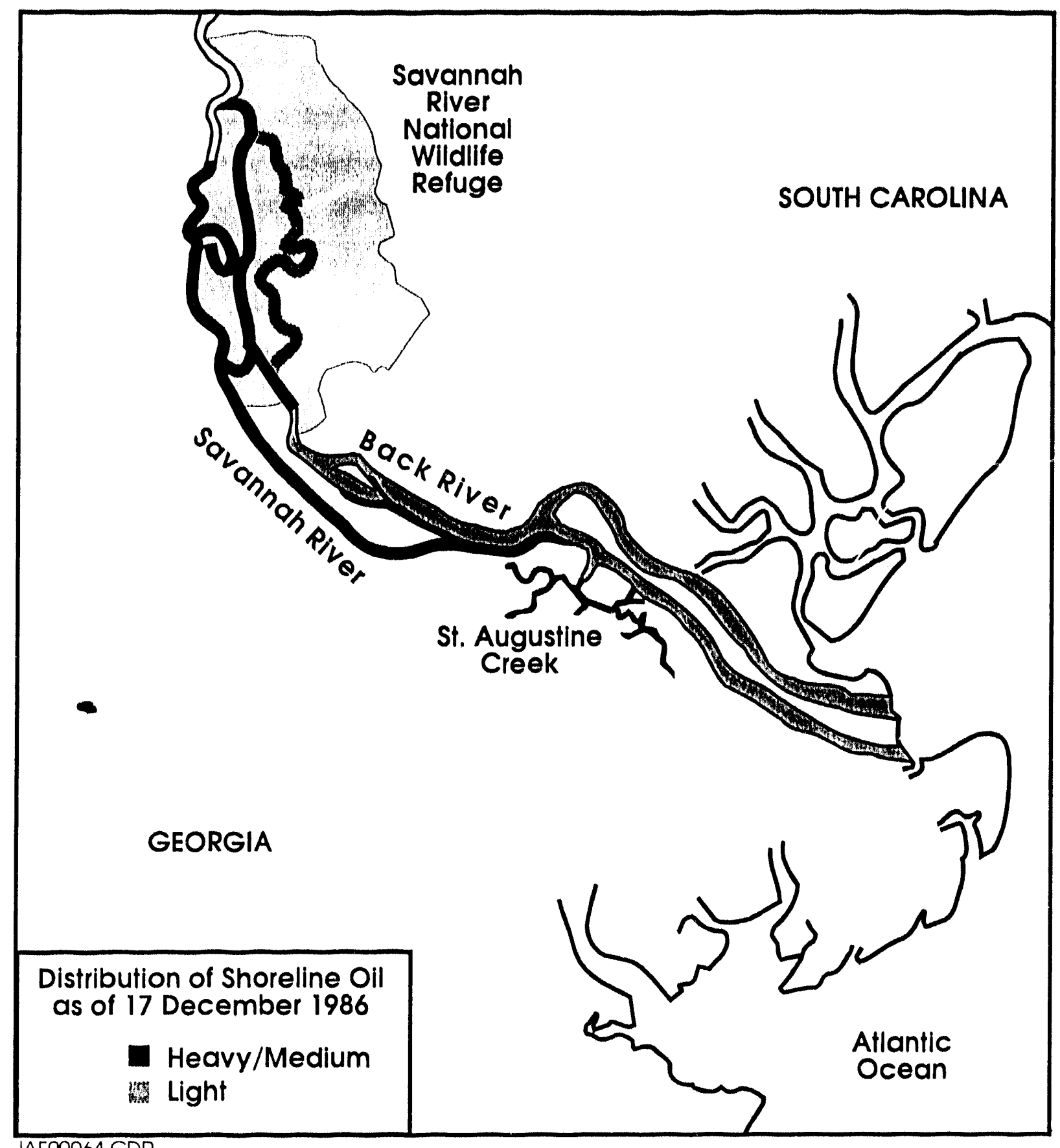

JAFOOO64.CDR

Exhibit 4-12:

Map of impact area from the Amazon Venture oil spill.

Response and Cleanup Costs

A total of 150,000 gallons out of the estimated 500,000 gallons of oil spilled was eventually recovered during cleanup operations. No published estimates of response and cleanup costs are available. However, based on the duration of the cleanup operation (one month), and 
conversations with Georgia and South Carolina state environmental agencies, which indicated a daily rate of approximately $\$ 35,000$, ARI estimates that a total of $\$ 1.1$ million was spent on response and cleanup. At $\$ 2.75$ per gallon spilled (1993\$), this cleanup charge was one of the lowest unit costs of all oil spills analyzed in this study, probably because of low dispersal rates due to the highly viscous No. 6 fuel oil spilled and the slowly moving portion of the river where the spilled occurred.

\section{Assessment Costs}

Each of the natural resource co-trustees involved in the Amazon Venture oil spill reportedly kept detailed records of costs incurred in assessing damages (Michel, 1989). Because a limited Type A damage assessment approach was taken, assessment costs totaled only $\$ 104,000$. Assessment unit costs amounted to only $\$ 0.26 / \mathrm{bbl}$ (1993\$), which was far below costs for assessing the other spills analyzed in this report, which ranged from

\section{Natural Resource Damage Costs}

Commercial and recreational fishing and hunting. Damages were calculated for sitespecific losses of use during the Amazon Venture spill, when areas were closed or restricted to use for a period of 20 days. Recreational losses for bird watching and other non-consumptive uses were not estimated because of lack of data. Separate loss-of-use damages due to the oil spill were estimated for waterfowl hunting, recreational sport fishing, commercial clam fishing, creational oyster fishing, and commercial shrimp fishing. Total loss-of-use damages were estimated to be $\$ 275.368$ to $\$ 414,024$, for a central estimate of $\$ 344,696$ (Exhibit 4-13).

Wetlands services. Wetlands are recognized as providing important functions essential to the long-term functioning of the ecological system. These benefits include nurseries for fish, flood hazard reduction, erosion control, and many other functions. The moderate to heavily contaminated wetlands were estimated to recover over two years, while published per-acre values ranging from $\$ 3,000 /$ acre to $\$ 15,059$ was used. These assumptions led to computed estimates of $\$ 246,750$ to $\$ 993,960$ (central estimate $\$ 620,355$ ) for total damages to wetlands services due to the Amazon Venture oil spill (Exhibit 4-13). 
Exhibit 4-13:

Natural resource damages for the Amazon Venture oil spill (Michel, 1989)

\begin{tabular}{|c|c|c|c|c|c|c|c|c|}
\hline & \multirow[b]{2}{*}{$\begin{array}{l}\text { Cleanup } \\
\text { Costs* }\end{array}$} & \multirow[b]{2}{*}{$\begin{array}{l}\text { Capital } \\
\text { Losses* }\end{array}$} & \multirow{2}{*}{$\begin{array}{c}\text { NRDA } \\
\text { Assessment } \\
\text { Costs* }\end{array}$} & \multirow{2}{*}{$\begin{array}{l}\text { Lost-Use } \\
\text { Damages }\end{array}$} & \multicolumn{2}{|c|}{ Non-use Damages } & \multirow[b]{2}{*}{ Total* } & \multirow[b]{2}{*}{$\begin{array}{c}\text { Actual } \\
\text { Settlement }\end{array}$} \\
\hline & & & & & $\begin{array}{l}\text { Wetlands } \\
\text { Services }\end{array}$ & $\begin{array}{l}\text { Fishery/Wildifife } \\
\text { Type A Model }\end{array}$ & & \\
\hline TOTAL (\$) & $\begin{array}{l}1.1 \\
\text { million }\end{array}$ & 140,000 & 104,000 & 344,696 & 620,355 & 65,318 & $\begin{array}{l}2.37 \\
\text { million }\end{array}$ & $\begin{array}{c}1.2 \\
\text { million }\end{array}$ \\
\hline $\begin{array}{l}\text { PER GALLON } \\
1991 \text { (\$/gal) }\end{array}$ & 2.20 & 0.28 & 0.21 & 0.69 & 1.24 & 0.13 & 4.75 & 2.40 \\
\hline 1993 \$/gal & 2.75 & 0.35 & 0.26 & 0.86 & 1.55 & 0.16 & 5.93 & 3.00 \\
\hline
\end{tabular}

* ARI Estimates 
Fishery and wildlife losses. Damages to fish and wildlife were assessed using a Draft Type A natural resource damage assessment computer model, developed by the U.S. Fish and Wildlife Service (described in Section 3.3 of this report). This model measured impacts due to the lethal effects of oil on larvae and adult fish and waterfowl, and the indirect and long-term effects involving eventual losses throughout the food chain. Although the CERCLA Type A damage assessment rule was not yet effective on the date of the spill, a draft computer model was used to carry out simplified assessments of damages to coastal and marine natural resources. Total losses quantified by the model amounted to $\$ 65,318$ (Exhibit 4-13).

\section{Critical Analysis}

The unit cleanup and damage costs documented in the Amazon Venture oil spill study are far less than those determined for the more-publicized Exxon Valdez and Glacier Bay tanker spills. Total assessed costs amounted to just $\$ 5.93$ per gallon spilled (1993\$), compared with $\$ 390$ and $\$ 556$ per gallon for the Glacier Bay and Exxon Valdez spills, respectively. However, the actual settlement for the Amazon Venture spill amounted to $\$ 3.00$ per gallon, which indicates that natural resource damage estimates were considered credible by all involved parties. Damages may have been limited by the winter weather conditions, which probably mitigated wildlife injuries, and the highly viscous nature of No. 6 fuel oil, which slowed the spread of the oil and kept cleanup costs relatively low.

The Michel (1989) study did not consider non-use natural resource damages, such as existence and option value. However, there is no reason to believe that the Amazon Venture spill was of national importance comparable to the Exxon Valdez spill, and it is likely that contingent valuation would have determined only limited non-use damages. 


\subsubsection{Mercer Statistical Data Base of Tanker Spill Costs}

Mercer Management (formerly Temple, Barker \& Sloan) has developed a proprictary data base of oil spill cleanup and third-party damages resulting from recent tanker and barge spills (Mercer Management, 1992). The data base contains cost data on spills of more than 100,000 gallons that occurred between 1980 and 1991, based on information obtained through interviews with P\&I clubs (insurance providers). The data base is of limited use for the purposes of this report, in that only actual or estimated costs are presented; no analysis was performed on what precisely the costs represent or on what basis damages were developed. In addition, very few of the spills contained in the data base fall under the Oil Pollution Act of 1990 and it is likely that none were settled using the NRDA framework set forth in the Act. Nevertheless, the Mercer data base provides a useful source of raw data on cleanup and natural resource damages for several spills.

The Mercer data base contains basic information on natural resource damages for two tanker spills: the Nestucca and the World Prodigy. These values are based on actual settlements, which for most spills have tended to be considerably smaller than theoretical estimated damages. Settlements are summarized in Exhibit 4-14.

Exhibit 4-14:

Actual settlements of natural resource damages for two tanker spills (Mercer Management, 1992).

\begin{tabular}{|c|c|c|}
\hline Tanker & $\begin{array}{c}\text { Spill Size } \\
\text { (million gal) }\end{array}$ & $\begin{array}{c}\text { Actual NRD } \\
\mathbf{( 1 9 9 3 ~ \$ / g a l ) ~}\end{array}$ \\
\hline Nestucca & 4.3 & $\$ 18.60$ \\
\hline World Prodigy & 1.2 & $\$ 4.15$ \\
\hline
\end{tabular}




\subsection{Pipeline Spills}

\section{Overview}

In contrast to the iitiinerous publicly available natural resource damage assessments conducted on tanker oil spills, much less information is available on oil spill costs from pipelines and refineries. The only publicly available natural resource damage assessment for this category is a study conducted on Exxon's Arthur Kill pipeline spill in New Jersey. This study was augmented witli useful but less detailed cost information from Texaco's Anacortes refinery spill in Washington state, which led to the first settlement with natural resource trustees under the Oil Pollution Act of 1990. The Exxon and Texaco spills provide a comparison of two widely different environmental and regulatory settings: Whereas the Arthur Kill oil spill occurred in an intensively industrialized setting, with only minor recreational damages, the Texaco spill occurred in an environmentally more sensitive setting. Despite the paucity of data, these two case studies, which occurred in different settings and were prosecuted under different laws, provide an indication of the range in cleanup costs and natural resource damages due to pipeline and refinery spills under OPA 90.

Response and cleanup costs for the two pipeline/refinery case studies were relatively high, at approximately $\$ 30$ to $\$ 40$ per gallon in 1993 dollars, but still considerably lower than for most tanker spills. Damages to natural resources were more varied, ranging from $\$ 4$ to $\$ 40$ per gallon, with non-use values accounting for the largest and least well-defined component. These significant costs reflect the often sensitive environmental location of pipelines and refineries. Oil spills in biologically rich, shallow coastal waters or wetlands, where dilution and physical degradation due to wave action is slow, tend to cause considerable damage to natural resources. In contrast, production platform and most tanker oil spills frequently occur in the open marine environment, where rapid dissipation of the spill due to dilution and wave action usually leads to less serious damages.

Civil penalties relating to pipeline and refinery spills, based on discussirns with participants of the Texaco and Exxon oil spill damage assessments, tend to require substantial costs for pollution monitoring and prevention equipment and training. For example, prevention 
costs following Exxon's Arthur Kill pipeline oil spill amounted to $\$ 44.09$ per gallon, while Texaco was required to invest $\$ 3.81$ per gallon in prevention equipment and training due to its Anacortes refinery spill. Prevention costs vary significantly depending on existing equipment and procedures. Specific prevention costs tend to be much smaller or non-existent in damage settlements for tanker or barge oil spills due to their mobility; efforts at tanker spill prevention have generally focused on redesign, for example, the expensive double hull design and spill contingency plans required under OPA.

\subsubsection{Exxon Arthur Kill Oil Spill}

\section{Introduction}

On January 1, 1990, just seven months prior to the passage of OPA 90, an Exxon USA pipeline ruptured in the New York metropolitan area, spilling a total of 567,000 gallons of No. 2 fuel oil into a waterway between Staten Island and New Jersey. Although this spill was not covered by OPA 90, the previously enacted Clean Water Act (CWA) and Comprehensive Environmental Response, Compensation, and Liability Act of 1980 (CERCLA) permitted government agencies to claim damages for injuries to natural resources.

The estuary damaged by the Exxon pipeline spill was the Arthur Kill, a 15-mile-long by 1,000-ft-wide waterway which connects the Atlantic Ocean and New York Harbor (Exhibit 415). The Arthur Kill is used as an access channel by local recreational boaters and fisherman, and contains a variety of wetland habitats supporting an abundance of herons and other wildlife.

The Arthur Kill is an intensively developed industrial waterway. Directly adjacent to the largest landifll in the United States, the Arthur Kill is lined with a variety of chemical manufacturing and oil refining installations. Its water quality has been reported to be the poorest in the New York Harbor area. Consequently, the Arthur Kill spill provides an instructive case study of natural resource damages in an industrialized area, where pipeline and refinery spills are most likely to occur. The subsequent case study on Texaco's Washington State oil spill 


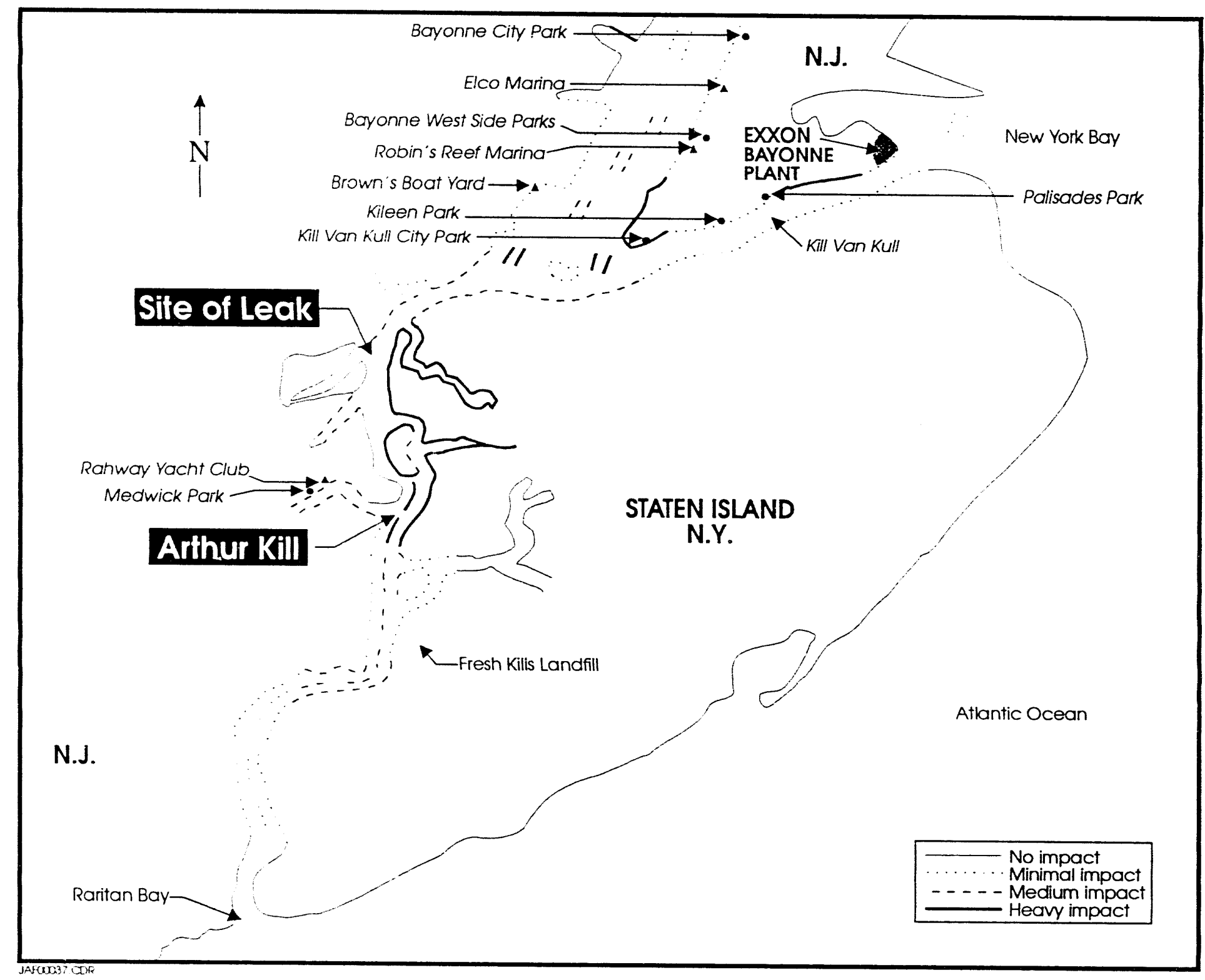

Exhibit 4-15:

Location of Exxon's Arthur Kill oil spill. 
(Section 4.3.2) provides a contrasting example of a refinery spill in an environmentally sensitive area.

As with all cost information in this report, costs related to the Arthur Kill oil spill were adjusted to 1993 levels using the U.S. Department of Commerce's GNP price inflator (Exhibit 1-1). Exxon's 1991 settlement costs were multiplied by 1.07 to yield costs corrected to January 1,1993 levels.

\section{Cleanup and Prevention Costs}

Exxon settled damages for the Arthur Kill spill in 1991 outside of court, paying a total of $\$ 58$ million in settlement costs. As part of this agreement, the NRDA performed by the government which provided the basis for the settlement is not publicly available. Only a NRDA performed on behalf of Exxon by Research Triangle Institute is available. The major components of the settlement, shown in Exhibit 4-16, included $\$ 18$ million for direct cleanup costs, $\$ 25$ million for the installation of advance monitoring and operational integrity assurance equipment and procedures to avoid future spills in the area, and $\$ 15$ million for restoration and remediation of natural resource damages (Exxon USA, 1991).

No additional information is available on Exxon's actual clean up and prevention costs. As to be expected with a fixed refinery/pipeline site, substantial prevention costs were included in the settlement, far more than levied in tanker spills cases. However, considerable information is available on natural resource damages resulting from the Arthur Kill oil spill, as discussed in the following section.

\section{Natural Resource Damages}

Exxon funded a separate NRDA of the Arthur Kill oil spill performed by Research Triangle Institute (RTI), which indicated a much lower extent of damages than that provided under its settlement with the government (Desvousges et al., 1993). RTI's economic study used 


\section{$\$ 62$ million Total Settlement Costs}

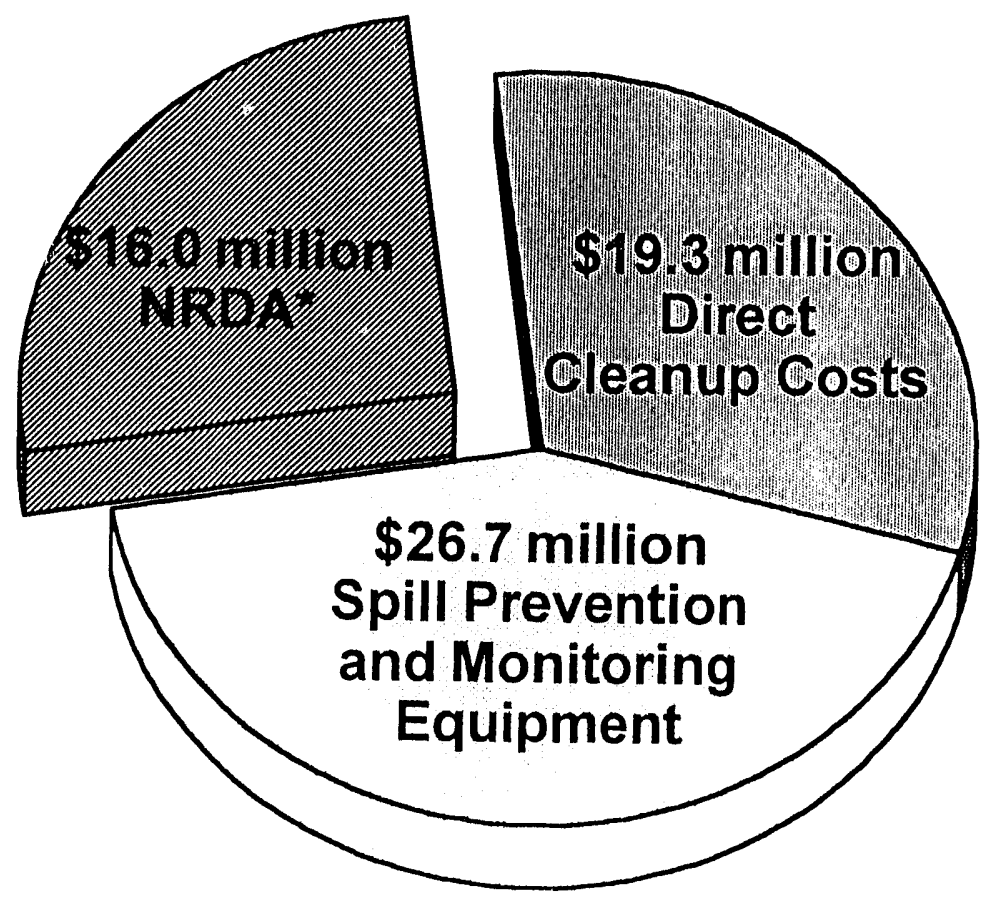

Exhibit 4-16:

Components of Exxon's settlement for the Arthur Kill oil spill, adjusted to 1993 dollars

(Source Exxon Co., 1991). *Not including damage assessment costs.

as a starting point the technical assessment of damage area and severity of the oil spill, which had been jointly conducted by Exxon and the local government authorities (B-Laing Associates, 1990). Two primary categories of potential damages were investigated: direct use (such as water-based recreation); and indirect non-use (such as existence values). RTI's study was limited in budget; to conserve resources it utilized the following "transfer" methodology, which relies on the monetary value for similar resource services from more extensive NRDA studies: 
Step 1 Obtain technical assessment of the change in water quality resulting from the oil spill.

Step 2 Collect basic socio-economic, recreation, and water quality information for the Arthur Kill area.

Step 3 Estimate per-household WTP to avoid losing access to the resource services, based on analogy to the previous NRDA study.

Step 4 Estimate the number of households who use the damaged resource to compute the aggregate value of damages.

RTI's damage estimates, broken down into use and non-use categories, are summarized in Exhibit 4-17. Damages to specific resources are discussed below.

\section{Recreation (Use) Damages}

Because the Arthur Kill is highly industrialized, no fishing or other commercial activity and very limited recreational activity takes place in the Kill itself. However, the Arthur Kill is an important access waterway to reach surrounding areas where recreational opportunities are more abundant. In addition, bird watching and picnicking take place along the shore of Arthur Kill, although these activities were very restricted during the winter timing of the spill. Boating and bird watching were the only direct uses of Arthur Kill which RTI identified as potentially impacted by the Exxon oil spill.

Boating. RTI contacted the operators of four marinas within one mile of Arthur Kill which provide services for local boaters. RTI asked these operators, who were presumed to be familiar with their customers' recreational activities in the area, for activity data for peak and off-peak periods. Boating activity during the winter period of the spill was at a minimum level.

The possibility that non-local boaters may have wished to use the Arthur Kill for access was not investigated. The following were the primary assumptions for RTI's computation of boating recreation damages: 


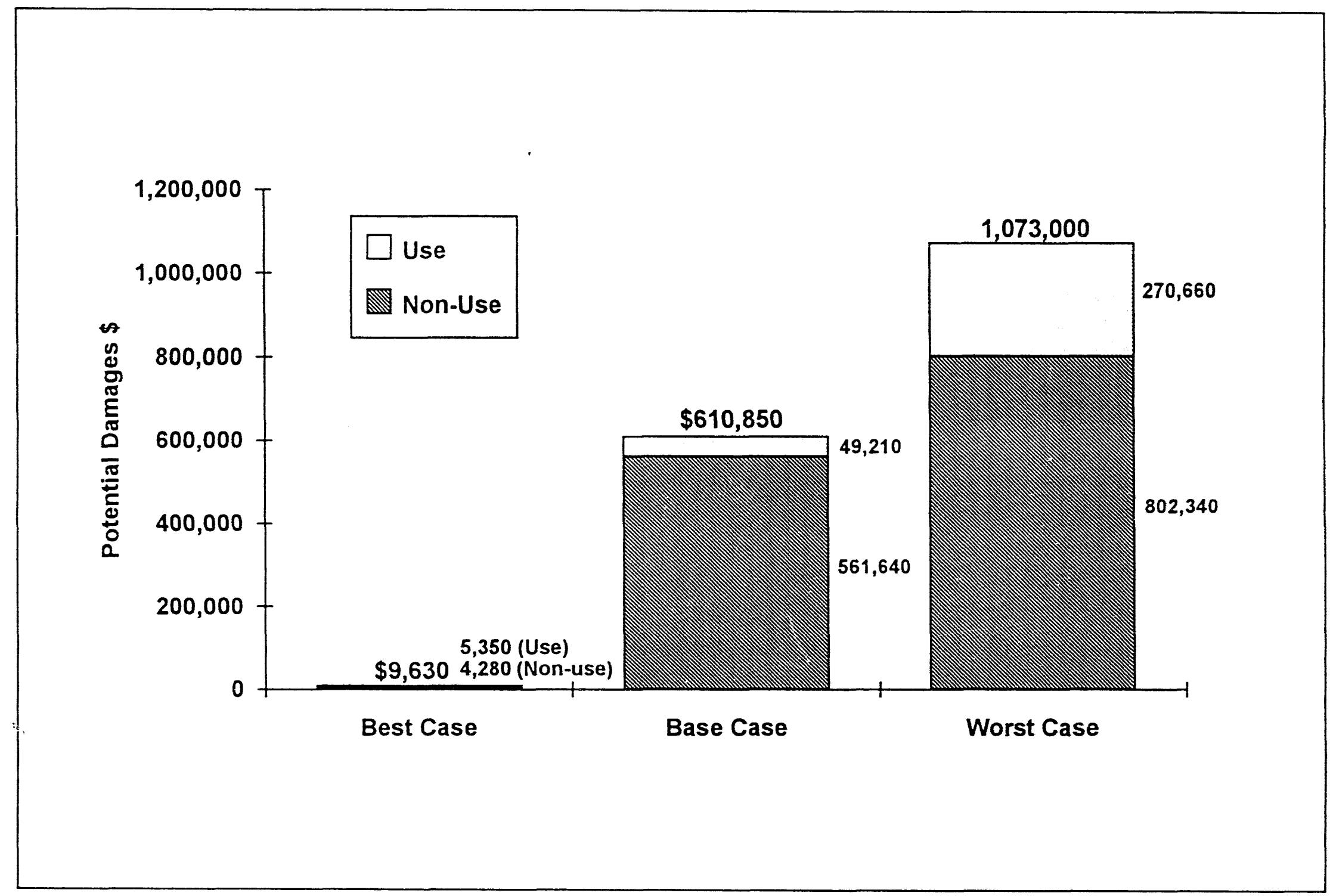

Exhibit 4-17:

RTI's estimated range of potential damage from Exxon's Arthur Kill oil spill.

(RTI, 1993). 
1) Only local boaters were affected; boaters wishing to pass through Arthur Kill were not analyzed.

2) Lost boating time due to the oil spill was fixed at 70 days, the actual period the Kill was shut down.

3) Boaters numbered 6 to 23 per day, based on number of local slips, and occupancy and participation rates.

4) Boating values ranged from $\$ 10$ to $\$ 70$ per day based on a published study on Colorado (presumably the only comparable study available to RTI).

Based on these assumptions, total boating-related damages were computed to range from $\$ 3,955$ to $\$ 221,480$, with a base case estimate of $\$ 31,640$ (Exhibit 4-17).

Bird Watching. RTI contacted officials at six area parks for data on bird watching during the period affected by the oil spill. The Arthur Kill area is surrounded by salt marshes and estuaries that serve as nurseries for more than 145 different species of fish and birds. Harbor herons and other large waterfowl are relatively abundant and the primary focus of bird watching activity in the area. RTI made the following assumptions to quantify damages to bird watching caused by the oil spill:

1) Only bird watchers visiting the six local parks were included.

2) A total of 1 to 10 bird watchers (out of 14 total users) were affected by the spill.

3) Lost bird watching time was fixed at 70 days.

4) Bird watching valuation ranged from $\$ 15$ to $\$ 45$ per day, with no independent analysis based on travel costs or analogous published reference cited.

Using these assumptions, RTI estimated bird watching damages caused by the Exxon oil spill to range from $\$ 1,425$ to $\$ 32,063$, with a base case estimate of $\$ 14,250$. Total direct use damages, which RTI assumed to involve only bird watching and boating, are summarized in Exhibit 4-17. These damages range from $\$ 5,000$ to $\$ 1,003,000$, with a mean estimate of $\$ 46,000$. 


\section{Non-Use Damages}

In addition to the direct use damages discussed above, RTI estimated the injury to nonuse services which the oil spill caused. Wetlands generally provide a wide array of non-use services, including flood hazard reduction, support of ecosystems through purification of waste, providing habitats for non-recreational birds and fish, etc. To assess the impacts of the Exxon oil spill on the Arthur Kill wetland, RTI relied on a Wetland Evaluation Technique (WET) study performed by the New York City Audobon Society on the affected area. WET is a standardized procedure which analyzes eleven components of wetland services, including groundwater discharge/recharge, wildlife diversity/abundance, recreation, and heritage. RTI then reviewed five published valuations of U.S. wetlands to obtain per-acre value estimates, selecting a study on a Louisiana wetland as the best analog. The following were the primary assumptions used in RTI's estimate of non-use resource damages:

1) The area of wetlands affected by the oil spill was estimated to range from 10 to 25 acres, based on Exxon's oil impact maps which show the extent of oiling. This is a small portion of the total 127 acres affected, most of which were channel areas rather than wetlands.

2) The length of time that the wetlands were impaired was estimated by RTI to range from 2 to 10 years; the analysis made the conservative assumption that gradual healing of the wetland would not occur, but did not cite independent analysis.

3) The non-use value of the wetland was estimated to range from $\$ 198$ to $\$ 3,000$ per acre, based on analogy to the Louisiana WET study. These values assume that the Arthur Kill was already seriously impaired in performing most non-use services, as indicated in a New York City Audobon Society report.

Based on these assumptions, RTI estimated total non-use damages to range from $\$ 3,960$ to $\$ 750,000$, with a base case estimate of $\$ 525,000$ (Exhibit 4-17). RTI's estimates of non-use damages accounted for the bulk of total damages, ranging from $44 \%$ to $92 \%$ of total estimated injury. 


\section{Critical Analysis}

Exxon's settlement of $\$ 15$ million for natural resources damages related to the Arthur Kill oil spill is to 15 to 1,500 times larger than the injury range quantified by RTI. However, there are several reasons why RTI's assessment may understate total natural resources damages caused by this oil spill. Two of the primary concerns with the methodology followed in RTI assessment include:

1) The use of a Louisiana wetland analog for Arthur Kill may have accurately captured nonuse services such as flood control and hydrologic stabilization. However, existence, option, and other difficult to quantify non-use values were also likely to have been damaged by the oil spill, but were not specifically addressed by the study. OPA 90 calls for the inclusion of these potential injuries to non-use resources in the case of major oil spills.

Despite the serious poliution of the Arthur Kill waterway, its location in the densely populated New York metropolitan area and the presence of sizeable heron and other large waterbird populations suggests that the oil spill caused a significant level of non-use damage. Currently, these non-use values are measurable only using the controversial contingent valuation method. Considering the potentially affected local population of several million people, and per-household damages averaging several tens of dollars in other CV studies of oil spills, these damages could easily have accounted for the balance of Exxon's settlement.

2) The costs of assessing natural resource damages were not included in the RTI study. These costs, reimbursement of which is provided under OPA 90, have been estimated to range from about $\$ 1$ per gallon to a staggering $\$ 25$ per gallon for the Exxon Valdez spill (Luthi et al., 1993), depending on coordination of private and public efforts and on the complexity of the damaged resource. Based on these unit assessment costs, this implies an additional cost of $\$ 567,000$ to $\$ 14$ million for assessment of the Arthur Kill oil spill, with the most likely estimate in the lower range.

Based on the reported actual costs incurred by Exxon for clean-up and prevention, the RTI estimates of use and non-use natural resource damages, and ARI's estimate of other non-use damages, total damages from the Exxon Arthur Kill oil spill are summarized in Exhibit 4-18. 
Total costs are estimated to range from $\$ 49$ million, for a relatively modest $\$ 5.5$ million in nonuse damages and \$0.6 million assessment costs, up to \$66 million or more using a more realistic $\$ 20.5$ million non-use damage estimate and $\$ 2.8$ million in assessment costs. Per-gallon estimates of total costs include $\$ 31.75 /$ gal for clean-up, $\$ 44.09 /$ gal for prevention, $\$ 1$ to $\$ 5 /$ gal for NRDA assessment costs, and $\$ 9.75$ to $\$ 36.20 /$ gal for non-use damages. 
Exhibit 4-18:

Estimates of natural resource damages related to Exxon Arthur Kill oil spill (Desvouges et al., 1993).

\begin{tabular}{|c|c|c|c|c|c|c|c|c|c|}
\hline & \multirow{2}{*}{$\begin{array}{l}\text { Cleanup } \\
\text { Costs }\end{array}$} & \multirow{2}{*}{$\begin{array}{l}\text { Capital } \\
\text { Losses* }\end{array}$} & \multirow{2}{*}{$\begin{array}{l}\text { Prevention } \\
\text { Costs }\end{array}$} & \multirow{2}{*}{$\begin{array}{c}\text { NRDA } \\
\text { Assessment } \\
\text { Costs* }\end{array}$} & \multicolumn{2}{|c|}{ Direct Use Damages } & \multicolumn{2}{|c|}{$\begin{array}{c}\text { Non-use } \\
\text { Damages }\end{array}$} & \multirow[b]{2}{*}{ Total* } \\
\hline & & & & & Boating & $\begin{array}{c}\text { Bird } \\
\text { Watching }\end{array}$ & $\begin{array}{l}\text { Wetlands } \\
\text { Services }\end{array}$ & $\begin{array}{c}\text { Existence } \\
\text { Option, Etc.* }\end{array}$ & \\
\hline $\begin{array}{l}\text { TOTAL } \\
\text { (Millions \$) }\end{array}$ & 18.0 & 0.2 & 25.0 & $0.6-2.8$ & 0.032 & 0.014 & 0.525 & $5-20$ & $49-66$ \\
\hline $\begin{array}{l}\text { PER GALLON } \\
1991 \text { (\$/gal) }\end{array}$ & 31.75 & 0.36 & 44.09 & $1-5$ & 0.06 & 0.03 & 0.93 & $8.82-35.27$ & $87.04-117.51$ \\
\hline 1993 \$/gal & 33.97 & 0.38 & 47.17 & $1-5$ & 0.06 & 0.03 & 0.99 & $9.44-37.73$ & $93.04-125.35$ \\
\hline
\end{tabular}

* ARI Estimates 


\subsubsection{Texaco Anacortes Refinery Spill}

\section{Introduction}

In the first judicial settlement for oil spill damages under OPA 90, Texaco agreed to resolve cleanup and damage costs related to a February 1991 oil spill at its refinery near Anacortes, Washington (Oil and Gas Journal, 1993). In February 1993, Texaco agreed to consent decrees in U.S. District Court at Seattle to settle suits brought by the Department of Justice, the EPA, and the Coast Guard. Although the still-proposed NOAA regulations governing oil spill damage assessment were not in place at the time of the spill or settlement, damage estimates by the state and NOAA reportedly followed these proposed procedures. Therefore, this case study provides an early indication of damage assessments under OPA 90.

The Texaco spill occurred when a refinery pump failed, causing about 210,000 gallons $(5,000 \mathrm{bbls})$ of crude oil to be spilled into Fidalgo Bay, which is part of Puget Sound. The Justice Department's case also referred to, but did not quantify, subsequent smaller releases of oil from the Anacortes refinery.

Cleanup costs and damages related to the Texaco Anacortes refinery spill, although not publicly released in complete detail, provide an additional case study complementing the Exxon Arthur Kill spill for the costs resulting from pipeline and refinery spills. In general, unit costs were considerably higher for the Texaco spill, due to its environmentally more sensitive location and, very likely, to the application of the new OPA 90 provisions.

\section{Cleanup Costs}

Under the U.S. District Court decree, Texaco was assessed cleanup costs of about $\$ 8.125$ million. In addition, the company is required to invest an additional $\$ 800,000$ in state-of-the-art spill prevention equipment. 


\section{Natural Resource Damages}

The methodology and detailed results from the assessment of natural resource damages are not available for the Texaco Anacortes spill. Texaco was assessed $\$ 480,000$ in civil penalties to the U.S. as natural resource trustee for unspecified damages. In addition, Texaco paid a $\$ 20,000$ penalty to Washington, under the state's newly promulgated Marine Oil Spill Compensation Schedule (see Section 3). Cleanup, prevention, and damage costs relating to the Texaco spill are summarized below, in 1993 dollars.

Exhibit 4-19:

Major components of 'Texaco's settlement from the 1991 Anacortes, Washington retinery spill (Oil and Gas Journal, 1993).

\begin{tabular}{||c|c|c|c|c||}
\cline { 2 - 5 } & Cleanup Costs & $\begin{array}{c}\text { Prevention } \\
\text { Costs }\end{array}$ & $\begin{array}{c}\text { Natural } \\
\text { Resource } \\
\text { Damages }\end{array}$ & Total Costs \\
\hline \hline $\begin{array}{l}\text { Total } \\
\text { (million) }\end{array}$ & $\$ 8,125,000$ & $\$ 800,000$ & $\$ 500,000$ & $\$ 9,425,000$ \\
\hline $\begin{array}{l}\text { Per Gallon } \\
\text { (per gal) }\end{array}$ & $\$ 38.69$ & $\$ 3.81$ & $\$ 2.38$ & $\$ 44.88$ \\
\hline
\end{tabular}




\subsection{Offshore Platform Spills}

\subsubsection{Union/Texaco Platform (Santa Barbara, California)}

On January 28, 1969, a blowout occurred at Union Oil Company's Platform A in the Santa Barbara Channel, California during the drilling of a routine oil development well. Union's Platform A had been drilling in federal waters (Lease 402) about 5.5 miles offshore of Santa Barbara, when crude oil erupted from the sea floor around the wellhead (Exhibit 4-20). During the following three weeks, the well released an estimated 21,000 gallons (500 bbls) per day, creating a $25-\mathrm{mi}^{2}$ slick of some 441,000 gallons of crude oil.

The Santa Barbara oil spill, while comparable in size to hundreds of other tanker spills that have occurred in the U.S. over the past several decades (sec. Appendix 1), proved to be a significant turning point in heightening awareness of the environmental effects of oil spills.

\section{Cleanup and Prevention Costs}

From the outset of the Santa Barbara oil spill, it was apparent that Union Oil was unprepared to handle a spill that large. Because the company's production personnel were busy trying to plug the well, needed personnel were brought in from other divisions within the company, particularly the refining division. Neither these personnel nor the contractors hired to assist in clean-up operations had been properly trained in oil spill prevention and containment. Cleanup operations began with the application of 10,000 gallons of dispersant to break up the slick before it reached the coastline. Inflatable plastic booms were also employed, but were relatively ineffective because of heavy seas and breaches in the booms. Wooden booms were then constructed for containment, but they broke apart in heavy seas.

The Santa Barbara blowout posed a unique containment problem. Oil was not only gushing from the wellbore, but from natural fractures connecting thu oil reservoir with the surface as well. Natural oil seeps are common within the Santa Barbara area (most notably Coal 


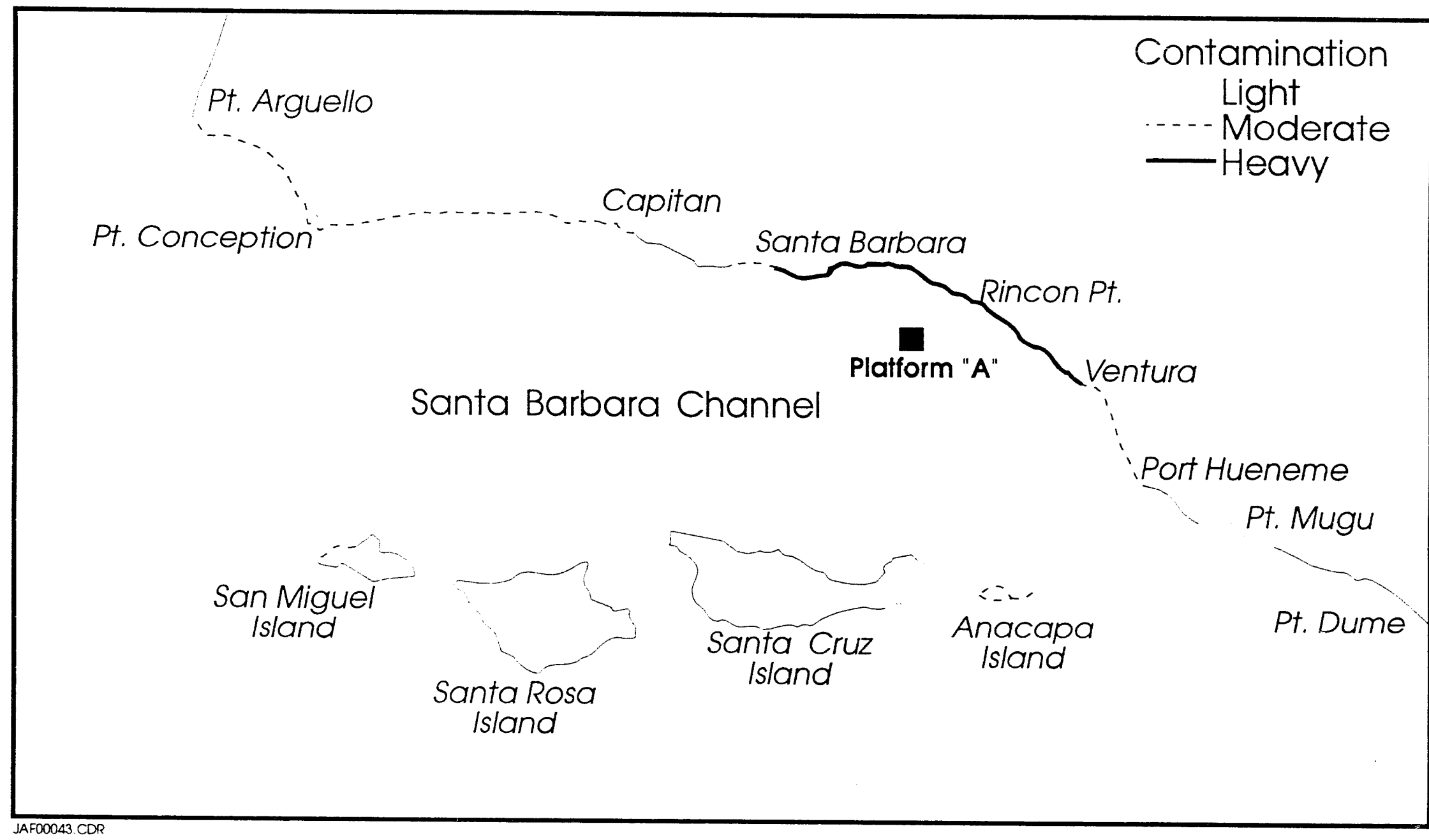

Exhibit 4-20:

Area contaminated with oil from Union Oil Co. Platform A by March 30, 1969.

(Source: U.S. Coast Guard) 
Oil Point), created as oil migrates up through fractures in the rock. Some of the natural seeps in the area reportedly produce oil at nearly twice the estimated 500 barrels per day rate of the Union Oil blowout (Gaines, 1969). An innovative system of underwater hoods or tents was installed on the ocean floor to collect the seeping oil and carried via flexible tubing to storage tanks on the platform. This underwater collection system covered approximately 40,000 square feet of the ocean floor.

Total cleanup costs for the Santa Barbara spill were estimated to be $\$ 5$ million $(\$ 18.1$ million in 1993 dollars; Gaines, 1969).

\section{Capital Losses}

The major capital loss as a result of the Santa Barbara spill was the value of the spilled oil. Based on Union Oil's estimate of 10,000 barrels of spilled oil, and contemporary oil prices of $\$ 3.50 /$ barrel, the value of the lost oil was $\$ 35,000$ in 1969 , or $\$ 127,000$ in 1993 dollars.

\section{Resource Damages}

Prior to the Santa Barbara spill, there were no federal statutes in effect for assessing resource damages from oil spills. At the time, the Federal Water Pollution Control Administration (FWPCA) was the only agency empowered to deal with oil spills, but assessment of natural resource damages was not within its charter. It is likely that non-use damages resulting from the Santa Barbara oil spill would have been substantial, had a damage assessment been performed under present day CERCLA and OPA 90 regulations.

The media coverage of the damage caused by the Santa Barbara spill was extensive and the pictures of oiled birds and tar on the beaches were familiar to most everyone at the time. Given the widespread public awareness of the spill, and the actual amount of oil spill and natural resource damages, it is plausible that non-use damages would have been perhaps one-third of those assessed for the Exxon Valdez spill. In the Valdez assessment, it was determined that each household would be willing to pay $\$ 31.00$; therefore, the Santa Barbara household WTP may arguably be in the range of $\$ 10$. Based on $90,000,000$ U.S. households, the Santa Barbara oil 
spill may have caused a total of $\$ 900$ million in non-use damages. On a per-gallon basis, this would make Santa Barbara the most costly spill for non-use damages, at some $\$ 2,143.00 /$ gallon.

\section{Critical Analysis}

The cleanup costs of the Santa Barbara oil spill were relatively high, $\$ 43.16 /$ gallon (1993\$), based on the size and location of the spill. The bulk of the cleanup costs at Santa Barbara were spent on high-impact methods such as steam cleaning, hydroblasting, bulldozing, and scraping to clean beaches, rocky areas, and harbors and marinas. Subsequent research into oil spill cleanup methods has demonstrated that these aggressive, high-impact techniques can actually exacerbate oil spill damages and further degrade the environment.

Cleanup at Santa Barbara was also made more difficult by local oceanographic and geographic factors. The waters in the Santa Barbara Channel are relatively cold, which tends to retard the natural degradation of oil by bacteria. Furthermore, the Santa Barbara area presents a diverse set of environments, including islands, coastal wetlands, rocky beaches, sandy beaches, salt marshes, tidal flats and harbors. 


\subsubsection{Ixtoc Platform (Gulf of Mexico)}

The IXTOC 1 well sufiored a blowout on June 3,1979, resulting in the largest documented oil spill into the marine environment to date. Over the nine-month period which lasted until March 23, 1980, when the well was finally plugged, the IXTOC 1 well released an estimated 125 to 210 million gallons ( 3 to 5 million barrels) of crude oil into the Gulf of Mexico. It is estimated that one-half of the oil released was burned and one-half spilled into the Gulf. Of the 60 to 105 million gallons which escaped into the sea, approximately 1 million to 3 million gallons impacted the south coast of Texas.

The IXTOC 1 well was drilled by Petroleos Mexicanos (PEMEX), the Mexican stateowned oil company, 50 miles off of the Yucatan Peninsula in the Bay of Campeche, about 500 miles soutin of Texas (Exhibit 4-21). Fortunately, because of extensive previous oceanographic research of the currents in the Gulf of Mexico, it was possible to accurately predict the path of the drifting oil slick. Computer simulations predicted that the slick would move northward, well off the nearest Mexican shores, with the heaviest concentrations of oil expected to wash ashore along the Texas coast.

Despite being the largest oil spill in history, natural resource damages caused by the IXTOC 1 spill were surprisingly small. This relatively light damage was clue largely to a combination of favorable oceanographic conditions, which kept the bulk of the oil from washing ashore, and to subtropical climatic conditions which promoted the rapid natural degradation of the oil.

\section{Cleanup and Prevention Costs}

Immediately following the blowout, several oil well control specialists were brought in, but were unable to bring the well under control. The only method considered to be effective to stem the blowout was to drill two relief wells, the IXTOC IA and IXTOC 1B, but it would require several months before they could be drilled and put into operation. In the interim, more than 4.5 million barrels of fluids and gels were injected into the well along with over 100,000, 3-inch diameter steel and lead balls. By the time the last of the cement plugs were rammed into 


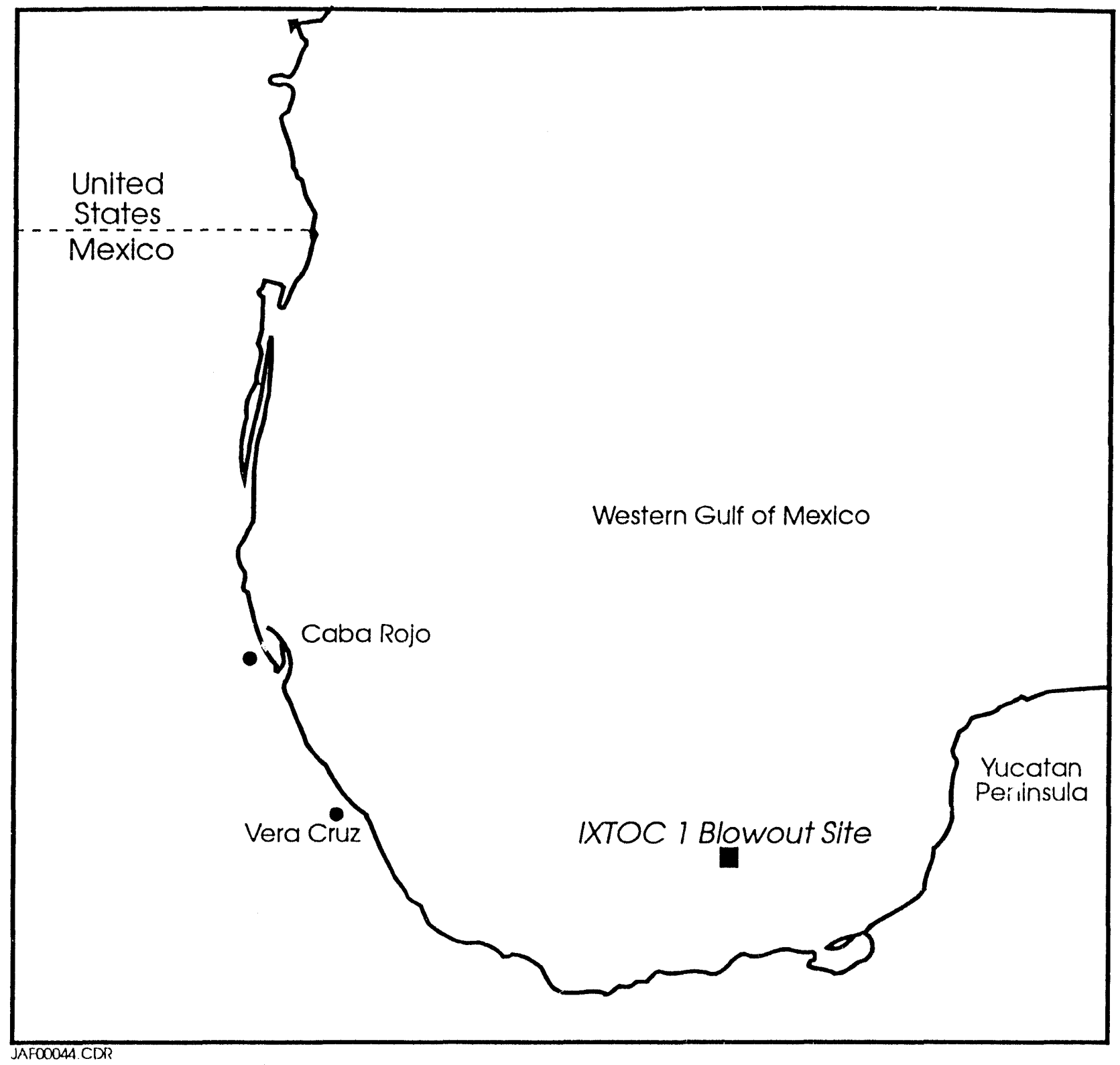

Exhibit 4-21

Location of the Ixtoc I blowout site in the western Gulf of Mexico.

the IXTOC 1 through the two relief wells, PEMEX had spent an estimated $\$ 82$ million on capping the well and $\$ 50$ million on cleanup and containment.

Because the majority of the spill was predicted to come ashore on U.S. coastal areas, the U.S. Coast Guard was activated on June 9, under authority of the National Oil and Hazardous Waste Materials Contingency Plan (NCP). The Coast Guard estimated its cleanup operations cost $\$ 75,000$ per day, for a total cost of $\$ 8$ million to $\$ 10$ million. At the state level, Texas spent just over $\$ 330,000$ on cleanup operations. 


\section{Capital Losses}

The semi-submersible platform which had drilled the IXTOC 1 well ignited soon after the blowout and was scuttled, for a capital loss of $\$ 21$ million. In addition, the value of the estimated 3 to 5 million barrels of spilled oil was approximately $\$ 87$ million (Waldichuk, 1980). Therefore, capital losses due to the IXTOC 1 oil spill amounted to about \$108 million (\$199.4 million in 1993\$).

\section{Economic Impact Study}

The U.S. Bureau of Land Management funded a damage assessment study performed by an El Paso, Texas based consulting firm (Restrepo et al., 1982). The report analyzed both the direct and indirect economic impacts of the spill on tourism, recreation, and commercial fisheries in Texas coastal counties. Due to contract specifications and budget limitations, a nonsurvey "output" approach was employed.

Under the survey, the economic impact of the oil spill was assumed to be limited to (1) the current direct economic impacts on tourism, recreation, and commercial fisheries; and, (2) the current indirect or "induced by" economic effects of the supportive or related economic activities located in the study region. Direct economic impacts were measured by the development of a density gradient model for each of the economic sectors studied as classified by the Standard Industrial Classification (SIC). The composition of each industry is:

Recreation: recreation services, other retail trade.

'Tourism: Eating and drinking establishments, automobile services, lodging.

Commercial fishing: Finfish, shellfish, miscellaneous fish.

Using this method, a density gradient of 100 percent indicates that the economic establishments suffered a total loss of business activity, whereas a relative density gradient of 0 percent indicates no loss. The relative density gradient models were constructed through qualitative assessments of direct economic impacts via on-site interviews and resulting quantitative impact assessments. 
Indirect economic effects were assessed using an input-output model based on a transactions table, which is a system of accounts of inter-industry transactions. A direct requirements table is also calculated from information contained within the producing sector's purchases. Economic impacts are then measured by change in regional sales to final demand, presented on a third table, the total requirements table.

Tourism. Gross receipts data for SIC-coded tourist establishments were obtained from the Texas Comptroller's office and the Department of Highways and Public Transportation. In addition, interview data were collected from 38 businesses and tourist agencies. Total estimated direct losses to the tourism industry in Texas from the Ixtoc I spill were estimated to range from $\$ 3.9$ million to $\$ 4.4$ million. The South Padre Island area accounted for an estimated 50 percent of total estimated direct tourism losses. Indirect tourism losses were estimated to be about onefourth of direct losses, for an additional loss of $\$ 950,000$ to $\$ 1.1$ million.

Recreation. Data relative to sales in SIC-coded recreation-related categories were secured from the Texas Comptroller's office and used to generate a trend line for each recreation sector. Owners of recreation establishments were interviewed to obtain information on the extent of losses; these interviews were used to adjust the estimated percentage of lost income, since nearly all of the losses were incurred in Gulf-front communities. Lost sales reports were discounted based on a ratio of general retail sales at the county level and the Gulf-front communities. Calculated losses, in terms of gross receipts, indicate a total direct economic loss to the recreation industry of $\$ 3.1$ million. Indirect losses were estimated to be approximately one-third the value of direct losses, for an additional $\$ 855,000$.

Commercial Fishing. The Gulf of Mexico is a rich source of many varieties of fish, representing one of the largest commercial industries in this region of the U.S. Total dockside value of shell and finfish landed in Texas in 1978 was $\$ 125.5$ million dollars (Woods and Hannah, 1981). Consequently, the Ixtoc I blowout created concern within the commercial fishing industry about potential fishing losses.

Data were obtained on landing, effort, and value for the commercial fishing industry from the National Marine Fisheries Service and the Texas Parks and Wildlife Department. 
Additional data were obtained through survey interviews of fishermen, dealer, biologists, marine advisory agents, and local businesses. These data indicated that the commercial fishing industry of Texas did not suffer measurable direct or indirect economic effects as a result of the IXTOC 1 spill.

\section{Critical Analysis}

The Restrepo and Associates study was performed prior to the enactment of CERCLA and OPA statutes and therefore does not quantify non-use damages to coastal areas. It is likely that non-use damages would have been limited, particularly considering the size of the spill, given that only subtle changes in the bird and infaunal populations were detected (less than 10 percent of wading and shore birds observed in affected coastal areas were oiled) and there was no apparent damage to estuarine areas (Woods and Hannah, 1981). ARI estimates that had the spill been assessed under OPA 90 regulations, non-use damages would have been 10 to 20 percent of the value placed on the Valdez assessment, or $\$ 280$ to $\$ 560$ million.

Reported actual costs for capping the well, clean-up and containment, and direct and indirect damages from the IXTOC 1 blowout are summarized in Exhibit 4-22. Total estimated costs for clean-up and containment range from $\$ 140$ million to $\$ 142$ million, while direct use danages were assessed at between $\$ 8.8$ million and 9.5 million. Per gallon estimates of d.mages include $\$ 3.23 /$ gal to $\$ 3.28 /$ gal for clean-up, $\$ 0.11 /$ gal to $\$ 0.13 /$ gal for direct use damages, and $\$ 2.49 /$ gal for capital losses, including the drilling platform and the value of the lost oil.

The magnitude of the IXTOC 1 blowout focused attention to offshore drilling operations and the likelihood of another major blowout occurring. A study performed in wake of the Ixtoc I incident indicated that the risks of blowouts on offshore platforms were very low (Waldichuk, 1980). The study demonstrated that out of 19,000 production wells in operation in the OCS during 1973, fewer than 0.25 percent blew out during their lifetimes. Furthermore, gas wells accounted for $87 \%$ of OCS blowouts, with less than 13 percent of blowouts involving oil wells. 
Exhibit 4-22:

Summary of damages from the Ixtoc I blowout.

\begin{tabular}{|c|c|c|c|c|c|c|c|}
\hline & & & \multicolumn{3}{|c|}{ Direct Use Damage } & \multirow[b]{2}{*}{$\begin{array}{c}\text { Non-Use } \\
\text { Damages* }\end{array}$} & \multirow[b]{2}{*}{ Total } \\
\hline & $\begin{array}{c}\text { Cleanup } \\
\text { Cost }\end{array}$ & $\begin{array}{l}\text { Capital } \\
\text { Loss }\end{array}$ & Tourism & Recreation & $\begin{array}{l}\text { Commercial } \\
\text { Fishing }\end{array}$ & & \\
\hline $\begin{array}{l}\text { Total } \\
1979 \mathrm{~S} \\
\end{array}$ & $140-142$ & 108 & $4.8-5.5$ & 4.0 & -- & $280-560$ & $536.8-819.5$ \\
\hline $\begin{array}{l}\text { Total } \\
1993 \$\end{array}$ & $258.4-262.1$ & 199.4 & $8.9-10.1$ & 7.4 & -- & $516.8-1,033$ & $990.9-1,512.8$ \\
\hline $\begin{array}{l}\text { Spill Unit } \\
\text { Values } \\
1993 \text { \$/gal }\end{array}$ & $3.23-3.28$ & 2.49 & $0.11-0.13$ & 0.09 & -- & $6.46-12.91$ & $12.38-18.90$ \\
\hline
\end{tabular}

* Assumes that non-use damages assessed would have been 10 to 20 percent of those assessed for the Exxon Valdez spill because actual coastal damages were minimal. 


\section{Conclusions}

This analysis of oil spill damage assessment methodology, regulations, and published case studies of oil spill costs has generated five primary conclusions, summarized as follows:

1) Analysis of natural resuurce damage assessment methodology indicates that the methods suggested for use in OPA 90 and the proposed NOAA regulations generally are theoretically robust and widely accepted by the economic research community, indicating that these regulation are likely to be promulgated largely as proposed. However, the implementation of contingent valuation surveys remains highly controversial. The most important sources of potential error in CV studies is the definition of the affected population, the use of schedules to guide valuation responses, embedding, "warm glow" effects, and a number of other aspects concerning implementation.

2) Tanker spills have the highest range in total spill unit cost values. Tanker spill costs ranged from a low average of about $\$ 5$ per gallon spilled for the Amazon Venture and the four Mercer tanker settlements, to a high of about $\$ 569$ per gallon for the Exxon Valdez spill (Exhibit 5-1 and Exhibit 5-2). Large variations were observed in all cost categories, particularly cleanup costs, and direct use and non-use natural resource damages. For the two large and well documented Alaskan tanker spills, cleanup costs varied from $\$ 18.58$ to $\$ 257.00$ per gallon, direct use damages varied from $\$ 5.16$ to $\$ 363$ per gallon, and non-use damages varied from an estimated $\$ 5.46$ to $\$ 283.99$ per gallon. This extreme variation occurred despite the fact that the Exxon Valdez and the S.S. Glacier Bay occurred in comparably sensitive environmental locations and were both prosecuted under the CERCLA regulatory framework.

3) Pipeline and refinery spills tend to cause lower and more uniform natural resource damages than do tanker spills. Cleanup costs for the two case studies were of moderate size and similar at $\$ 33.97$ and $\$ 38.69$ per gallon, reflecting the wetland environments that these installations tend to affect. Direct use damages were relatively minor, due to the typically industrialized setting of these facilities. Non-use damages due to 
pipeline/refinery spills have not been rigorously analyzed but, based on their industrialized location, may be much less than for tankers.

4) Offshore facilities spills have been rare in recent years due to improved operational safety, but the scarce data available indicate that spill unit values can vary widely, similar to those for tanker spills. Cleanup costs varied ten-fold for the two spills examined, Ixtoc and Santa Barbara. Direct use damages in the typically open marine environment of OCS platforms are anticipated to be lower than for pipeline/refinery facilities or for tanker spills in sensitive coastal areas. Non-use values, such as option and existence values, are the major unknown factors in quantifying the economic impacts of offshore facilities spills. A major oil spill in coastal California could generate non-use spill cost unit values comparable to those measured for the Exxon Valdez. Spill unit values for platforms are estimated to range from $\$ 12$ to $\$ 143$ per gallon (or conceivably an order of magnitude higher), with non-use values measured using contingent valuation the major unknown.

5) In addition to spill unit cost values of economic damages from oil spills, it is also necessary to consider spill risk in designing effective oil cpill research and development. Coast Guard records indicate that tanker spills occur most frequently, with pipeline/refinery spills less frequent, and offshore facility spills quite rare. Analysis of the spill impact data indicates that R\&D focused on tanker spills would be the most cost-effective in reducing spill costs and impacts. Pipeline/refinery research would be the next most important oil supply component to be targeted for oil spill R\&D, because spill unit values for these facilities are moderately high at $\$ 45$ to $\$ 125$ per gallon and because these accidents are next most frequent following tanker spills. Offshore facilities have the potential to generate large non-use damages, but are infrequent; thus offshore facilities are not strongly recommended for oil spill $R \& D$.

To gauge the overall impacts of oil spills on the economy, it is instructive to estimate the total dollar losses which have occurred during the past two decades. Physical data concerning tanker oil spills in U.S. waters are maintained by the U.S. Coast Guard; Appendix I lists all 
major (>100,000) spills that took place during the period 1973 through 1990. During this period, tankers accounted for the overwhelming proportion of oil spills. Exhibit 5-3 summarizes the volume of oil spilled annually in major incidents during this period, amounting to a cumulative total of some 88 million gallons.

The spill unit cost ranges developed by this study can provide an approximation of the economic impacts inflicted by these oil spills. Based on the U.S. Coast Guard oil spill volumes, and the per-gallon cost range developed from the analysis of tanker spills (Exhibit 5-2), ARI estimated the total annual cost of cleanup and natural resource damages due to oil spills in the U.S. (Exhibit 5-4). Using an average value of $\$ 287$ per gallon spilled for total cleanup and damages, calculated by averaging the tanker spill cost range of $\$ 5$ and $\$ 569$ per gallon, the estimated annual losses due to oil spills ranged from under $\$ 1$ billion per year to as much as $\$ 3.26$ billion in 1989 (1993\$). Total costs over the period 1973 to 1990 due to U.S. oil spills amounted to an estimated $\$ 25$ billion dollars in 1953 dollars (adjusted for inflation, but not compounded to reflect alternative investment value of money). This value reflects a staggering loss to the U.S. economy and underscores the need for developing effective oil spill prevention, response, and cleanup technology. 
Exhibit 5-1:

Summary of per-bbl costs and damages from marine oil spills. (All values in $1993 \$$ gal)

\begin{tabular}{|c|c|c|c|c|c|c|c|c|}
\hline & $\begin{array}{l}\text { Cleanup } \\
\text { Costs }\end{array}$ & $\begin{array}{l}\text { Capital } \\
\text { Losses* }\end{array}$ & $\begin{array}{l}\text { Prevention } \\
\text { Costs }\end{array}$ & $\begin{array}{l}\text { NRDA } \\
\text { Costs }\end{array}$ & $\begin{array}{l}\text { Direct Use } \\
\text { Damages }\end{array}$ & $\begin{array}{l}\text { Non-Use } \\
\text { Damages }\end{array}$ & Total* & $\begin{array}{c}\text { Actual } \\
\text { Settlement } \\
\text { and Costs }\end{array}$ \\
\hline \multicolumn{9}{|l|}{ Tanker } \\
\hline Glacier Bay & 18.58 & 0.43 & -- & -- & 363.51 & $5.46^{*}$ & 390 & -- \\
\hline Exxon Valdez & 257.00 & 0.40 & -- & $9.91-19.81$ & 13.67 & 283.99 & $564-574$ & 370.00 \\
\hline Amazon Venture & $2.75^{*}$ & 0.35 & -- & 0.26 & 0.86 & 1.71 & 5.93 & 3.00 \\
\hline $\begin{array}{l}\text { Mercer Data } \\
\text { Base }\end{array}$ & -- & -- & -- & -- & -- & -- & -- & $4.15-37.90$ \\
\hline \multicolumn{9}{|l|}{ Pipeline/Refinery } \\
\hline $\begin{array}{l}\text { Exxon Arthur } \\
\text { Kill }\end{array}$ & & 0.38 & 47.17 & $1-5^{*}$ & 0.09 & $10.43-38.72$ & $93-125$ & 109.35 \\
\hline $\begin{array}{l}\text { Texaco } \\
\text { Anacortes }\end{array}$ & 38.69 & 0.08 & 3.81 & -- & 2.38 & -- & 45 & 44.88 \\
\hline \multicolumn{9}{|l|}{ Offshore Platform } \\
\hline Ixtoc & 3.25 & 1.43 & - & -- & 0.21 & $6.5-12.9^{*}$ & $11-18^{*}$ & -- \\
\hline Santa Barbara & 43.16 & 0.30 & -- & -- & - & $50->100 *$ & $93->143^{*}$ & -- \\
\hline
\end{tabular}

*ARI Estimate 


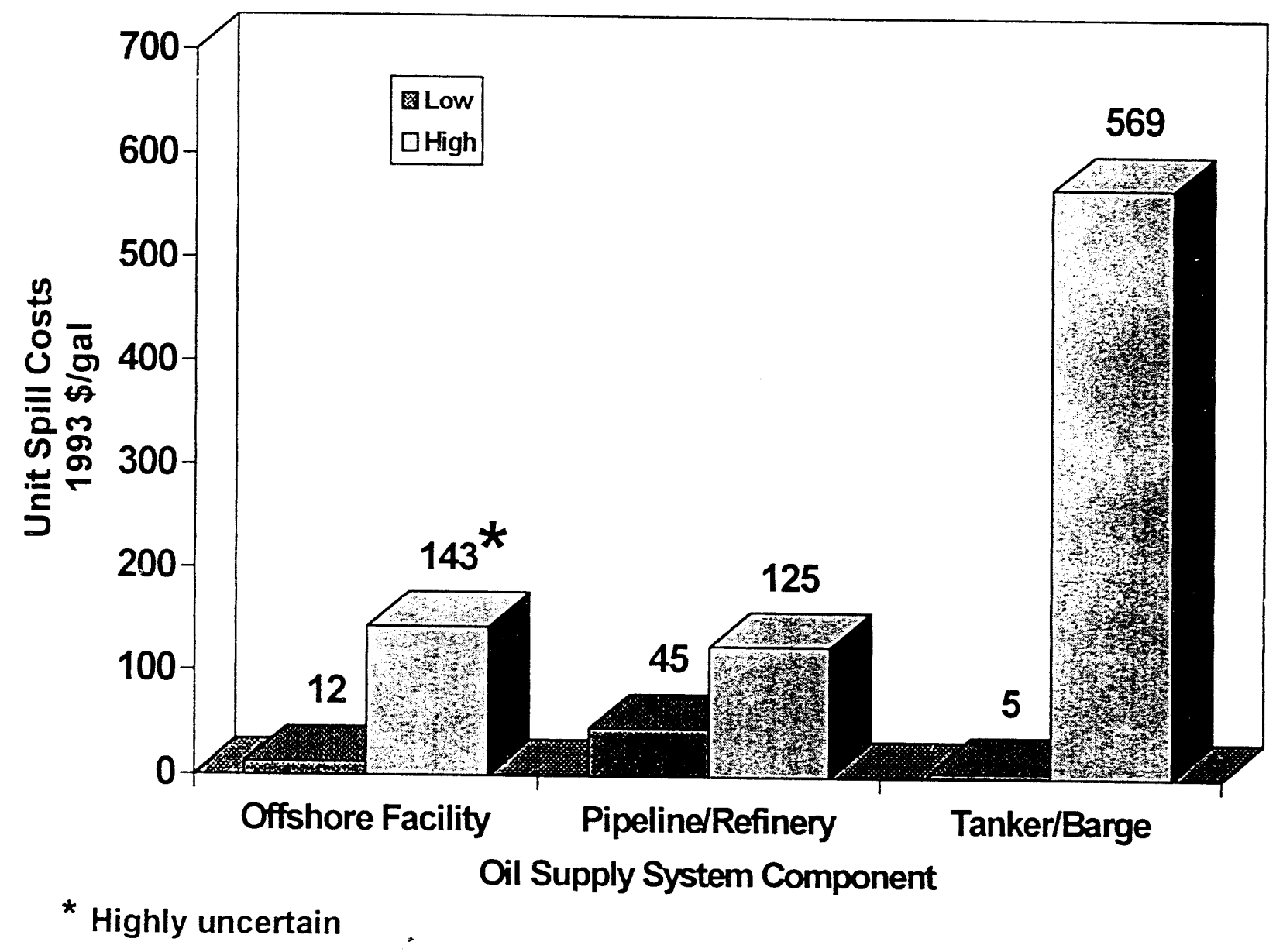

Exhibit 5-2:

Most likely ranges of spill unit costs for three oil supply components. 


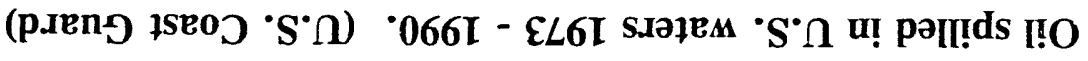

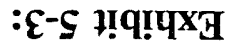

נеә人

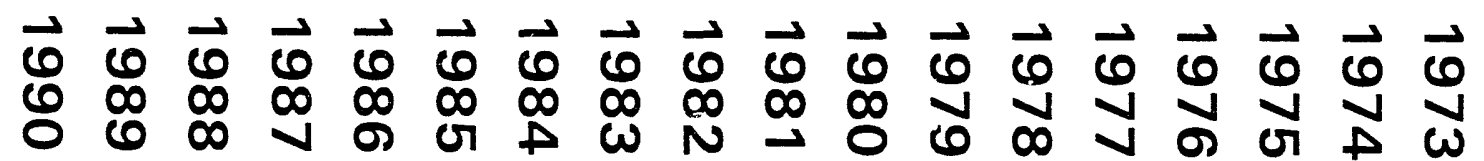
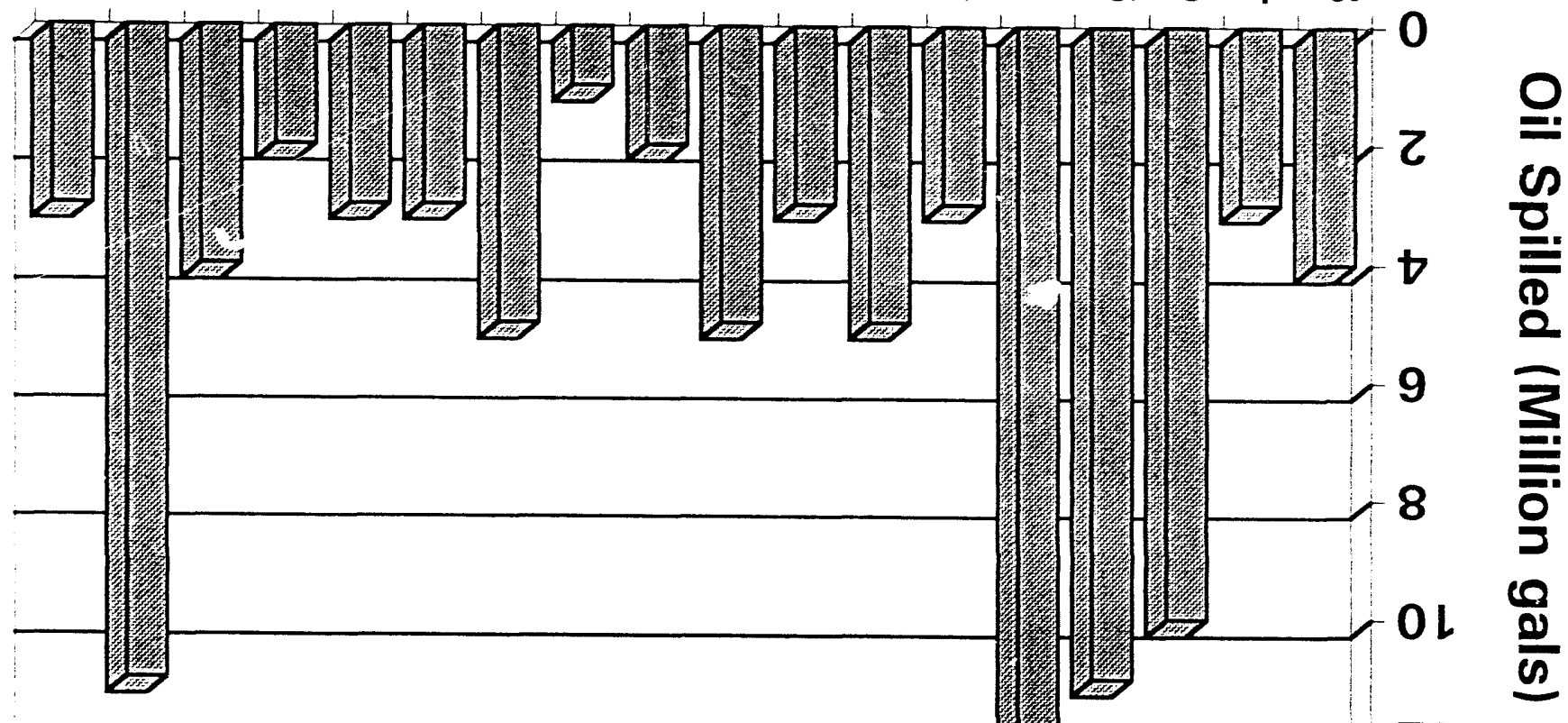


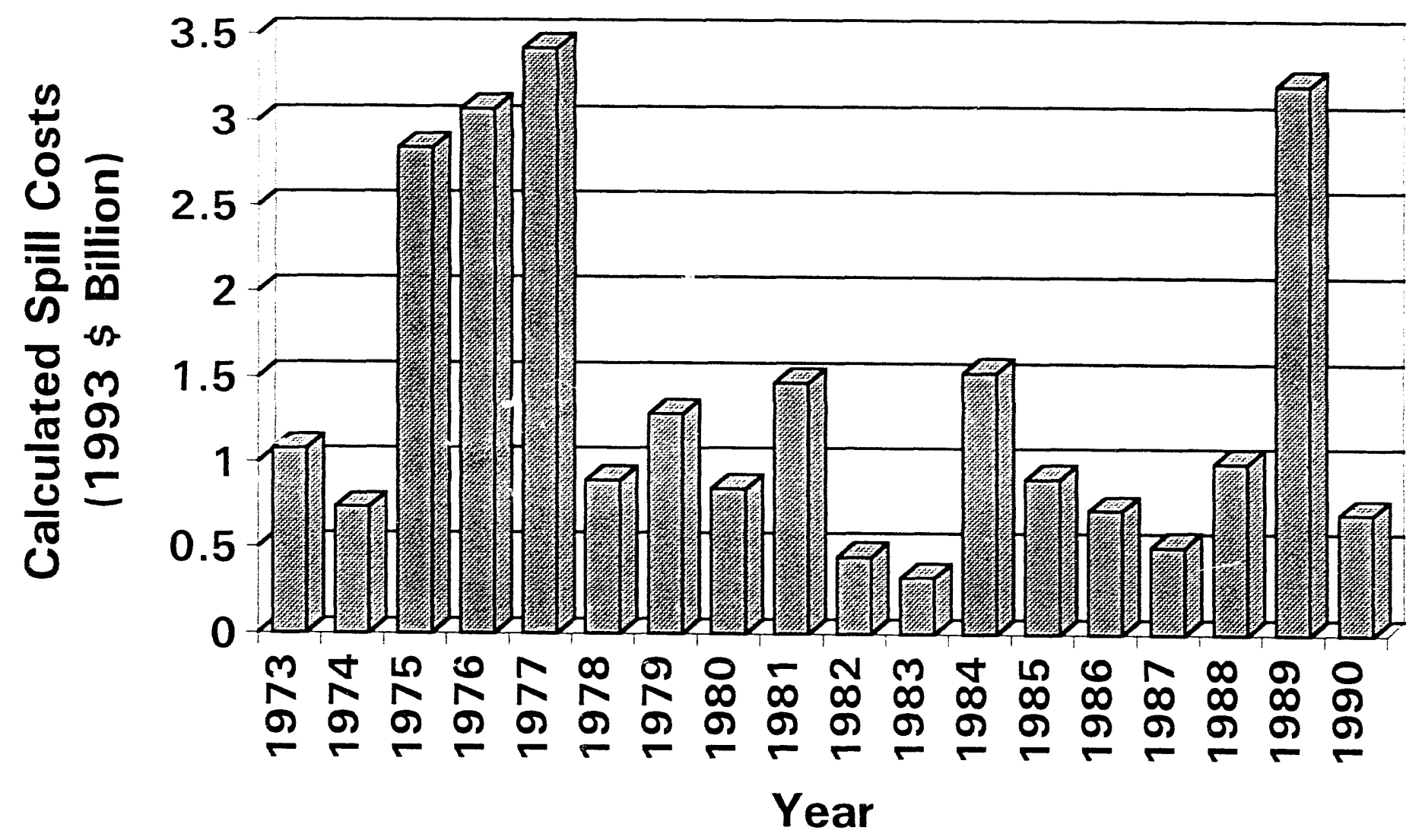

Exhibit 5-4:

ARI's calculated damages due to oil spilled in U.S. waters based on average spill unit cost $(\$ 283 / \mathrm{gal})$. 


\section{References}

B-Laing Associates, 1990. "Arthur Kill, Kill van Kull, and Tributaries: General Wetland Summary," final draft report, prepared for Exxon USA, August.

Bishop, R.C. and Heberlein, T.A., 1992. "The Contingent Valuation Method," in K.W. Ward and J.W. Duffield, eds., Natural Resource Damages: Law and Economics, John Wiley, New York, p. 281-309.

Boehm, P.D., Fiest, D.L., Kaplan, I., Mankiewicz, P., and Lewbel, G.S., 1983. "A Natural Resources Damage Assessment Study: The IXTOC 1 Blowout," 1983 Oil Spill Conference, San Antonio, Texas, February 28-March 3, p. 507-515.

Brown, G., 1992, "Replacement Costs of Birds and Mammals," Report prepared for Alaska Attorney General, December, $16 \mathrm{p}$.

Burden, P., Isaacs, J., Richardson, J., Braund, S., Witten, E., and Moorehead, L., 1990. Economic Impacts of the S.S. Glacier Bay Oil Spill," Report prepared for Minerals Management Service, Alaska Outer Continental Shelf Region, November, $91 \mathrm{p}$.

Carson, R.T. and Hanemann, W.M., 1992, "A Preliminary Economic Analysis of Recreational Fishing Losses Related to the Exxon Valdez Oil Spill," Report prepared for Alaska Attorney General, December, $14 \mathrm{p}$.

Carson, R.T., Mitchell, R.C., Hanemann, W.M., Kopp, R.J., Presser, S., and Ruud, P.A., 1992. "A Contingent Valuation Study of Lost Passive Use Values Resulting from the Exxon Valdez Oil Spill," Report prepared for Alaska Attorney General, November, 312p.

Dean, T.A., McDonald, L., Stekoll, M.S., and Rosenthal, R.R., 1993. "Damage Assescment in Coastal Habitats: Lessons Learned from Exxon Valdez," Proceedings of the 1 y93 International Oil Spill Conference, Tampa, Florida, p. 695-697

Desvousges, W.H., Dunford, R.W., Mathews, K.E., Banzhaf, H.S., 1993. "NRDA Case Study: The Arthur Kill Oil Spill," Proceedings of the 1993 International Oil Spill Conference, Tampa, Florida, March 29-April 1, p. 711-716.

Diamond, P.A., Hausman, J.A., Leonard, G.K., and Denning, M.A., 1992. "Does Contingent Valuation Measure Preferences?," Paper presented at the Cambridge Economics, Inc. Symposium, Contingent Valuation: A Critical Assessment, Washington, D.C., April.

Dunford, R.W., Hudson, S.P., Desvousges, W.H., 1993. "Experimental Contingent Values for Reducing Environmental Damage from Oil Spills," Proceedings of the 1993 International Oil Spill Conference, Tampa, Florida, p. 699-703.

Energy Resources Co., Inc., 1982. "IXTOC Oil Spill Assessment," report prepared for U.S. Bureau of Land Management, April, 37 p. 
Exxon USA, 1991. Civil Consent Order, June 14.

Gaines, T.H., 1969. "Pollution Control at a Major Oil Spill," Joint Conference on Prevention and Control of Oil Spills, Proceedings, New York, December 15-17, p. 271-280.

Geselbracht, L. and Logan, R., 1993. "Washington's Marine Oil Spill Compensation Schedule - Simplified Resource Damage Assessment," Proceedings of the 1993 International Oil Spill Conference, Tampa, Florida, March 29-April 1, 1993, p. 705-709.

Grigalunas, T.A. and Opaluch, J.J., 1993. "Non-Use Value in Natural Resource Damage Assessments: The Nestucca Oil Spill," Proceedings of the 1993 International Oil Spill Conference, Tampa, Florida, p. 689-693.

Grigalunas, T.A. and Opaluch, J.J., French, D.P., and Reed, M. 1992. "Validating a Type A Assessment Model," in K.M. Ward and J.W. Duffield, eds., Natural Resource Damages: Law and Economics, John Wiley \& Sons, Inc., New York, p. 471-491.

Grigalunas, T.A. and Opaluch, J.J., 1988. "Assessing Liability Damages Under CERCLA: A New Approach for Providing Incentives for Pollution Avoidance?" Natural Resources Journal, v. 28, p. 509-533.

Harrison, O.R., 1991. "An Overview of the Exxon Valdez Oil Spill," Proceedings of the 1991 Oil Spill Conference, San Diego, March 4-7, p. 313-319.

Lindstedt-Siva, J., 1979. "Resources Sensitive to Oil Spills (Case Study of the Santa Barbara Channel)," Proceedings of the 1979 U.S. Fish and Wildlife Service Pollution Response Workshop, St. Petersburg, Florida, May 8-10, p. 79-90.

Luthi, R.B., Burlington, L.B., Reinharz, E., and Shutler, S.K., 1993. "The Second Generation of Natural Resource Damage Assessments: Lessons Learned?, " Proceedings of the 1993 International Oil Spill Conference, Tampa, Florida, March 29-April 1, p. 727-731.

Mazzotta, M.J., Opaluch, J.J., and Grigalunas, T.A., Restoration and Natural Resource Damage Assessment," Proceedings of the 1993 International Oil Spill Conference, Tampa, Florida, March 29-April 1, 1993, p. 721-725.

McDowell Group, 1990, "An Assessment of the Impact of the Exxon Valdez Oil Spill on the Alaska Tourism Industry," Report prepared for Preston, Thorgrimson, Shidler, Gates, and Ellis, August, 96 p.

Mendelsohn, R., 1986. "Assessment of Damages by PCB Contamination to New Bedford Harbor Amenities Using Residential Property Values," Draft Report for NOAA.

Mercer Management Consulting, 1992. "OPA 90: Regulatory Impact Analysis Review," Interim Report for U.S. Coast Guard, September 15.

Michel, J., 1989, "Natural Resource Damage Assessment of the Amazon Venture Oil Spill," 1989 Oil Spill Conference, San Antonio, Texas, February, p. 303-306. 
Mills, M.J., 1992, "Alaska Sport Fishing in the Aftermath of the Exxon Valdez Oil Spill," Alaska Department of Fish and Game, Special Publication No. 92-5, 172 p.

NOAA (National Oceanic and Atmospheric Administration), 1993. "Natural Resource Damage Assessments Under the Oil Pollution Act of 1990," Advance Notice of Proposed Rulemaking, Federal Register, v. 58, no. 10, January 15, p. 4601-4614.

O'Brien, J.L., 1981. "National Strike Force Response IXTOC 1 Blowout -- Bay of Campeche," 1981 Oil Spill Conference Proceedings, Atlanta, Georgia, March 2-5, p. 125-130.

Oil and Gas Journal, 1993. "First Penalties Levied Under U.S. Oil Pollution Act," February 22, p. 44.

Plante, K.J., Barnett, E.L., Preble, D.J., and Price, L.M., 1993, "Florida's Pollutant Discharge Natural Resource Damage Assessment Compensation Schedule -- A Rational Approach to the Recovery of Natural Resource Damages," Proceedings of the 1993 International Oil Spill Conference, Tampa, Florida, March 29-April 1, 1993, p. 717-720.

Public Law 101-380, 1990. "Oil Pollution Act of 1990," 101st Congress, 104 Stat. 484.

Restrepo and Associates, 1982. "IXTOC 1 Oil Spill Economic Impact Study," report prepared for U.S. Bureau of Land Management, $16 \mathrm{p}$.

Robilliard, G.A., Fischel, M., Desvousges, W.H., Dunford, R.W., and Mathews, K., 1993, "Evaluation of Compensation Formulae to Measure Natural Resource Damages," Proceedings of the 1993 International Oil Spill Conference, Tampa, Florida, March 29April 1, 1993, p. 739-743.

Sauer T. and Boehm, P., 1991, "The Use of Defensible Analytical Chemical Measurements for Oil Spill Natural Resource Damage Assessment," Proceedings of the 1991 Oil Spill Conference, San Diego, March 4-7, p. 363-369.

State of Ohio v. Department of Interior, 1989. D.C. Circuit Court, 880 F.2d at 442 n.4.

Straughan, D., 969 . "The Santa Barbara Study, "Joint Conference on Prevention and Control of Oil Spalls, Proceedings, New York, December 15-17, p. 309-311.

Trustee Council, I, 1991. "The 1991 State/Federal Natural Resource Damage Assessment and Restoration Plan for the Exxon Valdez Oil Spill," April.

Waldichuk, M., 1980. "Retrospect of the IXTOC 1 Blowout," Marine Pollution Bulletin, vol. 11, p. 184-186.

Woods, E.G. and Hannah, R.P., 1981.

"IXTOC 1 Oil Spill -- The Damage Assessment Program and Ecological Impact," 1981 Oil Spill Conference Proceedings, Atlanta, Georgia, March 2-5, p. 439-443. 
Appendix 1

Oil Spills in U.S. Waters 1973 - 1990 


\begin{tabular}{|c|c|c|c|c|c|c|}
\hline DATE & VESSEL NAME & TYPE & STATE & $\begin{array}{l}\text { PRIMARY } \\
\text { OIL. TYPEE }\end{array}$ & CAUSE & $\begin{array}{l}\text { VOLUME } \\
\text { (GALLONS) }\end{array}$ \\
\hline 07 MAR 73 & HILLYER BROWN & TNKS & $\mathrm{AK}$ & OOD & GRD & 196,182 \\
\hline 09 MAR 73 & PC 2901 & TNKB & TX & OIL & $\mathrm{COL}$ & 420,000 \\
\hline 18 MAR 73 & ZOE COLOCO'TRONI & TNKS & PR & OIL & GRD & $1,505,910$ \\
\hline 09 APR 73 & PENNANT & TNKS & RI & GAV & GRD & 250,000 \\
\hline 03 JUN 73 & & TNKS & NY & OSX & $\mathrm{COL}$ & 840,000 \\
\hline 10 JUL 83 & & TNKB & LA & OIL & $\mathrm{COL}$ & 210,000 \\
\hline $01 \mathrm{DEC} 73$ & & TNKB & KY & OTW & $\mathrm{COL}$ & 153,690 \\
\hline 24 DEC 73 & & TNKB & MS & osx & $\mathrm{COL}$ & 105,000 \\
\hline 26 DEC 73 & & TNKS & PA & OIL & GRD & 126,000 \\
\hline 15 JAN 74 & & TNKB & LA & Oll & $\mathrm{COL}$ & 157,500 \\
\hline 19 FEB 74 & & TNKS & NJ & OSX & COL & 285,000 \\
\hline 15 APR 74 & IMPERIAL SORNEA & TNKS & NY & OIL & GPD & 147,000 \\
\hline 22 JUN 74 & & TNKB & LA & OIL & $\mathrm{COL}$ & $1,008,000$ \\
\hline 08 JUL 74 & TM 10 & TNKB & $\mathrm{TX}$ & OSX & $\mathrm{COL}$ & 378,000 \\
\hline 19 JUL 74 & HYGRADE & TNKB & NY & GAV & GRD & $13 c, 000$ \\
\hline 06 OCT 74 & & TNKS & $\mathrm{CT}$ & OSX & GRD & 105,000 \\
\hline 09 OCT 74 & & TNKS & TX & OIL & UNK & $306,00 ?$ \\
\hline 22 OCT 74 & & TNKS & LA & OSX & GRD & 103,026 \\
\hline 22 JAN 75 & MICHAEL C. LEMOS & TNKS & VI & OIL & GRD & 376,000 \\
\hline 31 JAN 75 & CORINTHOS & TNKS & PA & OIL & COL & 500,000 \\
\hline 03 MAR 75 & IOT-105 & TNKB & MS & GAT & $\mathrm{COL}$ & 840,000 \\
\hline 05 MAR 75 & & TNKB & MS & OIL & $\mathrm{COL}$ & 744,697 \\
\hline 05 MAR 75 & B-421 & TNKB & MS & OIL & $\mathrm{COL}$ & 111,881 \\
\hline 04 APR 75 & POLAR PARAGUAY & TNKS & & OSX & WTH & $6,000,000$ \\
\hline 25 APR 75 & & TNKB & LA & OIL & COL & 210,000 \\
\hline 15 AUG 75 & & TNKS & & OIL & $\mathrm{COL}$ & 840,000 \\
\hline 07 OCT 75 & B.NO. 115 & TNKB & NY & OFR & GRD & $102,000)$ \\
\hline 09 DEC 75 & $Z-102$ & T'NKB & PR & OSX & GRD & 322,518 \\
\hline 02 FEB 76 & STC-101 & TNKB & VA & OSX & FDP & 251,538 \\
\hline O8 FEB 76 & FLORIDA & TNKB & IL & JPO & GRD & 225,000 \\
\hline 24 FEB 76 & SJT 4 & TNKB & LA & OIL & COL & 159.768 \\
\hline $04 \mathrm{MAY} 76$ & N.M.S.NO. 3105 & TNKS & $\mathrm{TX}$ & OSX & UNK & 210,000 \\
\hline $19 \mathrm{MAY} 76$ & E17 & TNKB & $\mathrm{OH}$ & OSX & GRD & 126,000 \\
\hline 23 JUN 76 & NEPCO 140 & TNKB & NY & OSX & GRD & 307,000 \\
\hline 05 OCT 76 & SEALIFT PACIFIC & TNKS & $\mathrm{AK}$ & JPV & GRD & 395,670 \\
\hline $29 \operatorname{OCT} 76$ & & TNKB & NJ & OIL & $\mathrm{COL}$ & 277,200 \\
\hline 29 ОСТ 76 & RICHARD SAUER & TNKS & $\mathrm{PA}$ & OlL & GRD & 255,000 \\
\hline 15 DEC 76 & ARGO MERCHAN'T & TNKS & MA & OSX & GRD & $7,500,000$ \\
\hline 17 DEC 76 & & TNKS & $\mathrm{CA}$ & OSX & $\mathrm{CNC}$ & $1,000,000$ \\
\hline 28 DEC 76 & OLYMPIC GAMES & TNKS & $\mathrm{PA}$ & OIL & GRD & 133,000 \\
\hline 17 JAN 77 & IRENE'S CHALLENGE & TNKS & $\mathrm{HI}$ & OIL & FDR & $9,600,000$ \\
\hline 01 FI:B 77 & B.NO. 105 & TNKB & NJ & OSX & GRD & 100,000 \\
\hline 04 FEBB 77 & ETHEL, H & TNKB & NY & OSX & GRD & 420,000 \\
\hline
\end{tabular}




\begin{tabular}{|c|c|c|c|c|c|c|}
\hline DATE & VESSEL NAME & TYPE & STATE & $\begin{array}{l}\text { PRIMARY } \\
\text { OIL TYPE } \\
\end{array}$ & CAUSE & $\begin{array}{c}\text { VOLUME } \\
\text { (GALLONS) }\end{array}$ \\
\hline 25 JUN 77 & IOT-102 & TNKB & LA & osx & COL. & 157,920 \\
\hline 05 NOV 77 & MORANIA NO. 200 & TNKB & $\mathrm{NC}$ & ASR & GRD & $1,821,000$ \\
\hline 09 JAN 78 & $B-100$ & TNKB & NY & OOD & GRD & 210,000 \\
\hline 31 JAN 78 & DOMAR 6501 & TNKB & LA & OSX & $\mathrm{COL}$ & 252,000 \\
\hline 16 MAR 78 & OCEAN 250 & TNKB & RI & GAV & GRD & 682,458 \\
\hline 20 MAR 78 & INTERSTATE 19 & TNKB & $\mathrm{DE}$ & JPV & FIR & 630,000 \\
\hline 22 APR 78 & BGE 102 & TNKB & MO & OTW & $\mathrm{COL}$ & 210,000 \\
\hline 02 MAY 78 & MISSISSIPPI & TNKB & $M N$ & GRF & GRD & 124,195 \\
\hline 03 DEC 78 & ARIES/CAPRICORN & TNKS & $\mathrm{SC}$ & OSX & $\mathrm{A}^{\prime} T \mathrm{~T}$ & 600,000 \\
\hline 19 DEC 78 & DOMAR 118/PECK SLIP & TNKB & PR & OIL & WTH & 462,000 \\
\hline 28 JAN 79 & ESSO BAYWAY & TNKS & $\mathrm{TX}$ & OIL & ANC & 263,000 \\
\hline 17 MAR 79 & STCO-228 & TNKB & $\mathrm{TX}$ & GAV & COL & 168,000 \\
\hline 25 JUN 79 & INTERSTATE 50 & TNKB & PA & OIL & COL & 189,000 \\
\hline 01 SEP 79 & CHEVRON HAWAII & TNKS & TX & ORG & EXP & 750,000 \\
\hline 01 NOV 79 & BURMAH AGATE & TNKS & $\mathrm{TX}$ & OIL & $\mathrm{COL}$ & $2,389,800$ \\
\hline 19 DEC 79 & DONAU MARU & TNKS & MA & OSX & VLV & 264,810 \\
\hline $19 \mathrm{DEC} 79$ & PINA & TNKS & LA & OIL & RAM & 168,000 \\
\hline 25 DEC 79 & LEE WANG ZIN & TNKS & $\mathrm{AK}$ & OIL & CAP & 370,000 \\
\hline 17 JAN 80 & NEW YORK & TNKB & FL & GAT & GRD & 138.000 \\
\hline 23 FEB 80 & OCEAN CITIES & TNKB & L.A & GAV & $\mathrm{COL}$ & 210,000 \\
\hline 16 MAR 80 & HBL 3011 & TNKB & LA & OIL & $\mathrm{COL}$ & 378,000 \\
\hline 27 APR 80 & HAN CHEONG & TNKB & GU & ORG & NEC & 400,000 \\
\hline 29 APR 80 & STCO 227 & TNKB & $\mathrm{TX}$ & ORG & $\mathrm{COL}$ & 168,000 \\
\hline 25 JUL 80 & EXXON HOUSTON & TNKS & LA & OOD & $\mathrm{COL}$ & 120,000 \\
\hline 21 NOV 80 & CHRISTIAN F. REINAUER & TNKS & $\mathrm{ME}$ & OCF & GRD & 100,000 \\
\hline 22 NOV 80 & GEORGIA & TNKS & LA & OIL & ANC & $1,344,000$ \\
\hline $24 \mathrm{DEC} 80$ & ТT 7002 & TNKB & $\mathrm{TX}$ & GAC & TOP & 138,000 \\
\hline 06 JAN 81 & CHOTIN 2880 & 'T'NKB & KY & GAV & $\mathrm{COL}$ & 100,000 \\
\hline 28 JAN 81 & OLYMPIC GLORY & TNKS & $T X$ & OIL & $\mathrm{COL}$ & $1,000,000$ \\
\hline $19 \mathrm{MAR} 81$ & APEX HOUSTON & TNKB & LA & OSX & COL & $3,738,000$ \\
\hline 04 SEP 81 & APHRODITE B & TNKS & LA & OTW & $\mathrm{COL}$ & 360,000 \\
\hline 31 MAR 82 & ARKAS & TNKS & LA & OlL & $\mathrm{COL}$ & $1,051,000$ \\
\hline 27 JUN 82 & APEX 2904 & TNKB & AR & OsX & GRD & 336,000 \\
\hline 23 JUL 82 & BARGE 450-3 & TNKB & LA & GAT & GRD & 210,000 \\
\hline 02 APR 83 & V-884 & TNKB & MO & OlL & $\mathrm{COL}$ & 227,262 \\
\hline 09 JUN 83 & SFI $71 \&$ SFI 72 & TNKB & MS & OSX & RAM & 590,000 \\
\hline 25 SEP 83 & MATTHEW/EX. CHRISTINA F & TNKB & NY & GAV & GRD & 240,000 \\
\hline 25 DEC 83 & BARGE 218 & TNKB & LA & OOD & COL & 105,000 \\
\hline 22 JAN 84 & CEPHEUS & 'TNKS & $\mathrm{AK}$ & KRS & GRD & 200,000 \\
\hline 25 FEB 84 & AMERICAN EAGLE & INNKS & LA & OIL & $\mathrm{COL}$ & $168,000)$ \\
\hline 25 FEB 84 & CHEM 102 & TNKB & LA & OMS & $\mathrm{COL}$ & 412,860 \\
\hline 19 MAR 84 & MOBIL OIL & TNKS & OR & $\mathrm{OCF}$ & GRD & 168,126 \\
\hline
\end{tabular}




\begin{tabular}{|c|c|c|c|c|c|c|}
\hline DATF & VESSEL NAME & TYPE: & STATE & $\begin{array}{l}\text { PRIMARY } \\
\text { OIL. TYPEE } \\
\end{array}$ & CAUSE & $\begin{array}{c}\text { VOL.UME } \\
\text { (GALLONS) } \\
\end{array}$ \\
\hline 02 MAY 84 & OFFSHORE 2403 & 'TNKB & CA & JPV & UNK & 119,952 \\
\hline 30 JUL 84 & ALVENUS & TNKS & LA & OIL & GRD & $2,757,258$ \\
\hline 20 OCT 84 & CHEM 13 & TNKB & MO & O'TW & GRD & 110,000 \\
\hline 31 OCT 84 & PUERTO RICAN & TNKS & $\mathrm{CA}$ & $\mathrm{OCF}$ & EXP & $1,250,000$ \\
\hline $16 \mathrm{DEC} 84$ & & TNKB & $\mathrm{TX}$ & GAV & UNK & 229,000 \\
\hline 12 FEB 85 & BW 1933 & TNKB & TN & JPV & COL & 168,000 \\
\hline 23 MAY 85 & CHOTIN 1451 & 'TNKB & LA & NSW & RAM & 109,200 \\
\hline 18 AUG 85 & EXXON BARGE NO. 32 & TNKB & VA & OTW & UNK & $1,260,000$ \\
\hline 29 SEP 85 & AMERSHAM/GRAND EAGLE & TNKS & PA & OIL & GRD & 435,000 \\
\hline 24 NOV 85 & SFI-41 & TNKB & & OSX & $\mathrm{COL}$ & 705,600 \\
\hline 16 DEC 85 & B.NO. 145 & TNKB & $\mathrm{TX}$ & GSR & MNT & 115,500 \\
\hline 17 DEC 85 & DXE 3006 & TNKB & IL & OlL & $\mathrm{COL}$ & 180,600 \\
\hline 21 DEC 85 & ARCO ANCHORAGE & 'TNKS & WA & OlL & GRD & 238,980 \\
\hline 07 MAR 86 & TEXAS & TNKB & IL & OIL & GRD & 716,310 \\
\hline $21 \mathrm{MAR} 86$ & INTERMAR ALLIANCE & TNKS & PA & OIL & COL & 105,000 \\
\hline 31 JUL 86 & $\operatorname{TTT} 103$ & TNKB & & OTW & EXP & 622,440 \\
\hline 10 SEP 86 & VIKING OSPREY & TNKS & NJ & Oll & GRD & 264,600 \\
\hline 17 SEP 86 & S.T. 85 & T'NKB & $\mathrm{MA}$ & GA'T & GRD & 119,762 \\
\hline 27 OCT 86 & IB $2003 \mathrm{~L}$ & TNKB & MO & (iAT & $\mathrm{COL}$ & 122,052 \\
\hline 16 NOV 86 & AMAZON VENTURE & TNKS & NY & OSX & VLV & 105,706 \\
\hline 04 DEC 86 & AMAZON VENTURE & TNKS & GA & os $x$ & VLV & 500,000 \\
\hline 15 JAN 87 & STUYVESANT & TNKS & & OIL & W'TH & 588,336 \\
\hline 17 FEB 87 & TEXACO 807 & TNKB & NY & OTD & NEC & 301,770 \\
\hline 04 OC'T 87 & STUYVESANT & TNKS & $\mathrm{AK}$ & OIL & WTH & 914,928 \\
\hline 17 JAN 88 & DOMAR 115 & TNKB & MS & GAT & GRD & 294,000 \\
\hline 13 JUL 88 & NORD PACIFIC & TNKS & $\mathrm{TX}$ & OIL & RAM & 644,700 \\
\hline 24 AUG 88 & 565 & TNKB & VA & ODS & WTH & 211,974 \\
\hline 05 SEP 88 & EXXON BARGE 503 & TNKB & FL & O'TD & UNK & 126,168 \\
\hline $23 \mathrm{DEC} 88$ & NESTUCCA & 'INKB & WA & OSX & $\mathrm{COL}$ & 227,304 \\
\hline 26 DEC 88 & UM'TB 283 & TNKB & $\mathrm{AK}$ & OTD & UNK & $2,041,662$ \\
\hline 24 MAR 89 & EXXON VALDI:Z & TNKS & $\mathrm{AK}$ & OIL & (iRD) & $10,500,000$ \\
\hline 23 JUN 89 & COASTAL 2514 & TNKB & $\mathrm{TX}$ & osx & $\mathrm{COL}$ & 252,000 \\
\hline 23 JUN 89 & WORLD PRODIGY & TNKS & RI & OTW & GRD & 292,000 \\
\hline 24 JUN 89 & PRESIDENTE RIVI:RA & TNKS & PA & OSX & GRD & $307,000)$ \\
\hline 07 FEB 90 & AMERICAN TRADER & TNKS & $\mathrm{CA}$ & OIL. & ANC & 397,236 \\
\hline 06 MAR 90 & CIBRO SAVANN.IH & 'TNKB & NJ & OTW & $\mathrm{COI}$ & 126,000 \\
\hline 07 JUN 90 & B'T NAU'TILUS & TNKS & NJ & os $x$ & GRI) & 250,000 \\
\hline 09 JUN 90 & MEGA BORC; & TNKS & & OIL & EXP & 400,000 \\
\hline 28 JUL. 90 & APLXX 3417 & TNKB & $\mathrm{TX}$ & OFV & COL & 654,864 \\
\hline $19 \wedge \cup G 90$ & OCEAN 192 & 'TNKB & DE: & GAT & COL & 152,000 \\
\hline 16 SEP 90 & JUPIITER & 'INKS & MI & (IATT & EXP & 316,680 \\
\hline 26 OCT 90 & HYGRADE 42 & TNKB & NY & KRS & $\mathrm{COL}$ & 164,000 \\
\hline
\end{tabular}



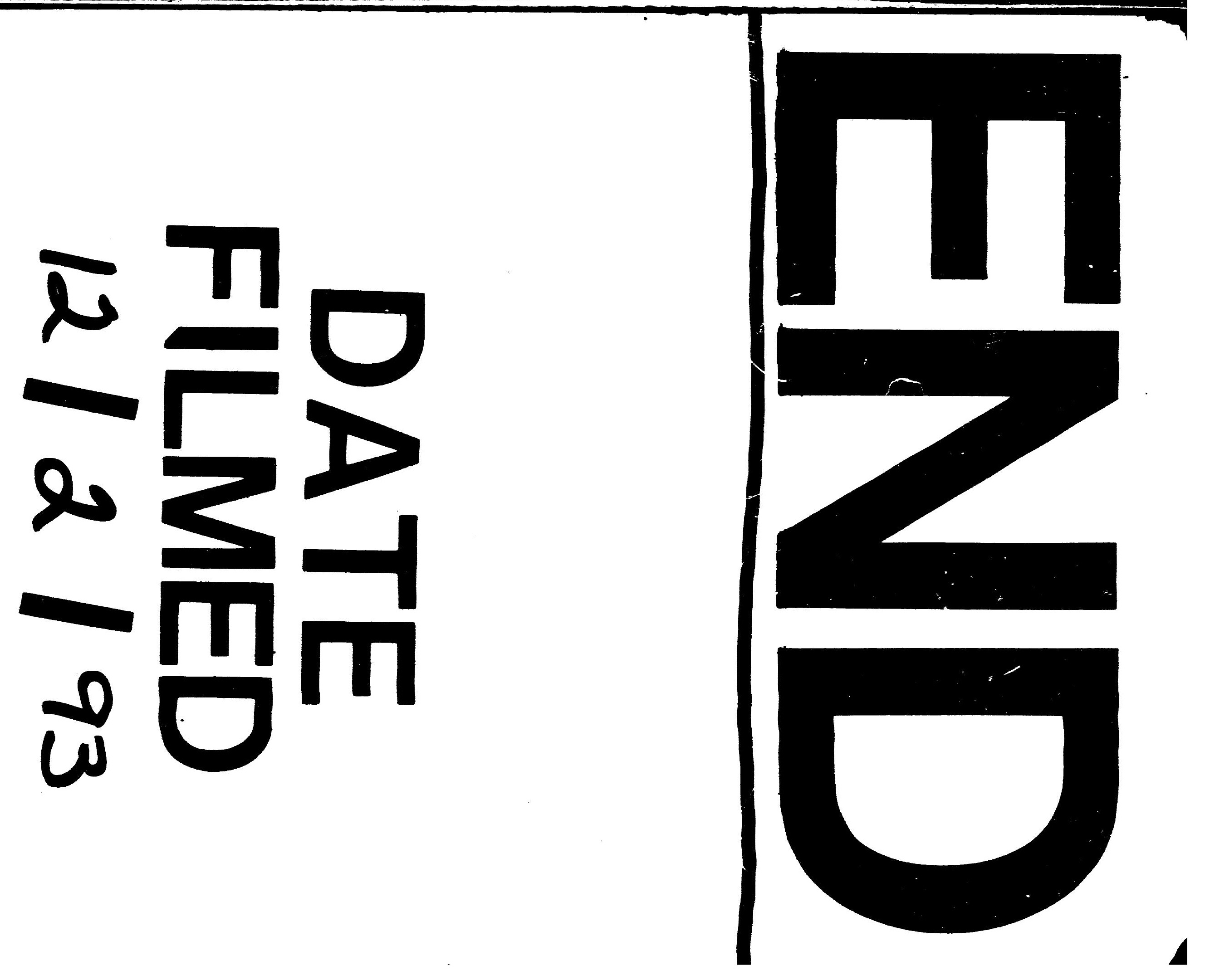
